\title{
BORO E ESTRESSE HÍDRICO NA NUTRIÇÃO E PRODUÇÃO DO GIRASSOL EM CASA-DE-VEGETAÇÃO
}

\author{
CESAR DE CASTRO \\ Engenheiro Agrônomo
}

Orientador: Prof. Dr. ANTONIO ROQUE DECHEN

Tese apresentada à Escola Superior de Agricultura "Luiz de Queiroz", Universidade de São Paulo, para obtenção do título de Doutor em Agronomia, Área de Concentração: Solos e Nutrição de Plantas.

PIRACICABA

Estado de São Paulo - Brasil

Abril -1999 


\section{Dados Internacionais de Catalogação na Publicação (CIP) DIVISÃO DE BIBLIOTECA E DOCUMENTAÇÃO - Campus "Luiz de Queiroz"/USP}

\section{Castro, Cesar de}

Boro e estresse hidrico na nutrição e produção do girassol em casa-devegetação / Cesar de Castro. - - Piracicaba, 1999.

120 p. : il.

Tese (doutorado) - - Escola Superior de Agricultura Luiz de Queiroz, 1999. Bibliografia.

1. Boro 2. Cultivo em vaso 3. Estresse hidrico 4. Estufa 5. Girassol 6. Nutriçāo vegetal I. Titulo

CDD 633.39

"Permitida a copia total on parcial leste documento, desde que citada a fonte - $O$ A utor" 
AOS MEUS PAIS

José de Castro Júnior e

Zolima da Conceição de Castro

\title{
OFEREÇO
}

A minha esposa

Luci Keiko Kuromoto de Castro e aos nossos filhos

Igor Kuromoto de Castro e

Natasha Kuromoto de Castro

\author{
DEDICO
}




\section{AGRADECIMENTOS}

Ao Prof. Dr. Antonio Roque Dechen pela orientação, amizade e confiança demonstrada;

À EMBRAPA, através do Centro Nacional de Pesquisa de Soja pela oportunidade de realização do curso;

À Escola Superior de Agricultura "Luiz de Queiroz"-USP pela oportunidade oferecida;

Ao Conselho Nacional de Pesquisa e Desenvolvimento Científico e Tecnológico (CNPq) pela bolsa de estudo concedida;

Ao Prof. Dr. Ricardo Ferraz de Oliveira pela convivência, amizade, confiança e cessão da infra-estrutura do Horto Experimental do Departamento de Ciências Biológicas da ESALQ-USP;

Aos Professores Álvaro Pires da Silva, Antônio Sanches de Oliveira, Décio Barbin, Euripedes Malavolta, Francisco Antonio Monteiro, Frederico Pimentel Gomes, José Carlos Chitolina, Klaus Reichardt, Murilo Mello, Osni e Quirino Augusto de Camargo Carmelo pelas sugestões oferecidas;

A todos os demais professores do Curso de Solos e Nutrição de Plantas pela oportunidade e conhecimentos transmitidos;

Aos pesquisadores Clóvis Manoel Borkert e Gedi Jorge Sfredo pelas sugestões, amizade e incentivo;

Aos funcionários do Laboratório de Análises Químicas de Solo e tecido Vegetal do CNPSo e do Laboratório de Análises de Solo do Setor de Nutrição de Plantas do Departamento de Solos e Nutrição de Plantas da ESALQ-USP

Aos funcionários da Biblioteca Central da ESALQ-USP pelo atendimento e dedicação;

Aos funcionários do Restaurante Universitário pelo atendimento e dedicação; 
Aos Amigos Aderbal Rocha, Adônis Moreira, Alberto Bernardi, Alcebíades São Jorge, Ana Rosa, Antônio Sampaio, Carla Rossi, Eli Oliveira, Fábio Alvares, Gláucia Regina, Jaílson Fagundes, João Batista, Jonas Ruschel, Linda Mônica, Luiz Timm, Marcela Miller, Quelmo Novaes, Reginaldo Barros, Reynaldo Beltrán, Reges Heinrichs, Robinson Andrade e Simone Melo pela amizade e convivência;

A todos os demais que direta ou indiretamente contribuíram para a realização deste trabalho. 


\section{SUMÁRIO}

Página

RESUMO vii

SUMMARY ix

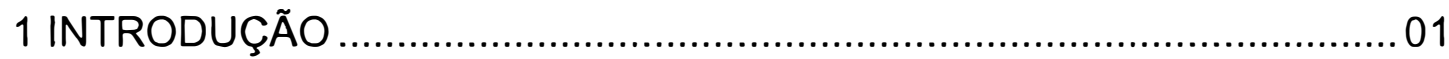

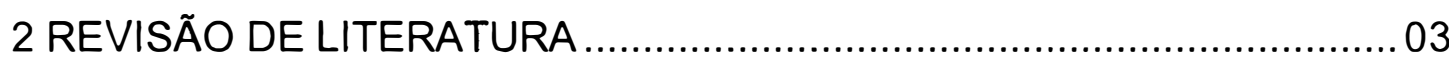

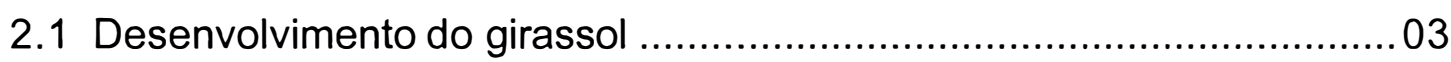

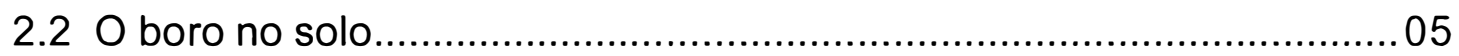

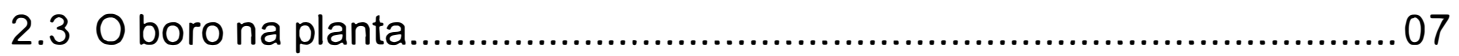

2.4 Exigências nutricionais em boro na cultura do girassol ........................ 10

2.5 Exigências hídricas da cultura do girassol ......................................... 14

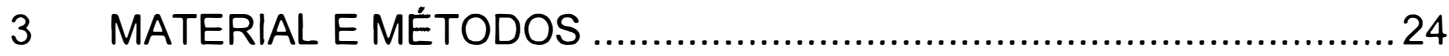

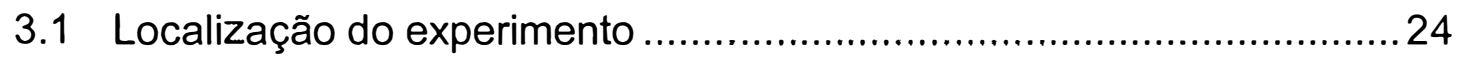

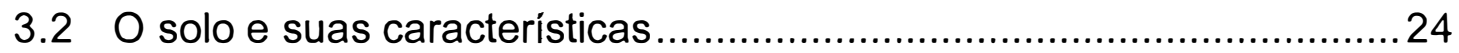

3.3 Genótipos de girassol .................................................................... 25

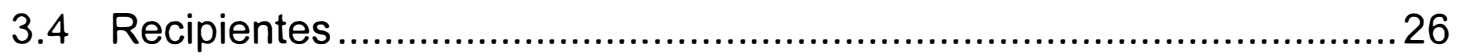

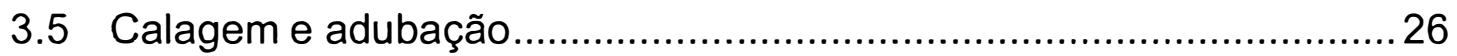

3.6 Delineamento experimental e análise estatística..............................29

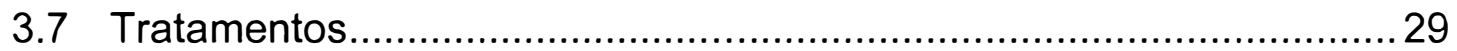

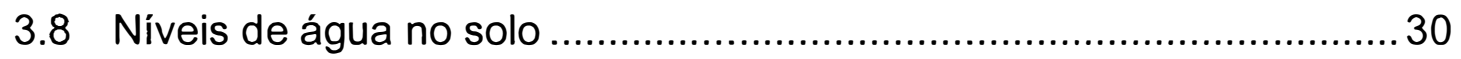

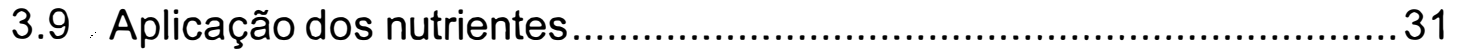

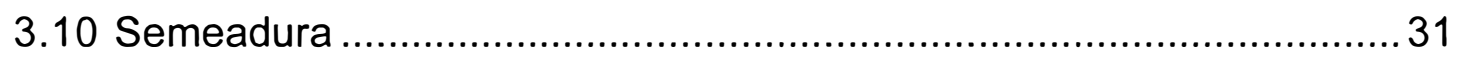

3.11 Monitoramento e controle da umidade do solo .................................31

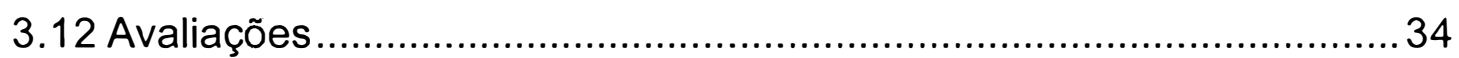

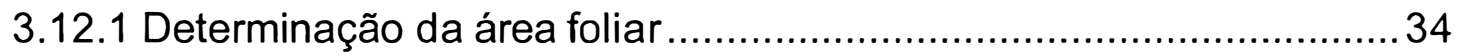

3.12.2 Determinação da matéria seca de plantas e rendimento de aquênio 35

3.12.3 Determinação da altura das plantas ................................................ 35 


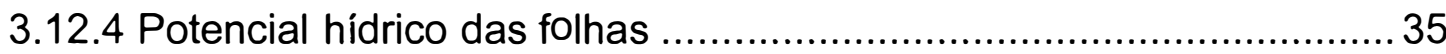

3.12.5 Monitoramento da radiação fotossinteticamente ativa ..................... 36

3.12.6 Análise química do material vegetal ............................................ 36

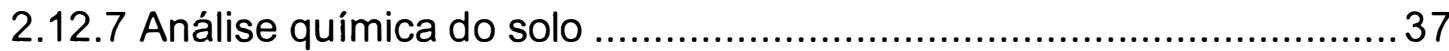

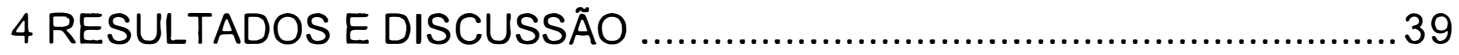

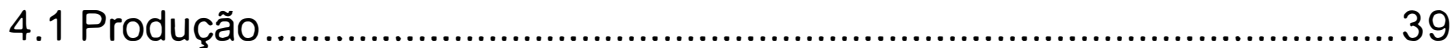

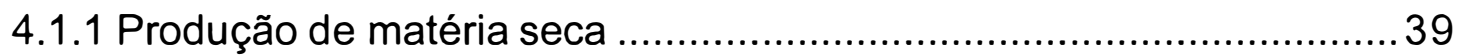

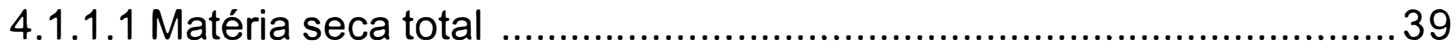

4.1.1.2 Matéria seca da parte aérea...................................................... 42

4.1.1.3 Matéria seca de raiz ................................................................... 44

4.1.1.3.1 Relação matéria seca de raiz e matéria seca da fitomassa total... 45

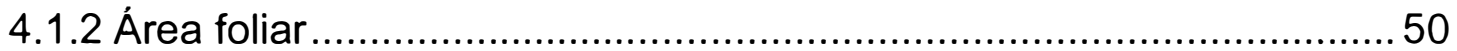

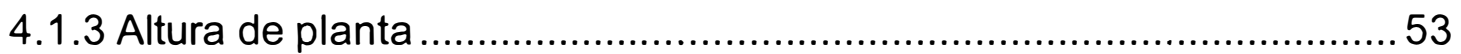

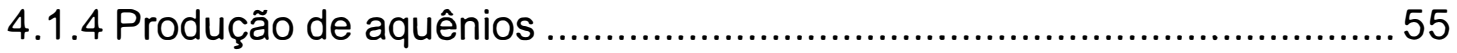

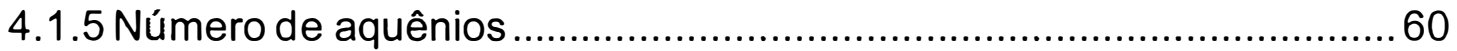

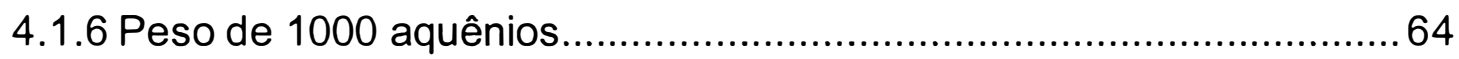

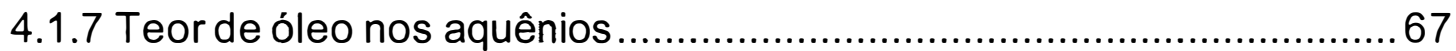

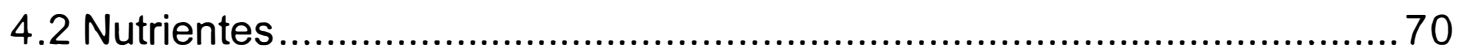

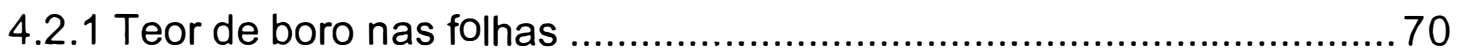

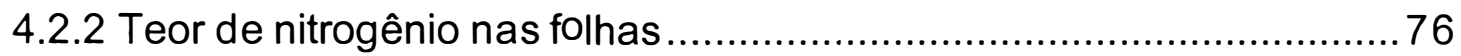

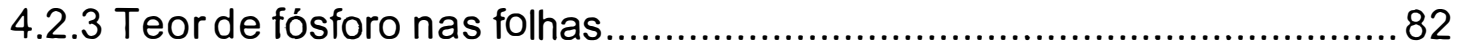

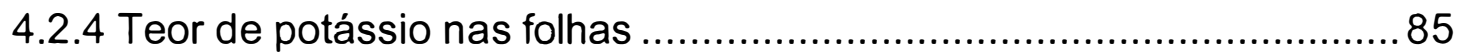

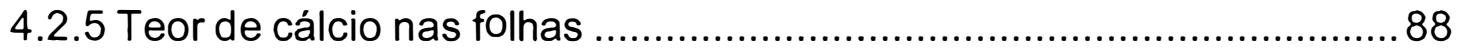

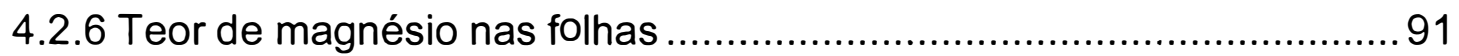

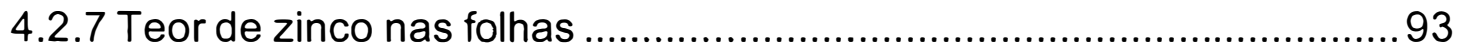

4.2.8 Teor de manganês nas folhas .......................................................... 94

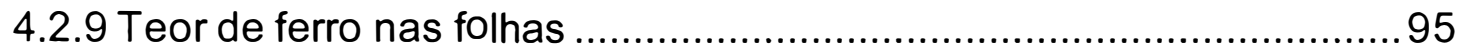

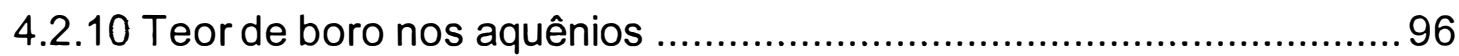

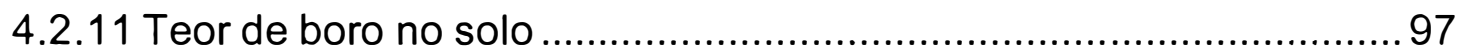


5 CONCLUSÕES

REFERÊNCIAS BIBLIOGRÁFICAS. 101 APÊNDICE . 


\title{
BORO E ESTRESSE HÍDRICO NA NUTRIÇÃO E PRODUÇÃO DO GIRASSOL EM CASA-DE-VEGETAÇÃO
}

\author{
Autor: CESAR DE CASTRO \\ Orientador: Prof. Dr. ANTONIO ROQUE DECHEN
}

\section{RESUMO}

Este trabalho foi desenvolvido em casa de vegetação localizada no Horto Experimental do Departamento de Ciências Biológicas da Escola Superior de Agricultura "Luiz de Queiroz" e teve por objetivo estudar o efeito da interação entre doses de boro aplicadas ao solo e fases de aplicação de estresse hídrico na produção e nutrição do girassol.

As plantas de girassol foram cultivadas em vasos contendo $10 \mathrm{~kg}$ de um latossolo vermelho amarelo distrófico de textura média, fase cerradão, coletado no município de São Carlos - SP. Utilizou-se o delineamento experimental de blocos completos ao acaso, em esquema fatorial, $4 \times 4$ (quatro doses de boro e quatro fases de controle de umidade no solo) com quatro repetições. As doses de boro foram: 0,$0 ; 0,25 ; 0,5$ e 2,0 $\mathrm{mg} \mathrm{kg}^{-1}$ de $\mathrm{B}$, na forma de ácido bórico. As fases de controle de umidade foram: sem estresse hídrico durante o ciclo (SEM), com estresse hídrico durante o ciclo (COM), estresse hídrico a partir do início de florescimento (IFL) e estresse hídrico a partir do início de enchimento de aquênios (IEA). A saturação por bases foi corrigida para $60 \%$, aplicando-se em todos os tratamentos $\mathrm{N}, \mathrm{P}, \mathrm{K}, \mathrm{Ca}, \mathrm{Mg}$ e $\mathrm{S}$, e os micronutrientes $\mathrm{Zn}, \mathrm{Fe}, \mathrm{Cu}$, Mn e Mo.

As análises de tecido para as determinações de macro e micronutrientes foram realizadas utilizando-se a folha mais jovem fisiologicamente madura e a folha localizada imediatamente acima e abaixo, coletadas no início do florescimento. Os parâmetros de produção foram obtidos durante a condução do experimento até a colheita, determinado-se: matéria seca da parte aérea e das raízes, área foliar, altura de planta, produção, número e teor de óleo de 
aquênios e peso de 1000 aquênios. Ao final do experimento foram determinados os teores de boro no solo de cada tratamento.

As doses de boro apresentaram efeito positivo sobre todos os parâmetros de produção avaliados, bem como no teor de boro das folhas e do solo, em todas as fases de aplicação do estresse hídrico, enquanto estas influenciaram distintamente todos os parâmetros estudados. As plantas do tratamento SEM proporcionaram os maiores componentes de produção. $O$ estresse hídrico nos tratamentos COM, IFL e IEA, afetou negativamente a produção de matéria seca da parte aérea e da raiz, a produção, número e rendimento de óleo de aquênios e o peso de 1000 aquênios.

As plantas do tratamento COM apresentaram os maiores teores de nutrientes no tecido foliar; entretanto, em função do menor desenvolvimento das mesmas houve menor acúmulo de nutrientes e obtidos os menores componentes de produção. A área foliar das plantas dos tratamentos COM e IFL foi seriamente reduzida pelo estresse hídrico.

O estresse hídrico aplicado a partir do início do florescimento e do enchimento de aquênios proporcionou menor rendimento de aquênios, demonstrando que estes estádios fenológicos são de elevada sensibilidade ao estresse hídrico.

A obtenção de $90 \%$ da produção máxima de aquênios foi conseguida quando os teores de boro no solo estavam entre 0,46 e $0,51 \mathrm{mg} \mathrm{kg}^{-1}$ e nas folhas entre 42 a $43 \mathrm{mg} \mathrm{kg}^{-1}$. 


\title{
BORON AND WATER STRESS EFFECTS ON YIELD AND NUTRITION OF SUNFLOWER GROWN IN GREENHOUSE CONDITIONS
}

\author{
Author: Cesar de Castro \\ Adviser: Antonio Roque Dechen
}

\section{SUMMARY}

This work was carried out in a greenhouse, in Piracicaba, SP, Brazil, with the objective of studying the effect of the interaction between boron rates applied to the soil and phases of water stress, on the yield and the nutrition of sunflower.

Plants were cultivated in plastic pots with $10 \mathrm{~kg}$ of a distrophic yellow-red latosol, of medium texture, phase "cerradão", sampled in the county of São Carlos, SP, Brazil. The experimental design consisted of blocks, in a factorial scheme, with 16 treatments (four B levels and four soil water content control phases) with four replicates. The $B$ rates were: $0.0 ; 0.25 ; 0.5$ and $2.0 \mathrm{mg} \mathrm{kg}^{-1}$, in the boric acid form.

The soil water content levels were: without water stress for the whole cycle (SEM), with water stress during the whole cycle (COM), with water stress after beginning of flowering (IFL) and with water stress after beginning grain filling (IEA).

Soil base saturation was corrected to $60 \%$ with calcium and magnesium carbonate. All treatments received uniform fertilization consisting of $\mathrm{N}, \mathrm{P}, \mathrm{K}, \mathrm{Ca}$, $\mathrm{S}$ and the micronutrients $\mathrm{Zn}, \mathrm{Fe}, \mathrm{Cu}, \mathrm{Mn}$ and $\mathrm{Mo}$.

Tissue contents of $\mathrm{N}, \mathrm{P}, \mathrm{K}, \mathrm{Ca}, \mathrm{Mg}, \mathrm{B}, \mathrm{Zn}, \mathrm{Fe}, \mathrm{Cu}, \mathrm{Mn}$, and $\mathrm{Mo}$ were performed using the youngest leaf at physiological maturity, and the leaf immediately above and below, all collected at the beginning of flowering (65 days after emergence). Yield data were observed during the whole experimental 
period, up to the harvest, which occured 102 days after emergence. The following parameters were evaluated: total dry matter, shoot dry matter, root dry matter, leaf area, plant height, yield, number and oil content of achenes, and weight of 1000 achenes. At the end of the experiment, soil boron content was determined for all treatments.

The boron rates presented a positive effect, in general way, on all studied parameters, as well as in the boron contents of leafs and soil, in all water stress phases, although influencing distinctly all studied parameters.

The water stress affected more severely the treatments COM, IFL and IEA affecting negatively the total dry matter, yield, that of shoot and root, the number and oil content of achenes, and weight of 1000 achenes.

The treatment COM presented, in a general way, the greatest value of nutrient content in leafs, however, due to the reduced plant development values were observed. The leaf area of the and treatments was severely reduced due to water stress.

IFL and IEA presented a lower achene yield, indicating that these phenologic stages of the crop are of extreme sensitivity for water lack.

Ninety percent of the maximum yield of achenes was obtained when the soil and leaf boron content were 0.46 to $0.51 \mathrm{mg} \mathrm{kg}^{-1}$, and 42 to $43 \mathrm{mg} \mathrm{kg}^{-1}$, respectively. 


\section{INTRODUÇĀO}

O girassol (Helianthus annuus L.) é uma dicotiledônea anual da família Compositae, originária do continente Norte Americano e cultivado nos cinco continentes, em aproximadamente 18 milhões de hectares. Destaca-se como a quarta oleaginosa para produção de grãos e a quinta em área cultivada no mundo. No Brasil, seu cultivo não ocupa áreas expressivas, porém, seu óleo tem boa aceitação, sendo seu consumo de mesa menor apenas que o de soja.

Segundo Gómez-Arnau (1988), o girassol tem um comportamento aparentemente contraditório quanto as relações hídricas. Sua eficiência no uso da água é muito baixa, sendo que para cada metro cúbico de água consumido, produz somente dois a três quilogramas de matéria seca frente a quatro e sete quilogramas, no caso da soja e do sorgo, respectivamente. É uma planta que em condições adequadas de umidade no solo tem alta perda de água por transpiração. Por isso, suas necessidades totais para expressar o potencial máximo produtivo são elevadas, em torno de 500 a $650 \mathrm{~mm}\left(5.000\right.$ a $6.500 \mathrm{~m}^{3}$ $\left.\mathrm{ha}^{-1}\right)$. Entretanto, esta baixa eficiência no uso da água melhora muito em condições de estresse hídrico, nas quais a eficiência relativa pode aumentar de 20 a $50 \%$ pois sua fotossintese reduz-se comparativamente menos que as perdas por transpiração.

O girassol é exigente em boro, apresentando com freqüência, nas principais regiões agrícolas do país, sintomas de deficiência do nutriente, principalmente nas fases de florescimento e maturação. As deficiências ocorrem principalmente em solos onde foram efetuadas aplicações recentes de doses elevadas de calcário, em solos com baixos teores de matéria orgânica e 
em solos arenosos e, principalmente em períodos de estresse hídrico, como o que normalmente ocorre no final do ciclo de produção do girassol em safrinha na Região do Cerrado.

Em condição de campo, observa-se com freqüência diversos sintomas de deficiência de boro, desde folhas com bronzeamento característico até queda de capítulos. Os baixos teores de boro no solo nas principais regiões agrícolas, associados principalmente ao estresse hídrico, acentuam a redução da disponibilidade de $\mathrm{B}$ no solo, ocasionando queda de produtividade da cultura. Não há dúvidas de que a disponibilidade da água no solo é fator essencial ao desenvolvimento das culturas e portanto, o planejamento de produção, em função da época de plantio, deve objetivar atender as principais fases críticas da cultura, à disponibilidade hídrica.

No Estado de Goiás o plantio do girassol é freqüentemente efetuado após a colheita da soja ou do milho (safrinha), sendo o periodo mais indicado, situado entre 15 de fevereiro e 15 de março, como sendo aquele que possibilita as melhores produções. Plantios além dessa época aumenta a probabilidade da coincidência do florescimento ou enchimento de aquênios com o término das chuvas, intensificando os problemas de carência de boro, em época crítica de produção de aqüênio e/ou óleo.

Graças às características de adaptabilidade em diversas regiões, apresenta-se como uma opção nos sistemas agrícolas implantados de rotação e sucessão de culturas nas regiões produtoras de grãos, já que existem espaços físicos temporais e/ou agronômicos, que podem ser ocupados para estabelecer sistemas mais diversificados.

O trabalho teve como objetivos estudar o efeito da interação entre doses de boro e fases de aplicação de estresse hídrico no desenvolvimento e estado nutricional da planta de girassol, cultivada em vasos, em casa-de-vegetação. 


\section{REVISÃO DE LITERATURA}

\subsection{Desenvolvimento do girassol}

A germinação do girassol é grandemente influenciada pela temperatura. Macchia et al. (1985) relatam que a taxa de germinação aumenta exponencialmente na faixa de 3 a $30^{\circ} \mathrm{C}$ e que a percentagem máxima de germinação é mantida de 6 a $23^{\circ} \mathrm{C}$. A germinação declina rapidamente acima de $25^{\circ} \mathrm{C}$, enquanto temperaturas entre 37 e $40^{\circ} \mathrm{C}$ danificam severamente as sementes e impedem a germinação (Macchia et al., 1985 e Maeda \& Ungaro, 1985).

O girassol caracteriza-se por um crescimento vagaroso nos primeiros 30 dias após a emergência, atingindo altura aproximada de $30 \mathrm{~cm}$ neste período. Durante os próximos 30 dias a altura das plantas quadruplica alcançando seu máximo ao redor dos 70 a 80 dias após a emergência (Unger, 1990).

Da emergência até em torno de 30 dias (aparecimento do botão floral) 0 crescimento do girassol é lento, consumindo pouca água e nutrientes. A partir desse período até o final do florescimento, o crescimento é rápido, aumentando o consumo de água e nutriente. Portanto, é neste período que a cultura é mais seriamente afetada, prejudicando significativamente $o$ rendimento.

Segundo Gachon (1972), 66\% do nitrogênio, fósforo e cálcio, $75 \%$ do potássio e $90 \%$ do magnésio são absorvidos no período de 30 dias antes e 30 dias após o início do florescimento.

A cultura do girassol pode produzir em torno de 10 a $15 \mathrm{Mg} \mathrm{ha}^{-1} \mathrm{de}$ matéria seca, notando-se que o índice de colheita (matéria seca de 
grãos/matéria seca total) é pequeno, de 0,25 a 0,30 em média, enquanto que na cultura do trigo este índice é de 0,5 a 0,6. Na avaliação do índice de colheita, devemos levar em consideração que a produção de aquênios exige maior custo energético que os grãos de trigo.

Merrien (1992) cita que a planta de girassol tem um sistema radicular com forte taxa de crescimento no início do ciclo, com maior participação que a parte aérea, com sua biomassa representando 20 a $30 \%$ da biomassa total. Porém, ao longo do ciclo, com a evolução do desenvolvimento da parte aérea, da sua biomassa representa, em torno de $15 \%$.

Para Connor \& Sadras (1992) três estádios são considerados na formação da produção. Primeiro, é o período do início do florescimento ao início da antese, quando as flores se diferenciam e se desenvolvem. $O$ segundo período está compreendido entre o início e o final da antese, quando o número de sementes é determinado a partir do número de flores viáveis capazes de se desenvolver e o terceiro, entre o final da antese e a maturação fisiológica, quando as condições de crescimento determinam o enchimento dos aquênios.

O período em que ocorre maior taxa de absorção de nutrientes e crescimento mais acelerado da planta de girassol é a fase imediatamente após a formação do botão floral até o final do florescimento (Sfredo et al.,1984 e Gutterres et al., 1988). Neste período também é grande o consumo de água pelas plantas, sendo, portanto, importante o suprimento adequado de nutrientes para que a cultura do girassol possa expressar todo seu potencial produtivo.

Comparado com outras culturas, a de girassol tem uma alta exigência pelo boro e, por esta razão tem sido usada como uma planta teste para avaliar a disponibilidade deste nutriente no solo (Schuster \& Stephenson, 1940).

As exigências nutricionais do girassol são relativamente elevadas quando comparadas às do milho para $\mathrm{N}$ e $\mathrm{P}$, e muito maiores para $\mathrm{K}$, $\mathrm{Ca}$ e $\mathrm{Mg}$. 
$\mathrm{Na}$ colheita mecanizada, que possibilita a retirada exclusiva dos grãos, ocorre retorno de maior quantidade de palha ao solo fazendo com que a exportação de nutrientes assemelhe-se a do milho (Gutterres et al., 1988)

Cox \& Jolliff (1987), trabalhando com girassol em condições de campo observaram que o girassol utilizava principalmente a água armazenada no solo entre 0,9 e 1,8m de profundidade, resultando na maior capacidade da cultura em extrair água em profundidade, propiciando menor restrição hídrica mesmo sob condições severas de seca durante o florescimento, estádio crítico ao déficit hídrico. Os mesmos autores concluíram que o girassol responde a seca através da redução da área foliar e extração de água em maior profundidade no perfil. Ambas respostas possibilitam a cultura a tolerar condições de secamento do solo, com um teor relativamente alto de água na planta. Esta característica é altamente favorável e contribui para o sucesso da cultura em condição de baixa precipitação como às do Brasil Central, na "safrinha". Por outro lado, para externar esta característica é também necessário que seu desenvolvimento não seja afetado por fatores químicos e físicos do solo. As raízes do girassol são vigorosas, porém são muito sensiveis a compactação e ao adensamento do solo, além das formas tóxicas de alumínio.

A profundidade do sistema radicular da cultura do girassol não é importante onde há adequado suprimento de água no solo. Sob condições de irrigação limitada, o aprofundamento do sistema radicular tem importante significado para que a cultura apresente rendimentos favoráveis (Unger, 1990).

\subsection{0 boro no solo}

O boro é o único nutriente que está presente normalmente na solução do solo como uma molécula não dissociada, na faixa de $\mathrm{pH}$ adequada ao desenvolvimento das plantas. $\mathrm{O} \mathrm{pK}_{1}$ do ácido bórico é 9,14; consequentemente, em pH 8 a fração de $\mathrm{H}_{2} \mathrm{BO}_{3}{ }^{-}$é menor que $10 \%$ e em pH 7 é menor que $1 \%$ (Oertli \& Grgurevic, 1975). 
O boro ocorre no solo em quatro principais formas: em rochas e minerais, adsorvido na superfície de argilas e sesquióxidos, em ligações com a matéria orgânica e como ácido bórico $\left(\mathrm{H}_{3} \mathrm{BO}_{3}\right)$ e $\mathrm{B}(\mathrm{OH})_{4}{ }^{-}$na solução do solo. $\mathrm{A}$ relação entre essas formas determinam a sua disponibilidade no solo e também sua absorção pelas plantas (Kumar et al., 1993).

A disponibilidade do boro no solo e seu aproveitamento pelas plantas é influenciado por diferentes fatores tais como textura do solo, $\mathrm{pH}$, condutividade elétrica, calagem, matéria orgânica, umidade do solo e água de irrigação (Kumar et al., 1993).

Bouma (1969), trabalhando com trevo subterrâneo, verificou que a deficiência de boro restringe o crescimento radicular, o que segundo Moraghan \& Mascagni (1991) pode intensificar o efeito do estresse hídrico.

Estudos conduzidos por Bartlett \& Picarelli (1973) mostram um comportamento semelhante do boro e do fósforo, com um decréscimo dos seus teores nas plantas, em função do aumento do $\mathrm{pH}$ no solo. Este comportamento suporta a hipótese de que o $B$ e o $P$ são fixados no solo por um mecanismo similar, dependente de $\mathrm{pH}$. Isto sugere que o íon borato e o fosfato são precipitados juntamente com o hidróxido de alumínio ou adsorvidos por ele, já que o hidróxido é prontamente precipitado pelas concentrações crescentes do íon hidroxila, em função da reação com o calcário aplicado no solo (Bartlett \& Picarelli, 1973 e Bloesch et al., 1987).

Para Evans \& Sparks (1983) o ácido bórico é a espécie predominante em níveis de $\mathrm{pH}$ abaixo de 7 , e sua adsorção é baixa devido a pequena afinidade deste com os minerais de argila. Para Goldberg \& Glaubig (1985) a adsorção de boratos em óxidos de $\mathrm{Fe}$ e $\mathrm{Al}$, em suas formas cristalina e/ou amorfa, é fortemente dependente do $\mathrm{pH}$, com taxa máxima entre 7 e 8, decrescendo em maiores valores de $\mathrm{pH}$.

Gupta (1993) cita que o pH do solo é um dos mais importantes fatores afetando a disponibilidade do boro no solo, sendo que este torna-se menos 
disponivel para as plantas com o aumento do $\mathrm{pH}$. Assim, a calagem em solos ácidos pode resultar em sintomas de deficiência do elemento. Gupta \& MacLeod ( 1977); Gupta \& MacLeod (1981) e Lehto \& Mälkönen (1994) sugerem que o efeito da deficiência de boro em solos após a calagem se deve ao $\mathrm{pH}$ do solo, ao invés dos níveis de cálcio adicionado ao solo.

A adsorção do boro no solo é altamente afetada pelo $\mathrm{pH}$, aumentando a medida que este aumenta no solo, alcançando o máximo na faixa alcalina e decrescendo a partir desse ponto (Keren et al., 1981).

\subsection{0 boro na planta}

Apesar do papel do boro no metabolismo das plantas estar ainda sujeito a consideráveis debates, os aspectos da nutrição com boro estão estreitamente ligados a estrutura primária da parede celular e função da membrana (Power \& Woods, 1997 e Blevins \& Lukaszewski, 1998).

Nos estudos conduzidos por Oertli \& Grgurevic (1975) foi concluído que a concentração interna de boro nas raízes e na solução externa é governada por equilíbrio de difusão do ácido bórico. Assim, o B difere fundamentalmente dos outros nutrientes os quais estão presente na forma ionizada e são transportados ativamente.

Reynolds et al. (1987) citam que em solos com pH ao redor de 6,8, a forma de nitrogênio aplicada no solo pode afetar consideravelmente a concentração de boro nas plantas, com a maior concentração de boro nos tecidos, em função da aplicação da fonte nitrogenada contendo a forma $\mathrm{NH}_{4}^{+}$. $\mathrm{O}$ aumento no teor de boro em plantas que foram adubadas com $\mathrm{N}-\mathrm{NH}^{+}{ }_{4}$ pode também em parte, ser devido a mudança na espécie de boro presente na rizosfera, em favor do ácido bórico, o qual é mais prontamente absorvido que o ânion borato.

Segundo Gil-Martinez (1995), o primeiro sintoma a aparecer na deficiência de boro é a morte do ápice dos brotos e das raízes, por seu 
requerimento na síntese de DNA, provocando o crescimento das brotações laterais, nas quais repete-se o mesmo fenômeno. Como resultado, as plantas afetadas apresentam uma formação típica de roseta, as folhas começam enrugar-se e deformar-se, os pecíolos e os talos se rompem; as flores geralmente nem chegam a se formar. Os órgãos de armazenamento caem afetados pelo apodrecimento interno e em alguns casos ocorre a formação de frutos e de sementes totalmente anormais. Este último fenômeno ocorre em função da maior necessidade de boro para as estruturas reprodutivas do que para as vegetativas.

O boro é um elemento de pouca mobilidade dentro da planta, e consequentemente os sintomas de sua deficiência se manifestam primeiramente nos tecidos jovens, recém formados (Calle-Manzano, 1985 e Adriano, 1986). Ao contrário, os tecidos adultos continuam em evolução durante algum tempo com normalidade, e posteriormente se origina-se uma ruptura dos vasos condutores. Como conseqüência, a planta cessa a formação de folhas ou estas formam-se deformadas, secando prematuramente (CalleManzano, 1985).

Baseado na similaridade estrutural entre as moléculas de $\mathrm{Al}(\mathrm{OH})_{3}$ e $\mathrm{B}(\mathrm{OH})_{3}$ e nos sintomas característicos de plantas estressadas pelo alumínio e em plantas com deficiência de boro, principalmente nos aspectos ligados à parede celular, função das membranas e crescimento radicular, foi proposto que o aluminio pode exercer um efeito tóxico pela indução da deficiência de boro às plantas (Blevins ${ }^{1}$, citado por Blevins \& Lukaszewski, 1998). Trabalho desenvolvido por LeNoble et al. (1996) mostrou que a incorporação de boro em subsolo ácido e com alto teor de alumínio promoveu melhor penetração radicular.

\footnotetext{
BLEVINS, D.G. Future developments in plant nutrition research. In: BOERSMA, L.L.; DE ELRICK, RB.; COREY, H.H. et al. (Ed). Future Developments in Soil Science Research.1987, p.445-448.
} 
O boro é complexado em compostos que contém grupos cis-hidroxilas (diol). O tipo formado é uma função da relação borato diol e $\mathrm{pH}$, com o tipo borato diol, sendo formado preferencialmente em solução com uma alta relação borato diol, enquanto o tipo borato (diol $)_{2}$ é formado numa relação mais baixa. A formação éster resulta numa intensificação da acidez e um complexo carregado negativamente (Shelp, 1993).

Kochian (1991) informa que o processo de absorção responsável pela entrada do elemento nas células das raízes das plantas não é totalmente conhecido. Porém, é consenso geral em favor de um processo passivo de difusão do $\mathrm{B}(\mathrm{OH})_{3}$ através da membrana plasmática, com a formação de ligações B-cis-diol com açúcares ou outros compostos polidróxidos dentro do citoplasma. Sendo assim, a força responsável pela entrada do boro para o simplasto é a difusão e a formação de ésteres estáveis com grupos cis-diol, o qual podem então permitir a difusão de ácido bórico livre para dentro da célula. Segundo Welch (1995), se esta visão estiver certa, o boro pode ser o único nutriente conhecido que é transportado através da membrana plasmática via um processo não mediado por uma proteína transportadora.

A absorção de boro pelas plantas pode ser explicada pelo transporte passivo de $\mathrm{B}(\mathrm{OH})_{3}$ e subsequente formação de complexos cis-diol, sem a necessidade de envolvimento de um transporte ativo do $B$. O transporte das raízes para a parte aérea está confinado ao xilema e relacionado com a taxa de transpiração. A regulação da absorção e translocação é ao contrário limitada, embora diferenças genotípicas na transferência raíz-parte aérea têm sido demonstradas. O boro é considerado como de translocação limitada; contudo, há evidências em diferentes espécies de plantas sugerindo que o suprimento de boro do floema é suficiente para sustentar o crescimento das brotações (Shelp, 1993). 


\subsection{Exigências nutricionais em boro na cultura do girassol}

A produção de girassol no Brasil e principalmente na região Centro Oeste é freqüentemente afetada em solos onde os teores de boro são baixos. Porém, estes baixos teores e $\mathrm{opH}$ do solo não interferem seriamente no desenvolvimento e produção das culturas que normalmente antecedem a cultura dos girassol como a soja ou o milho. O que se depreende imediatamente, é a sua grande sensibilidade aos baixos teores de boro e ao pH do solo.

O girassol é reconhecidamente uma espécie caracterizada pela pouca eficiência no aproveitamento do boro no solo (Blamey \& Chapman, 1982). Comparado com outras plantas, o girassol tem uma alta exigência em boro e, por esta razão, tem sido usada como uma planta teste para avaliar a disponibilidade de boro no solo (Schuster \& Stephenson, 1940). Vasudevan et al. (1997) destacam que a nutrição do girassol com boro, assume fundamental importância, uma vez que esta cultura é utilizada como uma planta indicadora da deficiência deste elemento no solo.

Em função do comportamento do girassol aos baixos teores de boro no solo, é interessante a busca por genótipos menos sensiveis à deficiência do nutriente e estabelecer programa de avaliação e seleção de genótipos quanto à eficiência na absorção e uso do boro (Furlani et al., 1990).

O girassol é sensivel a teores baixos de boro no solo, apresentando, com freqüência, nas principais regiões agrícolas do país, sintomas de deficiência desse elemento, principalmente nas fases de florescimento e maturação, com drástica redução da produção de grãos. O principal apoio, como ponto de partida para a definição das doses mais indicadas de fertilizantes, é a análise de solo e as produções dos cultivos anteriores, que são bons indicadores da fertilidade do solo (Castro et al., 1996).

$\mathrm{O}$ que se depreende é que o teor de umidade do solo parece ser o principal fator afetando a disponibilidade e absorção do boro por plantas de 
girassol. Dessa forma a época de plantio, o preparo adequado de solo ou o plantio direto em solos não compactados parece ser um bom manejo da cultura, possibilitando o desenvolvimento de seu sistema radicular em profundidade.

No campo, em condições adequadas de umidade do solo, os efeitos visíveis da deficiência de boro nos estádios vegetativos na cultura do girassol somente ocorrem se a mesma for extremamente severa.

Segundo Gupta (1993), a umidade do solo parece afetar a disponibilidade do boro mais do que qualquer outro nutriente. A reduzida solução do solo em conexão com o reduzido fluxo de massa, e a menor taxa de difusão, assim como o limitado fluxo transpiratório em plantas durante o período seco, pode ser o fator causal da deficiência de boro, apesar de um adequado suprimento de boro no solo.

Segundo Gutteres et al. (1988), como a disponibilidade excessiva de boro no solo pode ser tóxica para o girassol e às culturas seguintes, sua aplicação é aconselhável somente quando for constatada deficiência, cuja diagnose pode ser obtida através de uma análise de solo, recomendando-se a aplicação de $10 \mathrm{~kg} \mathrm{ha}^{-1}$ de bórax, quando o teor de boro extraído do solo por água quente for inferior a $0,30 \mathrm{mg} \mathrm{dm}^{-3}$.

Em condições de moderada deficiência de boro as plantas podem crescer normalmente e a produção foliar pode não ser severamente afetada, porém o rendimento de semente pode ser reduzido drasticamente. Numerosas observações têm levado à conclusão de que as necessidades de boro para a produção de sementes é muito maior que para a produção de folhagem (Gupta, 1993).

Segundo Sfredo et al. (1984), trabalhando em solos de Londrina-PR, o teor de boro nas folhas considerado suficiente para o girassol foi de $40 \mathrm{mg} \mathrm{kg}^{-1}$. Blamey (1977) estabeleceu os níveis de suficiência de boro nas folhas e 
aquênios de $47 \mathrm{mg} \mathrm{kg}^{-1}$ e $16 \mathrm{mg} \mathrm{kg}^{-1}$, respectivamente. Machado (1979) encontrou um teor adequado em torno de $50 \mathrm{mg} \mathrm{kg}^{-1}$ de boro nas folhas.

Birch et al. (1981) determinaram que o girassol é mais exigente em boro que o milho e o trigo, pois enquanto estes desenvolvem-se normalmente com teores de $5 \mathrm{mg} \mathrm{kg}^{-1}$ de boro nas folhas o girassol exige, segundo esses autores, $40 \mathrm{mg} \mathrm{kg}^{-1}$.

Gonzalez-Fernández et al. (1985) citam que é comum o aparecimento de deficiência de boro em lavouras de girassol na Espanha. Folhas com concentrações menores que $34 \mathrm{mg} \mathrm{kg}^{-1}$ do elemento apresentam sintomas de deficiência e queda da produção. Segundo os mesmos autores, não se espera o aparecimento de sintomas de deficiência em plantas, quando o teor de boro no solo, solúvel em água quente, for superior a $0,26 \mathrm{mg} \mathrm{dm}^{-3}$.

Kastori \& Petrovic (1989) encontraram que tanto a deficiência quanto a toxicidade de boro provocam um decréscimo do conteúdo total de nitrogênio nas raízes, na parte aérea e nas folhas de girassol. O conteúdo de boro em todas as partes das plantas analisadas aumentou com o aumento dos níveis de boro na solução nutritiva, em maior quantidade na parte aérea que nas raízes. Foi também observado que, tanto a deficiência quanto o excesso de boro provocaram diminuição na produção de matéria seca em todas as partes analisadas.

A deficiência ou o excesso de boro diminuem o acúmulo de $\mathrm{N}$ total e aumentam o conteúdo de nitrato em girassol, indicando uma obstrução na redução do nitrato a nitrito nas plantas de girassol, devido a diminuição da atividade da nitrato redutase, sendo este efeito mais acentuado nas raízes que na parte aérea (Kastori \& Petrovic, 1989).

Hill \& Morrill (1975), trabalhando em casa de vegetação com a cultura do amendoim, observaram uma interação entre os efeitos de $\mathrm{B}$ e $\mathrm{Ca}$ no crescimento e na qualidade da cultura. Tratamentos com altos niveis de Ca e sem aplicação de B proporcionaram acréscimo de produção, porém baixa 
qualidade de sementes. Essa baixa qualidade foi atribuída à redução da disponibilidade de $B$ em função do incremento do crescimento vegetativo. Em condições de campo não foi observada diferenças significativas de produção ou aumento de danos nas semente, em função da aplicação de doses de $\mathrm{B}$ e $\mathrm{Ca}$.

Segundo Quaggio et al. (1985), para se obter produção máxima, o girassol exige $\mathrm{pH}$ do solo ao redor de 6,5. Evans \& Sparks (1983) citam que a elevação do $\mathrm{pH}$ de 4,7 para 6,7 aumenta a disponibilidade de boro no solo.

Alleoni (1996), trabalhando com cinco solos do Estado de São Paulo, observou que a porcentagem de boro adsorvido pelos latossolos argilosos foi superior à dos podzólicos vermelho-amarelo que, por sua vez, foi superior à dos latossolos de textura média. A aplicação de carbonato de cálcio promoveu aumento na quantidade de boro adsorvido por todos os solos, sendo mais pronunciado o efeito nos latossolos de textura média.

Observa-se ao nivel de campo que, em lavouras de girassol implantadas após a calagem, são mais freqüentes os sintomas característicos de deficiência de boro. Essa constatação, nas condições de pH do solo em que normalmente são cultivadas as plantas, pode ser devido a maior disponibilidade de outros nutrientes, pela correção do solo.

Segundo Ellis et al. (1983), niveis tóxicos de boro para o crescimento das culturas ocorrem em muitos solos, particularmente em regiões áridas. Consequentemente, numerosos estudos têm sido conduzidos para determinar a facilidade com o qual o boro poderia ser lixiviado. Embora o boro ocorra como $\mathrm{H}_{3} \mathrm{BO}_{3}$ ou $\mathrm{B}(\mathrm{OH})_{4}^{-}$em valores de $\mathrm{pH}$ normalmente encontrado nos solos, ele é adsorvido mais fortemente no solo que muitos outros ânions tais como $\mathrm{Cl}^{-}$ou $\mathrm{NO}_{3}^{-}$(Ellis \& Kenezek, 1972). Além deste fator, o boro natural do solo é fixado numa forma que é vagarosamente liberado para a solução do solo e, desta forma é mais difícil do boro ser lavado do que outros sais solúveis.

Deficiências de boro na cultura do girassol, em condições de campo, normalmente produzem vários níveis de deformações nos capitulos, chegando 
mesmo em condições de estresse, provocar sua queda. É freqüente a redução da produtividade das lavouras por deficiência de boro, sem que sejam observados sintomas típicos nas folhas e capitulos.

As plantas no estádio reprodutivo são mais sensiveis a deficiência de boro que no estádio vegetativo, sendo o elemento requerido para a germinação do grão de pólen e também para o crescimento do tubo polínico. Quando ocorre a sua deficiência, o tubo polínico pára de crescer, não ocorrendo a fertilização, mas, como conseqüência, resultando na formação de sementes chochas em alta percentagem dos capitulos, com redução da produtividade (Calle-Manzano, 1985).

Segundo Blamey et al. (1979), embora o girassol seja particularmente sensivel à deficiência de boro, ela é relativamente fácil de ser corrigida. $\mathrm{Na}$ África do Sul, adubações com 1,0 kg/ha em solos arenosos e de $3,0 \mathrm{~kg} / \mathrm{ha}$ de B em solos argilosos, têm sido consideradas como adequadas para eliminar as deficiências de boro em cultivares sensiveis. Alternativamente às aplicações de boro via solo, o mesmo autor recomenda duas aplicações foliares com 0,4 e 0,6 $\mathrm{kg} / \mathrm{ha}$ de boro, aplicado no início do florescimento e durante florescimento pleno, respectivamente. Ungaro (1981) relata a grande importância do boro na cultura do girassol, recomendando a aplicação de $20 \mathrm{~kg}$ de bórax por hectare, em solos deficientes nesse elemento.

\subsection{Exigências hídricas da cultura do girassol}

O girassol é freqüentemente cultivado em condições não irrigadas. Apesar de ser considerado resistente à seca, em situações de limitada disponibilidade de água às plantas a produção de grãos é afetada drasticamente.

O déficit hídrico é o fator limitante primário para o desenvolvimento das culturas em solos agricultáveis (Boyer, 1982). Quedas nos rendimentos de soja, por exemplo, em função da falta de água são freqüentes, principalmente nos 
estados do centro-sul do país, causando enormes prejuizos econômicos e sociais (Bouças Farias, 1998).

Muitos pesquisadores têm apontado que plantas com sistema radicular profundo e vigoroso e com grande massa de raízes são mais tolerantes ao estresse hídrico, em função da absorção de água, nutrientes e ancoragem. Para o girassol esta característica também é válida, principalmente pelo fato que normalmente seu sistema radicular alcança a profundidade ao redor de dois metros (Jones, 1984 e Cox \& Jolliff, 1986).

A seca tem um profundo efeito no crescimento, rendimento e qualidade das plantas. O primeiro efeito do estresse hídrico é a perda de turgor que afeta as taxas de expansão celular e por último o tamanho celular. A perda de turgor é provavelmente o processo mais sensivel das plantas no periodo de seca. Como resultado há a redução do crescimento, da elongação do caule, da expansão foliar e da abertura dos estômatos (Hale \& Orcutt, 1987).

Kramer (1983) observa que o estresse hídrico afeta vários aspectos do crescimento das plantas, incluindo o anatômico, morfológico, fisiológico e bioquímico. O efeito geral mais óbvio referente ao estresse hídrico é a redução do tamanho das plantas, área foliar e o rendimento das culturas.

Uma observação interessante levantada por Turner \& Begg (1978) é a de que, sob condições experimentais o estresse hídrico é algumas vezes desenvolvido tão rapidamente, que os resultados não são comparáveis com aqueles obtidos em condições de campo, onde o estresse severo normalmente desenvolve-se mais gradualmente.

Hsiao (1973) estipulou como estresse suave aquele em que os decréscimos do potencial hídrico das folhas não ultrapassassem o valor de $-1,0$ $\mathrm{MPa}$ ou que o conteúdo relativo de água dos tecidos não decrescesse mais que $10 \%$. Estresse moderado ocorre quando decréscimos do potencial hídrico do tecido variam de $-1,1$ a $-1,5 \mathrm{MPa}$ e a redução no conteúdo relativo de água esteja entre 10 e $20 \%$. Plantas sob estresse severo apresentam uma variação 
no potencial hídrico das folhas inferior a $-1,6 \mathrm{MPa}$ e a redução no conteúdo relativo de água maior que $20 \%$. Tecidos onde a variação do conteúdo relativo de água for superior a $50 \%$ são ditos dessecados.

Em dias ensolarados sem forte advecção, folhas expostas de muitas culturas crescendo em solos bem irrigados exibem potencial hídrico ao meio dia variando entre -0,9 e -1,3 MPa, e com um conteúdo relativo de água entre 85 e $95 \%$. Entre a meia noite e o amanhecer, o potencial hídrico pode ser de $-0,1$ a $-0,2 \mathrm{MPa}$ e o conteúdo relativo de água atingir 100\%. Quando há um óbvio murchamento ou pronunciado fechamento de estômatos induzido pelo déficit de água nas folhas, o potencial hídrico é reduzido para -1,3 a -1,7 MPa. Este nivel corresponde aproximadamente ao ponto em que o turgor celular cai para perto de zero. A queda para $-3,0$ a $-3,5 \mathrm{MPa}$ se eqüivale a um conteúdo relativo de água ao redor de $45 \%$, resultando em morte das células (Hsiao \& Bradford, 1983).

O estresse hídrico moderado afeta indiretamente a translocação pela alteração da relação fonte e dreno. Devido a reduzida expansão celular, as folhas são menores e menos fotossintetisados estão disponiveis para translocação e enchimento dos frutos, sendo consequentemente o tamanho destes reduzido. Se o estresse hídrico ocorrer após a expansão foliar, o resultado da competição entre as folhas e os frutos é diminuída (Hale \& Orcutt, 1987).

A resposta à seca para muitas espécies é o acréscimo da proporção de fotoassimilados desviados para o crescimento radicular e, desta forma, aumenta a relação raiz/parte aérea e o volume de água do solo disponivel às plantas (O'Toole \& Bland, 1987); consequentemente aumentam-se as chances de sobrevivência nesse período.

A observação mais comum relativa às raízes sob condições de estresse é o acréscimo do peso de matéria seca da relação raiz/parte aérea. Esse acréscimo resulta do maior decréscimo relativo do crescimento da parte aérea 
do que do sistema radicular sob condições de estresse ( Kramer \& Boyer, 1995; Blum, 1997 e Belhassen, 1996). Contudo, Buwalda \& Lenz (1992), estudando o acúmulo e distribuição de biomassa e de nutrientes em macieiras, observaram que o estresse hídrico prolongado afetou a produção de frutos e da parte aérea em 21 e $26 \%$, respectivamente. Porém foi interessante notar que o peso seco do sistema radicular não foi afetado. Por outro lado, Malik et al. (1979), trabalhando com algodão, observaram um acréscimo em termos absolutos do peso das raízes sob condições de estresse.

Para Blum \& Arkin (1984), o acréscimo na relação peso do material seco de raiz/parte aérea freqüentemente implica no desenvolvimento de uma grande razão da densidade do sistema radicular e área foliar, o qual se traduz numa melhor capacidade para sustentação do estado hídrico das plantas sob uma dada demanda de evapotranspiração. Brouwer (1962) interpreta a mudança na relação entre a raiz e a parte aérea, como sendo um equilíbrio funcional, o qual favorece o desenvolvimento da parte da planta estreitamente relacionada com o fator limitante de crescimento, que é o sistema radicular durante o déficit hídrico.

Em solos com déficit hídrico, apesar do acréscimo na resistência do solo, o crescimento radicular é menos afetado que o crescimento da parte aérea, conduzindo ao típico acréscimo na relação do peso seca da raiz/parte aérea em resposta ao estresse hídrico (Marschner, 1995). Como exemplo, Sharp et al. (1988), trabalhando com plântulas de milho sem estresse hídrico, observaram que a relação do peso seco raiz/parte aérea mudou de 1,45 para 5,79 em plântulas sob condições de estresse.

Para Kramer \& Boyer (1995), a interdependência entre a raiz e a parte aérea sugere que pode existir uma ótima relação entre estes dois componentes. Contudo, a relação raiz/parte aérea varia amplamente entre as espécies com a idade e com as condições ambientais. Em regiões úmidas, as plantas não requerem aprofundar e espalhar vigorosamente seu sistema 
radicular para captação de água, porque a água do solo é suficiente e o total dela requerida para a transpiração pode, em teoria, ser fornecida por um volume relativamente pequeno de solo (Fitter \& Hay, 1987).

Durante o período em que ocorre a limitação de água há uma mudança no modelo de alocação dos produtos da fotossintese. Em muitas espécies, a maior parte do crescimento ocorre nos tecidos das raízes ao invés dos tecidos foliares. Assim, há um acréscimo na relação na relação raiz/parte aérea. Isto ocorre porque o ajuste na sua fisiologia relativa ao padrão de desenvolvimento afeta o modelo de alocação de fotossintetisados. O estresse hídrico que ocorre durante os estádios iniciais de crescimento causa uma grande mudança na relação peso do material seco de raiz/parte aérea. Em contraste, estresse hídrico durante a fase reprodutiva, tem um pequeno ou nenhum efeito nesta relação. Porém, o florescimento e a produção de sementes são reduzidas, ou a perda da frutificação aumenta (Nilsen \& Orcutt, 1996).

Um dos efeitos iniciais do estresse hídrico é a redução no desenvolvimento vegetativo. O crescimento da parte aérea, e em especial a expansão foliar é geralmente mais sensível que o crescimento radicular, e portanto primeiramente inibida (Hopkins, 1995 e Blum, 1997), enquanto a assimilação de carbono é, contudo, ainda mantida em níveis normais. O excesso de carbono produzido pode ser estocado, utilizado para o ajuste osmótico ou pode ser alocado para o crescimento radicular (Blum, 1997). Para Schildwacht (1988), um ajuste osmótico mais rápido do sistema radicular comparado com a parte aérea pode estar envolvido na mudança da relação peso do material seco de raiz/parte aérea.

$O$ aumento na relação peso do material seco de raiz/parte aérea tem sido devido à sensibilidade distinta da raiz e da parte aérea para o $A B A$ endógeno, ou para um maior ajuste osmótico nas raízes comparado com a parte aérea (Sharp \& Davies, 1989 e Taiz \& Zeiger, 1998). 
A absorção de nutrientes pelas raízes é seletivo e aproximadamente proporcional ao crescimento das plantas. O fluxo de água para as raízes é causado pela transpiração e assim está relacionado ao desenvolvimento das plantas. A concentração da solução do solo, contudo, é uma propriedade do solo e não é necessariamente ligado ao desenvolvimento das plantas. A taxa de entrada de nutrientes às raízes (influxo) é portanto normalmente diferente do fluxo de massa. Se o fluxo de massa de um nutriente ao redor das raízes é menor que o influxo das mesmas, o solo ao redor das raízes absorventes poderá ser depauperado. Este processo cria um gradiente de concentração no solo ao redor das raízes, criando um movimento de íons de uma região de maior potencial para uma de menor potencial o qual é denominada difusão (Jungk, 1996). Por outro lado se o fluxo de massa é significativamente maior que a taxa pelo qual o nutriente é absorvido, ocorre um acúmulo do nutriente ao redor das raízes.

Kramer (1983) cita que é improvável que um estresse hídrico moderado tenha algum efeito sério direto no movimento de íons de célula para célula. Contudo, devido ao movimento a longas distâncias no transporte de íons entre - sistema radicular e a parte aérea, que ocorre através da corrente transpiratória, pode ocorrer redução na taxa de transporte de íons, em plantas suficientemente estressadas para reduzir a transpiração. A absorção pode ser reduzida em função da menor mobilidade mineral, do menor desenvolvimento do sistema radicular e da suberização que diminui a permeabilidade radicular.

Viets ${ }^{2}$, citado por Kramer (1983) concluiu que a deficiência mineral raramente é a causa do reduzido crescimento vegetal em plantas sob condições de estresse hídrico. A única exceção pode ser o boro em solos deficientes no elemento. $O$ autor sugere que muitas plantas contém suficientes

\footnotetext{
${ }^{2}$ VIETS, F.G.Jr. Waterdeficits and nutrient availability. In: KOZLOWSKI, T.T. (Ed). Water deficts and plant growth. New York: Academic Press, 1972. v.4, p.217-239.
} 
reservas minerais para suportar um período de seca comum, mesmo porque, neste período o crescimento é reduzido ou mesmo paralisado.

A transpiração não é um processo constante, variando com a espécie vegetal, condições do solo, localização da água no solo, idade da planta e as condições climáticas. À noite, quando os estômatos estão fechados, o fluxo de massa torna-se restrito, causando uma flutuação diurna. Além disso, a concentração de nutrientes nas plantas varia grandemente com o estágio de desenvolvimento. Uma vez que as raizes são capazes de uma taxa de elongação muito maior do que os íons podem se difundir no solo, é provável que as raizes jovens tenham mais altas concentrações de nutrientes que as mais velhas (Flowers \& Yeo, 1992). Da mesma forma, plantas jovens possuem, usualmente, maior concentração de nutrientes pois consistem principalmente de tecidos jovens, os quais contém vários nutrientes em maiores concentrações que tecidos mais velhos; sendo assim, o fluxo de massa tem uma menor contribuição na demanda nutricional (Jungk, 1996).

A condição de umidade do solo é o principal fator ambiental afetando a disponibilidade do boro para as plantas. Na verdade, o estresse hídrico propicia a incidência e a severidade da deficiência de boro mais do que qualquer outro micronutriente (Moraghan \& Mascagni, 1991). Por exemplo, de acordo com Batey $^{3}$, citado por Moraghan \& Mascagni (1991), nabo (Brassica rapa) cultivado no País de Gales, normalmente torna-se deficiente em solos com teores menores que $0,3 \mathrm{mg} \mathrm{kg}^{-1}$ de boro. Contudo, foi observada deficiência do elemento em cultivos de campo, em verão seco, com níveis de boro no solo entre 0,5 e $0,6 \mathrm{mg} \mathrm{kg}^{-1}$.

Se o boro tem normalmente sua distribuição no perfil do solo em maiores

3 BATEY, T. Manganese and boron deficiency. In: WEBBER, J. (Ed). Trace elements in soils and crops. London: United Kingdom Ministry Agric., Fish. and Food Tech. BuIl, 1971. 21. 
concentrações nas camadas superficiais, então, a dinâmica de secagem do perfil, afetará primeiramente esta camada, restringindo a absorção de água e de boro desta região, e consequentemente reduzindo o suprimento de boro para os novos tecidos das plantas. Assim, a planta tem uma pequena oportunidade de se ajustar ao corte no suprimento externo através do boro previamente acumulado (Moraghan \& Mascagni, 1991).

As necessidades hídricas do girassol ainda não estão perfeitamente definidas, existindo informações que indicam desde menos de $200 \mathrm{~mm}$ até mais de $900 \mathrm{~mm}$ por ciclo. Entretanto, na maioria dos casos, 500 a $700 \mathrm{~mm}$ de água, bem distribuídos ao longo do ciclo, resultam em rendimentos próximos ao máximo potencial. O consumo de água pela cultura do girassol varia em função das condições climáticas, da duração do ciclo e do manejo do solo e da cultura. Entretanto, solos bem preparados e/ou com alta capacidade de armazenamento de água permitem à planta tolerar maiores períodos sem chuvas e/ou irrigação.

Segundo Gómez-Arnau (1988), o girassol tem um comportamento aparentemente contraditório quanto a baixa eficiência no uso da água. Esta baixa eficiência melhora muito em condições de estresse hídrico, já que sua eficiência relativa pode aumentar de 20 a $50 \%$, porque sua fotossintese se reduz comparativamente menos que as perdas de água por transpiração. Por isso e porque seu sistema radicular explora camadas muito profundas do solo, não exploradas por outros cultivos, considera-se uma planta que assegura algum rendimento, em condições onde outras espécies cultivadas não produziriam nada.

Estudos conduzidos por Oliveira (1997) demonstram o grande consumo de água pela cultura do girassol em condições de disponibilidade hídrica satisfatória. O autor, avaliando a transpiração pelo método de balanço de calor de plantas de girassol, milho, tomate e limão tahiti, com $0,3 \mathrm{~m}^{2}$ de área foliar, em casa de vegetação, num período de 10 dias de avaliação, observou que a 
transpiração do girassol foi destacadamente superior as demais espécies, alcançando os valores médios diários de 1449,24 g/dia, para o milho de 513,00 g/dia, para o tomate $285,44 \mathrm{~g} / \mathrm{dia}$ e para o limão tahiti de $661,36 \mathrm{~g} / \mathrm{dia}$.

A fase crítica quanto à necessidade de água no cultivo de girassol, se estende desde a fase em que o botão floral varia de três a cinco centímetros de diâmetro até 10 a 15 dias após o final da floração (Gómez-Arnau, 1988).

Segundo Marc \& Palmer (1976), o estresse hídrico reduz o número de folhas por planta quando o mesmo ocorre 20 dias após o plantio.

O girassol é considerado como uma planta resistente a seca e talvez por esse motivo, o rendimento de óleo é substancialmente reduzido se o estresse ocorrer durante o principal período de crescimento e no florescimento. $O$ principal sintoma da deficiência hídrica na fase vegetativa é a redução do número e tamanho das folhas.

Cox \& Jolliff (1986) trabalhando em três niveis de umidade concluíram que enquanto $o$ índice de área foliar foi o parâmetro de crescimento vegetativo mais sensível ao déficit de água no solo, o número de sementes por plantas foi o componente de rendimento mais afetado nas mesmas condições.

Boyer (1970), trabalhando com girassol, soja e milho e Rawson et al. (1980) com girassol, em casa de vegetação, verificaram que o girassol é sensivel ao estresse hídrico. Boyer (1970) observou em seu estudos que a expansão celular foi consideravelmente mais afetada que a fotossintese em baixo potencial hídrico das folhas. A completa supressão do crescimento foliar do girassol ocorreu com potencial hídrico da folha abaixo de -0,4 MPa. Desta forma, a grande inibição de crescimento em girassol em tais potenciais podem resultar em pequena expansão foliar durante o dia, mesmo em solos bem irrigados.

Temperaturas altas prejudicam o desenvolvimento da planta, principalmente em condições de baixa disponibilidade hídrica. A faixa de temperatura entre $10^{\circ} \mathrm{C}$ a $34^{\circ} \mathrm{C}$ é tolerada pelo girassol sem redução 
significativa da produção, indicando adaptação a regiões com dias quentes e noites frias. A temperatura ótima para o seu desenvolvimento situa-se na faixa entre $27^{\circ} \mathrm{C}$ a $28^{\circ} \mathrm{C}$ (Unger, 1990; Carter, 1978 e Weiss, 1983).

O girassol tem baixa eficiência no uso da água, cada litro de água consumido produz menos de dois gramas de matéria seca (Carter, 1978).

A necessidade de água para o girassol vai aumentando com o desenvolvimento da planta, partindo de valores ao redor de 0,5 a $1 \mathrm{~mm} / \mathrm{dia}$ durante a fase da semeadura à emergência para um máximo de 6 a $7 \mathrm{~mm} / \mathrm{dia}$ na floração e no enchimento de grãos, decrescendo após esse período. Uma adequada disponibilidade de água durante o período da germinação à emergência é necessária para a obtenção de uma boa uniformidade na população de plantas.

Segundo Vrânceanu (1977), as fases de desenvolvimento da planta mais sensiveis ao déficit hídrico são:

a) do início da formação do capítulo (final da fase de diferenciação do receptáculo e formação das emergências florais) e o começo da floração: afeta mais fortemente o rendimento de aquênio; e

b) época que segue imediatamente a floração, quando tem lugar a formação e o processo de enchimento de grãos: determina considerável perda na porcentagem e a produção de óleo.

Robelin (1967) destaca a sensibilidade máxima do girassol à seca 20 dias antes e 20 dias após a floração, época em que o déficit hídrico diminui consideravelmente a produção de aquênios e o conteúdo de óleo. A pior influência da seca sobre o conteúdo de óleo ocorre nos primeiros 10 dias após o secamento das flores liguladas, sendo portanto essa fase a mais crítica para a quantidade e qualidade da produção de girassol. 


\section{MATERIAL E MÉTODOS}

\subsection{Localização do experimento}

Este trabalho foi conduzido em casa-de-vegetação, localizada no Horto Experimental do Departamento de Ciências Biológicas da Escola Superior de Agricultura "Luiz de Queiroz", em Piracicaba-SP, cujas coordenadas geográficas são: Latitude $22^{\circ} 42^{\prime} 03^{\prime \prime} \mathrm{S}$, Longitude $47^{\circ} 38^{\prime} 01^{\prime \prime} \mathrm{W}$ e altitude média $576 \mathrm{~m}$.

\subsection{0 solo e suas características}

O solo utilizado foi um latossolo vermelho amarelo distrófico de textura média argilosa, fase cerradão, coletado na Fazenda Canchim, do Centro de Pesquisa Pecuária do Sudeste (EMBRAPA-CPPSE), cujas coordenadas geográficas são: Latitude $22^{\circ} 01^{\prime} \mathrm{S}$, Longitude $47^{\circ} 53^{\prime} \mathrm{W}$ e altitude média de $864 \mathrm{~m}$. Este solo foi escolhido por ser de uma região de cerrado e possuir baixos teores de boro. Após o destorroamento e homogeneização, o solo foi secado ao ar (TFSA) e passado em peneira de $2 \mathrm{~mm}$.

Amostras de solo foram analisadas no Laboratório de Análises de Solo do Setor de Nutrição Mineral de Plantas, do Departamento de Solos e Nutrição de Plantas da ESALQ-USP, seguindo metodologia descrita por Raij \& Quaggio (1983). A extração do $\mathrm{P}$ disponivel, Ca, Mg e $\mathrm{K}$ trocáveis foi feita através da metodologia da resina trocadora de íons; para o Al trocável empregou-se $\mathrm{KCl}$ $1 \mathrm{~mol} \mathrm{~L}^{-1}$ a $\mathrm{pH} 7,0$. Os micronutrientes $\mathrm{Cu}, \mathrm{Fe}, \mathrm{Mn}$ e $\mathrm{Zn}$ foram extraídos com DTPA-TEA, segundo metodologia descrita por Lindsay \& Norvell (1978), sendo a extração de boro realizada pelo método da água quente. 
O P foi determinado por espectrofotometria, o $\mathrm{K}$ por fotometria de chama, o $\mathrm{Ca}, \mathrm{Mg}, \mathrm{Cu}, \mathrm{Fe}, \mathrm{Mn}$ e Zn por espectrofometria de absorção atômica, a acidez potencial pelo método do SMP e o Al trocável, por titulometria com hidróxido de sódio. $\mathrm{O} \mathrm{pH}$ foi determinado diretamente com potenciômetro em suspensão de solo e cloreto de cálcio, relação 1:2,5. A determinação da matéria orgânica foi realizada com o dicromato de sódio em ácido sulfúrico e o boro foi determinado por colorimetria de azometina- $\mathrm{H}$.

A análise granulométrica foi realizada no Laboratório de Física do Solo do Departamento de Solos e Nutrição de Plantas da ESALQ-USP, sendo determinada por sedimentação, através do método da pipeta, utilizando-se o hidróxido de sódio $1,0 \mathrm{~mol} \mathrm{~L}^{-1}$ como dispersante, conforme metodologia preconizada por EMBRAPA (1979). Os resultados obtidos foram de $680 \mathrm{~g} \mathrm{~kg}^{-1}$ de areia, $60 \mathrm{~g} \mathrm{~kg}^{-1}$ de silte e $260 \mathrm{~g} \mathrm{~kg}^{-1}$ de argila, com classificação textural média argilosa.

Tabela 1. Resultados da análise química do latossolo vermelho amarelo distrófico.

\begin{tabular}{cccccccccc}
\hline $\begin{array}{c}\mathrm{pH} \\
\left(\mathrm{CaCl}_{2}\right)\end{array}$ & $\begin{array}{c}\mathrm{P} \\
\mathrm{mg} \mathrm{dm}^{-3}\end{array}$ & $\begin{array}{c}\mathrm{M} . \mathrm{O} \\
\mathrm{g} \mathrm{dm}^{-3}\end{array}$ & $\mathrm{~K}$ & $\mathrm{Ca}$ & $\mathrm{Mg}$ & $\mathrm{H}+\mathrm{Al}$ & $\mathrm{SB}$ & $\mathrm{T}$ & $\mathrm{V}$ \\
\hline 4,05 & 1,5 & 17,1 & 0,38 & 1,3 & 1,4 & 59,8 & 3,1 & 62,8 & 4,92 \\
\hline $\mathrm{B}$ & $\mathrm{Cu}$ & & $\mathrm{Fe}$ & $\mathrm{Mn}$ & $\mathrm{Zn}$ \\
\hline 0,27 & 0,8 & & 42,1 & & & \\
\hline
\end{tabular}

\subsection{Genótipo de girassol}

Foi empregado o híbrido Morgan 738, de ciclo semi-tardio, material genético de elevado potencial produtivo, que vem se destacando na rede oficial 
de avaliação de genótipos (Balla et al., 1996), lançado no mercado na safra 1998/1999.

\subsection{Recipientes}

As plantas foram cultivadas em vasos de plástico, com volume de 10 litros, vazados no fundo e protegidos por tela de náilon para evitar perda de solo, onde foram adicionados $10 \mathrm{~kg}$ de solo para a condução do experimento.

\subsection{Calagem e adubação}

Com base na análise química do solo, realizou-se a correção da acidez, com o objetivo de elevar a saturação por bases a $60 \%$.

$\mathrm{Na}$ correção da acidez utilizou-se $\mathrm{CaCO}_{3}$ e $\mathrm{MgCO}_{3}$ na forma de sal puro para análise, em proporções adequadas objetivando uma relação de 3:1 de $\mathrm{Ca}$ e Mg. Para tanto foi adicionado em cada vaso $10,995 \mathrm{~g}$ de $\mathrm{CaCO}_{3}$ e $3,079 \mathrm{~g}$ de $\mathrm{MgCO}_{3}$. Após a adição do corretivo, foi aplicado em cada vaso $200 \mathrm{mg} \mathrm{kg}^{-1} \mathrm{de}$ $\mathrm{P}$ na forma de sal puro para análise $\left(\mathrm{Ca}\left(\mathrm{H}_{2} \mathrm{PO}_{4}\right)_{2} \cdot \mathrm{H}_{2} \mathrm{O}\right)$. Posteriormente, o solo foi incubado, mantendo-o permanentemente úmido $(0,12 \mathrm{~g}$ de água/g de solo) por um período de 30 dias. Ao final deste período, realizou-se análise química (Tabela 2).

Tabela 2. Resultados da análise química do latossolo vermelho amarelo distrófico após o período de incubação com $\mathrm{CaCO}_{3}$ e $\mathrm{MgCO}_{3}$.

\begin{tabular}{|c|c|c|c|c|c|c|c|c|c|}
\hline $\begin{array}{c}\mathrm{pH} \\
\left(\mathrm{CaCl}_{2)}\right.\end{array}$ & 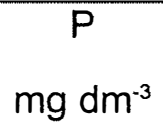 & $\begin{array}{l}\text { M.O. } \\
\mathrm{g} \mathrm{dm}^{-3}\end{array}$ & \multicolumn{6}{|c|}{$-\mathrm{mmol}_{\mathrm{c}} \mathrm{dm}^{-3}$} & $\begin{array}{l}\mathrm{V} \\
\%\end{array}$ \\
\hline 5,6 & 63 & 25 & 0,4 & 30 & 6 & 25 & 36,4 & 61,4 & 59 \\
\hline \multicolumn{2}{|c|}{$B$} & $\mathrm{Cu}$ & \multicolumn{3}{|c|}{$\mathrm{Fe}$} & $\bar{M}$ & \multicolumn{3}{|c|}{$\mathrm{Zn}$} \\
\hline \multicolumn{2}{|c|}{0,29} & 0,8 & \multicolumn{3}{|c|}{27,6} & 4 & & \multicolumn{2}{|c|}{0,2} \\
\hline
\end{tabular}


Em seguida, o solo recebeu o restante dos macro e micronutrientes. Os teores de boro foram adicionados de acordo com as respectivas doses para cada tratamento. Após a adição dos nutrientes, o solo foi incubado por um período de 20 dias, mantendo-o permanentemente úmido. Na Tabela 3 estão descritos as doses e produtos dos nutrientes adicionados em cada vaso.

Tabela 3. Doses de nutrientes e produtos químicos fornecidos por vaso.

\begin{tabular}{|c|c|c|c|c|}
\hline \multirow{3}{*}{ Elemento } & \multicolumn{3}{|c|}{$\left(\mathrm{mg} \mathrm{kg}^{-1}\right)$} & \multirow{3}{*}{ Produto } \\
\hline & \multirow[t]{2}{*}{ Semeadura } & \multicolumn{2}{|c|}{ Cobertura } & \\
\hline & & $1^{\mathrm{a}}$ & $2^{a}$ & \\
\hline$N$ & 60 & 70 & 70 & $\mathrm{NH}_{4} \mathrm{NO}_{3}$ \\
\hline$P$ & 200 & & - & $\mathrm{Ca}\left(\mathrm{H}_{2} \mathrm{PO}_{4}\right)_{2} \cdot \mathrm{H}_{2} \mathrm{O}$ \\
\hline K & 60 & 70 & 70 & $\mathrm{~K}_{2} \mathrm{SO}_{4}$ \\
\hline $\mathrm{Ca}{ }^{(1)}$ & 129 & - & - & - \\
\hline $\mathrm{Mg}$ & 27 & - & - & $\mathrm{MgSO}_{4} \cdot 7 \mathrm{H}_{2} \mathrm{O}$ \\
\hline$S^{(1)}$ & 44 & - & - & - \\
\hline $\mathrm{Zn}$ & 5,0 & - & - & $\mathrm{ZnSO}_{4} \cdot \mathrm{H}_{2} \mathrm{O}$ \\
\hline $\mathrm{Fe}$ & 5,0 & - & - & Fe-EDTA \\
\hline $\mathrm{Mn}$ & 10 & - & - & $\mathrm{MnSO}_{4} \cdot \mathrm{H}_{2} \mathrm{O}$ \\
\hline $\mathrm{Cu}$ & 1,5 & - & - & $\mathrm{CuSO}_{4} \cdot 5 \mathrm{H}_{2} \mathrm{O}$ \\
\hline Mo & 0,5 & - & - & $\mathrm{Na}_{2} \mathrm{Mo}_{4} \cdot 2 \mathrm{H}_{2} \mathrm{O}$ \\
\hline
\end{tabular}

(1) Os teores de $\mathrm{Ca}$ e $\mathrm{S}$ foram fornecidos através das fontes de $\mathrm{P}, \mathrm{K}, \mathrm{Mg}, \mathrm{Cu}, \mathrm{Fe}, \mathrm{Mn}$ e $\mathrm{Zn}$.

Após esta incubação foram coletadas amostras de solo de cada tratamento para análise química. A semeadura foi efetuada no solo com as características químicas constantes na Tabela 4.

Aos 65 dias após a emergência das plantas (início de florescimento) foram coletadas amostras de solo de uma repetição (16 vasos), cujas plantas foram coletadas para determinação da matéria seca do girassol e controle de umidade (Tabela 5). 
Tabela 4. Resultados da análise química do latossolo vermelho amarelo distrófico após a aplicação de macro e micronutrientes.

\begin{tabular}{llllllllllll}
\hline Dose B & pH & P & M.O. & K & Ca & Mg & H+Al & SB & T & V
\end{tabular}

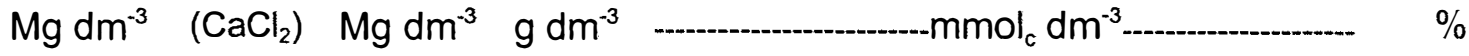

\begin{tabular}{lllllllllll}
\hline 0,0 & 5,6 & 53 & 22 & 1,2 & 26 & 6 & 25 & 33,2 & 58,2 & 57 \\
0,25 & 5,6 & 54 & 21 & 1,1 & 25 & 6 & 22 & 32,1 & 54,1 & 59 \\
0,50 & 5,5 & 66 & 19 & 1,0 & 29 & 4 & 25 & 34,0 & 59,0 & 58 \\
2,00 & 5,5 & 54 & 17 & 1,3 & 27 & 6 & 25 & 34,3 & 59,3 & 58 \\
\hline Dose B & B & & Cu & Fe & & Mn & Zn \\
\hline 0,0 & & 0,22 & & 1,6 & 32,2 & 10,4 & 5,0 \\
0,25 & 0,29 & 1,8 & 31,4 & 9,4 & 4,8 \\
0,50 & 0,60 & 2,2 & 37,8 & 11,8 & 5,4 \\
2,00 & 1,27 & 1,8 & 32,0 & 10,0 & 4,6 \\
\hline
\end{tabular}

Tabela 5. Resultados da análise química do latossolo vermelho amarelo distrófico coletado no início de florescimento.

\begin{tabular}{lllllllllll}
\hline Dose B & pH & P & M.O. & K & Ca & Mg & H+Al & SB & T & V
\end{tabular}
$\begin{array}{llll}\mathrm{Mg} \mathrm{dm}^{-3} & \left(\mathrm{CaCl}_{2}\right) & \mathrm{Mg} \mathrm{dm}^{-3} & \mathrm{~g} \mathrm{dm}^{-3}\end{array}$ $-\mathrm{mmol}_{\mathrm{c}} \mathrm{dm}^{-3}$ $\%$

\begin{tabular}{|c|c|c|c|c|c|c|c|c|c|c|}
\hline 0,0 & 4,9 & 64 & 18 & 7,6 & 26 & 8 & 28 & 41,6 & 69,6 & 60 \\
\hline 0,25 & 4,9 & 72 & 17 & 8,5 & 26 & 8 & 28 & 42,5 & 70,5 & 60 \\
\hline 0,50 & 4,9 & 78 & 17 & 9,2 & 31 & 10 & 28 & 50,2 & 78,2 & 64 \\
\hline 2,00 & 4,9 & 70 & 18 & 8,0 & 30 & 9 & 29 & 47,0 & 76,0 & 62 \\
\hline \multicolumn{2}{|l|}{ Dose B } & $B$ & \multicolumn{2}{|c|}{$\mathrm{Cu}$} & \multicolumn{2}{|c|}{$\mathrm{Fe}$} & \multicolumn{2}{|c|}{$\mathrm{Mn}$} & \multicolumn{2}{|c|}{$\mathrm{Zn}$} \\
\hline \multirow{2}{*}{\multicolumn{2}{|c|}{0,00}} & & & & & & & & & \\
\hline & & 0,27 & \multicolumn{2}{|c|}{1,3} & \multicolumn{2}{|c|}{26,4} & \multicolumn{2}{|c|}{14,2} & \multicolumn{2}{|c|}{3,2} \\
\hline \multicolumn{2}{|l|}{0,25} & 0,34 & \multicolumn{2}{|c|}{1,3} & \multicolumn{2}{|c|}{26,4} & \multicolumn{2}{|c|}{13,5} & \multicolumn{2}{|c|}{3,2} \\
\hline \multicolumn{2}{|l|}{0,50} & 0,43 & \multicolumn{2}{|c|}{1,3} & \multicolumn{2}{|c|}{25,9} & \multicolumn{2}{|c|}{14,4} & \multicolumn{2}{|c|}{3,2} \\
\hline \multicolumn{2}{|l|}{2,00} & 1,53 & \multicolumn{2}{|c|}{1,3} & \multicolumn{2}{|c|}{26,5} & \multicolumn{2}{|c|}{14,6} & \multicolumn{2}{|c|}{3,3} \\
\hline
\end{tabular}




\subsection{Delineamento experimental e análise estatística}

O delineamento experimental utilizado foi o de blocos completos ao acaso, em esquema fatorial $4 \times 4$ (quatro doses de boro e quatro épocas de controle de umidade no solo) com quatro repetições, totalizando 64 unidades experimentais com uma planta por vaso.

Os resultados foram submetidos à análise de variância, completada pelo teste F. Para os fatores qualitativos a comparação entre médias foi feita pelo teste de Tukey, ao nivel de $5 \%$ de probabilidade. Para o quantitativo, foi realizada a análise de regressão polinomial. Ajustou-se também a equações de Mitscherlich:

$$
Y=A\left[1-10^{-c(x+b)}\right]
$$

Nesta equação, o termo A representa a produção máxima teórica possivel, c é o coeficiente de eficácia do nutriente em estudo e b seria o teor do nutriente contido no solo, em forma assimilável pelas plantas (Pimentel-Gomes, 1953).

\subsection{Tratamentos}

As doses de boro fornecidas como ácido bórico $\left(\mathrm{H}_{3} \mathrm{BO}_{3}\right)$ e as fases de aplicação do estresse hídrico foram:

- 0,00 ( teor natural de boro no solo);

- $0,25\left(0,25 \mathrm{mg} \mathrm{kg}^{-1}\right.$ de B);

- $0,50\left(0,50 \mathrm{mg} \mathrm{kg}^{-1}\right.$ de B);

- 2,00 (2,00 $\mathrm{mg} \mathrm{kg}^{-1}$ de B).

Fases de aplicação do estresse hídrico:

- Sem estresse hídrico (SEM);

- Com estresse hídrico (COM);

- Estresse hídrico a partir do início do florescimento (IFL); 
- Estresse hídrico a partir do início do enchimento de aquênios (IEA).

No tratamento SEM, as plantas foram cultivadas sob condições ótimas de água para o seu desenvolvimento durante todo o ciclo da cultura, não sendo imposta nenhuma restrição hídrica.

No tratamento COM, as plantas foram cultivadas durante todo o seu ciclo de desenvolvimento em condições de estresse hídrico.

Nos tratamentos IFL e IEA, as plantas foram cultivadas sob condições ótimas de água até o início do florescimento e início de enchimento de aquênios, respectivamente. A partir destes estádios, foram impostos estresses hídricos às plantas. A imposição do estresse hídrico, foi estabelecida pela redução dos níveis de água destes tratamentos de $1,2 \mathrm{~kg}$ de água por vaso para o nível do tratamento com estresse $0,9 \mathrm{~kg}$ de água por vaso, a partir dos 65 (IFL) e 77 dias (IEA).

\subsection{Níveis de água no solo}

A determinação da curva de retenção de água, de amostras deformadas de solo (Tabela 6), foi realizada no Laboratório de Física do Solo do Centro de Energia Nuclear na Agricultura (CENA-USP).

Tabela 6. Curva de retenção de água no solo

\begin{tabular}{ccc}
\hline Potencial mátrico & \multicolumn{2}{c}{ Conteúdo de água no solo (g de água/g de solo) } \\
\cline { 2 - 3 } (cm de água) & Mensurado & Estimado \\
\hline 0 & 0,505 & 0,505 \\
50 & 0,177 & 0,174 \\
100 & 0,125 & 0,134 \\
330 & 0,111 & 0,105 \\
1000 & 0,106 & 0,097 \\
5000 & 0,094 & 0,094 \\
15000 & 0,093 & 0,093 \\
\hline
\end{tabular}


Os níveis de água no solo foram escolhidos com base na curva de retenção de água e em testes rápidos de retenção de água, realizados em casa de vegetação, utilizando os mesmos vasos com solo empregados no experimento. Sendo assim, com base na curva de retenção de água no solo que apresentou baixa capacidade de retenção sob baixa tensão, e nos testes em casa de vegetação, foram adotadas como quantidades ideais de água 0,12 e 0,09 g de água/g de solo, para os tratamentos sem e com estresse hídrico, respectivamente.

\subsection{Aplicação dos nutrientes}

Os nutrientes foram fornecidos na forma de solução, homogeneizada ao volume total do solo e, posteriormente, nas doses de boro (tratamento), seguiuse o mesmo procedimento. As coberturas com $\mathrm{N}$ e $\mathrm{K}$ foram aplicadas em forma de solução na superfície do solo, aos 15 e 45 dias após a emergência.

\subsection{Semeadura}

A semeadura foi realizada em 22 de março de 1998, empregando-se cinco sementes do híbrido Morgan 738 por vaso. A emergência ocorreu quatro dias após. Em 30 de março foi efetuado o primeiro desbaste, deixando-se duas plantas por vaso; três dias após foi efetuado novo desbaste (nove dias após a emergência), deixando-se somente uma planta por vaso.

\subsection{Monitoramento e controle da umidade do solo}

Diariamente foi efetuado o monitoramento da umidade do solo através de pesagens dos vasos, mantendo-se a quantidade de água em função de cada tratamento, pré-estabelecido . Nas pesagens foi utilizada a balança digital Marte LC 50, com carga mínima e máxima de $250 \mathrm{~g}$ e $50 \mathrm{~kg}$, respectivamente, e precisão de $10 \mathrm{~g}$, instalada dentro da casa de vegetação. 
Os vasos sob estresse (COM) foram pesados diariamente as 14:00 e 20:00 horas, adicionando-se a quantidade de água perdida no período anterior. Os vasos sem estresse (SEM, IFL e IEA) eram pesados somente uma vez por dia às 20:00 horas. Inicialmente todos os tratamentos foram mantidos com 1,2 $\mathrm{kg}$ de água, objetivando uma germinação e emergência uniforme das plantas. $A$ partir da emergência, somente os tratamentos sem estresse (SEM, IFL e IEA) foram mantidos com $1,2 \mathrm{~kg}$ de água por vaso, permanecendo com esta quantidade de água, até os 35 dias após a emergência das plantas. As plantas do tratamento COM foram mantidas durante o mesmo período com 0,9 $\mathrm{kg}$ de água.

Foram conduzidas ao longo do experimento nove repetições (144 vasos): quatro repetições para os dados de produção e nutrientes e cinco repetições serviram basicamente para a avaliação do desenvolvimento, coleta e pesagem das plantas (parte aérea e raiz). As coletas foram realizadas aos 35 , 54, 65 (início do florescimento), 77 (início do enchimento de aquênios) e 89 dias após a emergência das plantas. Com base nos pesos das plantas, foi possível corrigir as quantidades de água e dessa forma, manter os níveis de estresse, conforme apresentado na Tabela 7. A quantidade de água adicionada nos tratamentos foi ajustada através das curvas de produção de matéria seca em função das doses de boro para cada fase de aplicação de estresse, aos 35 , $54,65,77$ e 89 dias após a emergência das plantas (Apêndice 1).

$\mathrm{Na}$ Tabela 8 são apresentados os pesos totais das plantas de cada tratamento, tomados como base para o ajuste da quantidade de água a ser aplicada nos respectivos tratamentos. As diferenças entre os pesos das plantas por tratamento e as quantidades de águas acrescidas em cada vaso (Tabelas 7 e 8), são devido ao ajuste nos pesos das plantas em função dos desvios de desenvolvimento destas.

$\mathrm{Na}$ Tabela 8 verifica-se que até os 65 dias os tratamentos SEM, IEA e IFL foram tomados em conjunto, devido estes não estarem sob condição de 
estresse. A partir dos 65 dias, com a aplicação do estresse hídrico no tratamento IFL, este foi pesado em separado dos demais. O mesmo procedimento foi adotado para o tratamento IEA aos 77 dias.

Tabela 7. Quantidade de água acrescida em cada vaso a partir dos períodos de coleta das plantas, em função das doses de boro.

\begin{tabular}{|c|c|c|c|c|c|}
\hline Período & Dose B & SEM/IFL/IEA & COM & $\mathrm{IFL}$ & IEA \\
\hline (dias) & $\left(\mathrm{mg} \mathrm{kg}^{-1}\right)$ & & & רו & -- \\
\hline \multirow{4}{*}{35} & 0,00 & 100 & 30 & - & - \\
\hline & 0,25 & 110 & 40 & - & - \\
\hline & 0,50 & 120 & 50 & - & - \\
\hline & 2,00 & 120 & 60 & - & - \\
\hline \multirow{4}{*}{54} & 0,00 & 210 & 80 & - & - \\
\hline & 0,25 & 230 & 100 & - & - \\
\hline & 0,50 & 250 & 110 & - & - \\
\hline & 2,00 & 240 & 110 & - & - \\
\hline \multirow{5}{*}{$65^{\star}$} & & SEM/IEA & COM & $\mathrm{IFL}$ & IEA \\
\hline & 0,00 & 220 & 100 & 220 & - \\
\hline & 0,25 & 260 & 120 & 260 & - \\
\hline & 0,50 & 290 & 130 & 290 & - \\
\hline & 2,00 & 300 & 140 & 300 & - \\
\hline \multirow{5}{*}{$77^{\star}$} & & SEM & COM & IFL & IEA \\
\hline & 0,00 & 290 & 110 & 220 & 290 \\
\hline & 0,25 & 330 & 130 & 260 & 330 \\
\hline & 0,50 & 360 & 150 & 290 & 360 \\
\hline & 2,00 & 370 & 150 & 290 & 370 \\
\hline \multirow{4}{*}{89} & 0,00 & 300 & 120 & 260 & 270 \\
\hline & 0,25 & 350 & 140 & 290 & 330 \\
\hline & 0,50 & 390 & 160 & 320 & 370 \\
\hline & 2,00 & 380 & 170 & 290 & 360 \\
\hline
\end{tabular}

${ }^{*}$ Aos 65 dias as plantas dos tratamentos SEM/IEA e IFL receberam as mesmas quantidades de água pois até esta data não estavam sob estresse e portanto tinham peso semelhante. Assim, deveriam receber as mesmas quantidade de água.

* Aos 77 as mesmas observação devem ser feitas para as plantas dos tratamentos SEM e IEA. 
Tabela 8. Peso da matéria fresca de plantas de girassol, nos períodos de coleta das plantas, em função das doses de boro.

\begin{tabular}{|c|c|c|c|c|c|}
\hline \multirow{2}{*}{$\begin{array}{c}\text { Período } \\
\text { (dias) }\end{array}$} & \multirow{2}{*}{$\begin{array}{c}\text { Dose B } \\
\left(\mathrm{mg} \mathrm{kg}^{-1}\right)\end{array}$} & SEM/IEA/IFL & COM & $\overline{\mathrm{IFL}}$ & $\overline{\mathrm{IEA}}$ \\
\hline & & \multicolumn{4}{|c|}{ 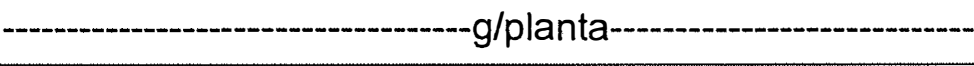 } \\
\hline \multirow{4}{*}{35 dias* } & 0,00 & 94,5 & 30,3 & - & - \\
\hline & 0,25 & 109,1 & 45,1 & - & - \\
\hline & 0,50 & 114,7 & 49,4 & - & - \\
\hline & 2,00 & 117,3 & 56,2 & - & - \\
\hline \multirow{4}{*}{54 dias } & 0,00 & 209,1 & 87 & - & - \\
\hline & 0,25 & 229,1 & 95,8 & - & - \\
\hline & 0,50 & 245,2 & 115,2 & - & - \\
\hline & 2,00 & 236,1 & 110,9 & - & - \\
\hline \multirow{4}{*}{65 dias } & 0,00 & 221,71 & 107,4 & - & - \\
\hline & 0,25 & 256,99 & 105,52 & - & - \\
\hline & 0,50 & 288,11 & 136,7 & - & - \\
\hline & 2,00 & 296,94 & 140,4 & - & - \\
\hline & & SEM/IEA & $\overline{C O M}$ & $\overline{\mathrm{IFL}}$ & $\overline{\mathrm{IEA}}$ \\
\hline \multirow{4}{*}{77 dias } & 0,00 & 289,19 & $\overline{112,6}$ & 227,0 & - \\
\hline & 0,25 & 340,20 & 133,9 & 242,4 & - \\
\hline & 0,50 & 360,35 & 148,2 & 289,7 & - \\
\hline & 2,00 & 366,92 & 150,0 & 284,9 & - \\
\hline & & SEM & $\overline{C O M}$ & $\overline{I F L}$ & IEA \\
\hline \multirow{4}{*}{89 dias } & 0,00 & 301,2 & 120,6 & 263,1 & 264,2 \\
\hline & 0,25 & 356,8 & 148,3 & 289,3 & 339,8 \\
\hline & 0,50 & 389,7 & 154,8 & 323,8 & 363,8 \\
\hline & 2,00 & 384,9 & 165,9 & 287,5 & 361,3 \\
\hline
\end{tabular}

35 a 65 dias: média de três plantas por dose de $B$ nos tratamentos SEM/IFL/IEA e de uma planta por dose de $\mathrm{B}$ para o tratamento COM;

* 77 dias: média de duas plantas por dose de B nos tratamentos SEM/IEA e de uma planta por dose para os tratamento COM e IFL;

* 89 dias: peso de uma planta por dose de B para todos os tratamentos.

\subsection{Avaliações}

\subsubsection{Determinação da área foliar}

A área das folhas fisiologicamente ativas foi determinada pelo integrador de área modelo LI-3100, produzido por Li-Cor. Lincoln, Nebraska, USA. Foram 
determinadas aos 35, 54, 65 (início do florescimento) e 77 dias (início do enchimento de aquênios). Nas plantas colhidas aos 89 dias não foi determinada a área foliar devido ao grande número de folhas secas em relação às fisiologicamente ativas.

\subsubsection{Determinação matéria seca de plantas e rendimento de aquênios}

Após a passagem das folhas no integrador de área foliar, todo 0 material, acrescidas das folhas secas e demais partes da planta, caule e raiz, foram secas em estufa a $65^{\circ} \mathrm{C}$, até peso constante. A produção de matéria seca da parte aérea foi obtida pela soma dos pesos da haste, folhas e capitulo, sendo a da matéria seca total obtida pela soma da parte aérea, raiz e aquênios. Para a determinação do peso dos aquênios o teor de umidade foi corrigido para $11 \%$. Utilizou-se balança digital modelo BG 1000, produzido por Ind. Comp. Eletro-Eletrônica GEHAKA Ltda - SP.

\subsubsection{Determinação da altura das plantas}

A altura das plantas foi obtida no estádio de plena floração $\left(R_{55}\right)$, medida com régua, do nível do solo até o ponto inserção do capítulo (Castiglioni et al., 1994).

\subsubsection{Potencial hídrico das folhas}

A intensidade do estresse era verificada através da medição do potencial hídrico de plântulas e folhas, utilizando-se como padrão a folha mais jovem e totalmente expandida de cada tratamento. As medidas foram tomadas em seis épocas distintas: no último desbaste, realizado aos nove dias e ao longo do experimento, aos $35,54,65,77$ e 89 dias, entre 5:00 e 6:20 horas.

As medidas tinham como objetivo verificar se as quantidades distintas de água para cada tratamento, estavam realmente refletindo no potencial hídrico das plantas e por conseguinte, se de fato aplicado estresse hídrico. Através 
destas medidas foi possível confirmar se os diferenciais de umidade de cada tratamento estavam realmente impondo um estresse hídrico às plantas.

Para a determinação do potencial hídrico (Tabela 9) foi utilizado a Câmara de pressão de Scholander, modelo PMS 1003, produzido por Soilmoisture Equipment Corp. Santa Barbara, CA, USA (Figura 1).

Tabela 9. Potencial hídrico medido em plântulas ${ }^{1}$ e folhas ${ }^{2}$ de girassol, nos períodos de coleta das plantas.

\begin{tabular}{|c|c|c|c|c|c|c|c|c|}
\hline \multirow{2}{*}{$\begin{array}{c}\text { Período } \\
\text { (dias) }\end{array}$} & \multicolumn{2}{|c|}{ SEM/IFL/IEA } & \multicolumn{2}{|c|}{ COM } & \multicolumn{2}{|c|}{$\overline{I F L}$} & \multicolumn{2}{|c|}{ IEA } \\
\hline & máximo & mínimo & máximc & mínimo & Máximo & mínimo & máximo & Mínimo \\
\hline & \multicolumn{8}{|c|}{ 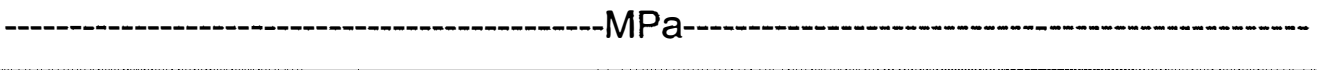 } \\
\hline 9 & $-0,56$ & $-0,54$ & $-1,33$ & $-1,27$ & - & - & - & - \\
\hline 35 & $-0,49$ & $-0,46$ & $-0,84$ & $-0,78$ & - & - & - & - \\
\hline 54 & $-0,42$ & $-0,24$ & $-0,80$ & $-0,78$ & - & - & - & - \\
\hline \multirow[t]{2}{*}{65} & $-0,49$ & $-0,29$ & $-0,90$ & $-0,84$ & - & - & - & - \\
\hline & \multicolumn{2}{|c|}{ SEM/IEA } & \multicolumn{2}{|c|}{ COM } & \multicolumn{2}{|c|}{$\mathrm{IFL}$} & \multicolumn{2}{|c|}{ IEA } \\
\hline \multirow[t]{2}{*}{77} & $-0,46$ & $-0,21$ & $-0,69$ & $-0,62$ & $-0,76$ & $-0,58$ & - & - \\
\hline & \multicolumn{2}{|c|}{ SEM } & \multicolumn{2}{|c|}{ COM } & \multicolumn{2}{|c|}{ IFL } & \multicolumn{2}{|c|}{ IEA } \\
\hline 89 & $-0,48$ & $-0,24$ & $-0,72$ & $-0,56$ & $-0,60$ & $-0,48$ & $-0,55$ & $-0,44$ \\
\hline
\end{tabular}

${ }^{1}$ Aos nove dias o potencial hídrico foi medido nas plântulas.

${ }^{2}$ Nos demais período o potencial hídrico foi medido em folhas.

\subsubsection{Monitoramento da radiação fotossinteticamente ativa}

A radiação fotossinteticamente ativa na casa-de-vegetação não foi limitante ao desenvolvimento das plantas. Valores médios de $1100 \mu \mathrm{mol} \mathrm{s} \mathrm{s}^{-1} \mathrm{~m}^{-2}$, ao redor da 12:00 horas, foram registrados utilizando-se um medidor portátil de PAR modelo Li-250 (Li-cor, Inc., Lincoln, NE, USA).

\subsubsection{Análise química no material vegetal}

A coleta das folhas foi realizada no início do florescimento, estádio $R_{4}$, conforme metodologia de identificação das fases de desenvolvimento da 
cultura do girassol descrita Castiglioni et al. (1994). Nas análises dos teores dos nutrientes nas folhas, os tratamentos SEM, IFL e IEA, foram tomados em conjunto, e denominados como tratamento SEM, pois até o início do florescimento não sofreram estresse hídrico. As folhas coletadas correspondem a mais jovem fisiologicamente ativa, e a imediatamente acima e abaixo. A seguir, as mesmas foram lavadas com água destilada, secas em estufa a $65^{\circ} \mathrm{C}$ até peso constante, posteriormente moídas em moinho tipo Wiley, e acondicionadas em sacos de plástico.

O preparo das amostras e a análise química das folhas para a determinação dos teores de N, P, K, Ca, Mg, B, Zn, Fe, Cu e Mn foram realizadas no Laboratório de Análises Químicas de Solo e Tecido vegetal do CNPSo, Londrina-PR, segundo metodologia descrita por Sarruge \& Haag (1974). A obtenção do extrato para a determinação do $\mathrm{N}$ foi realizada através da digestão sulfúrica e a digestão nítrico-perclórica foi utilizada para a obtenção dos extratos para as determinações de $\mathrm{P}, \mathrm{K}, \mathrm{Ca}, \mathrm{Mg}, \mathrm{Cu}, \mathrm{Fe}, \mathrm{Mn}$ e $\mathrm{Zn}$. Para o B a amostra foi incinerada em mufla a $550^{\circ} \mathrm{C}$.

A determinação do $\mathrm{N}$ foi efetuada pelo método de Indofenol (Miyazawa et al., 1992). O fósforo foi determinado por colorimetria de vanadato molibdato; o K por fotometria de chama; o $\mathrm{Ca}, \mathrm{Mg}, \mathrm{Cu}, \mathrm{Fe}, \mathrm{Mn}$ e $\mathrm{Zn}$ por espectrofotometria de absorção atômica e o $B$ por colorimetria de azometina $H$.

O teor de óleo nos aquênios foi determinado em equipamento de ressonância magnética, modelo OXFORD 4000 NMR Magnet Analyser, no Laboratório de Análises Físico-Químicas do Melhoramento do CNPSo, Londrina-PR.

\subsubsection{Análise química do solo}

Após a coleta das plantas do experimento, o solo de todos os vasos foram destorroados e homogeneizado, seco ao ar e passado em peneira de 2 $\mathrm{mm}$. Foram coletadas amostras simples de terra de cada vaso para determinação dos teores de boro, conforme metodologia descrita no ítem 3.2. 


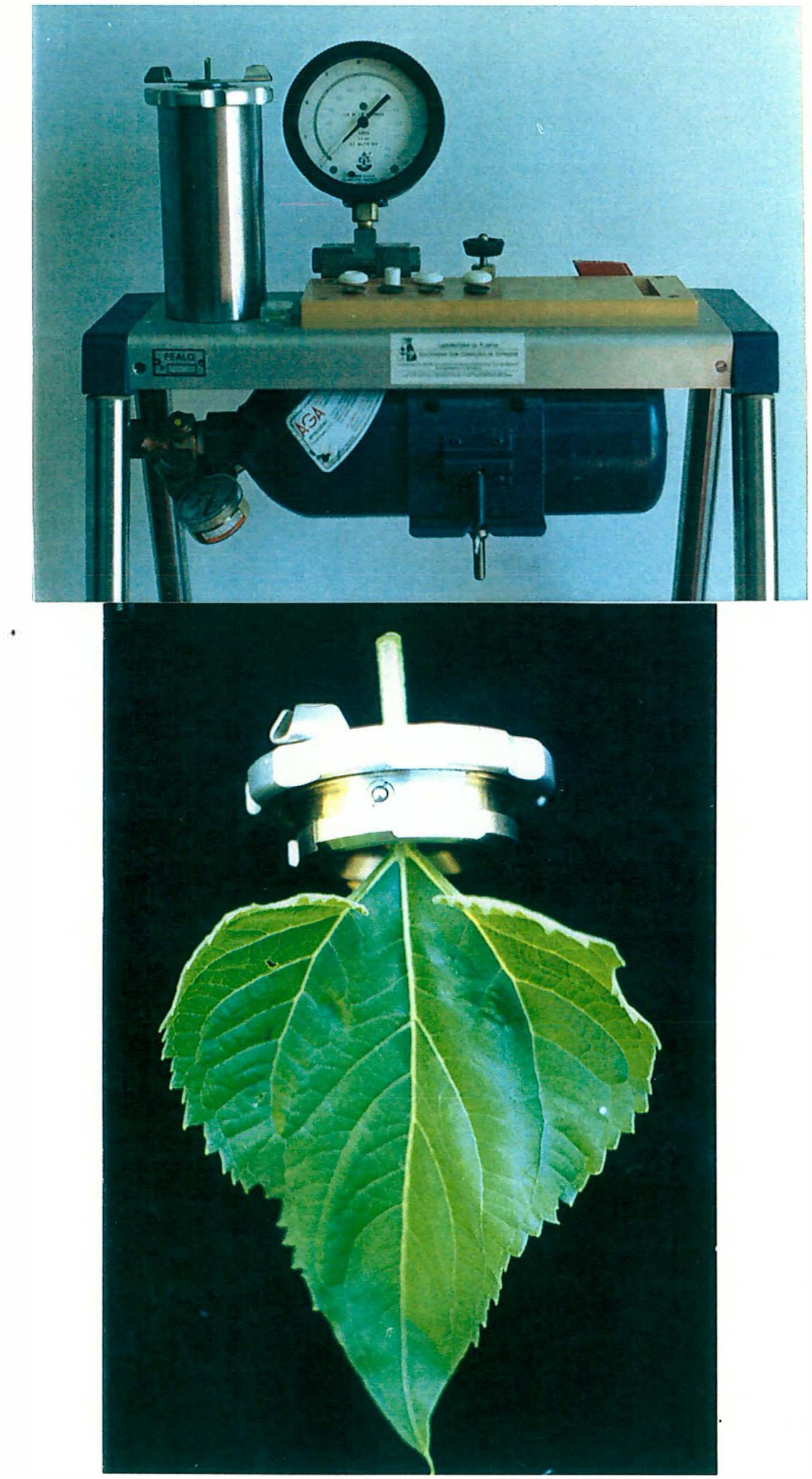

Figura 1. Câmara de pressão de Scholander, modelo PMS 1003. 


\section{RESULTADOS E DISCUSSÃO}

\subsection{Produção}

\subsubsection{Produção de matéria seca}

\subsubsection{Matéria seca total}

A análise de variância para a produção de matéria seca da parte aérea revelou significância $(p<0,01)$ para a interação entre doses de boro aplicadas no solo e fases de aplicação do estresse hídrico (Figura 2). As equações de Mitscherlich ajustaram-se aos dados de produção.

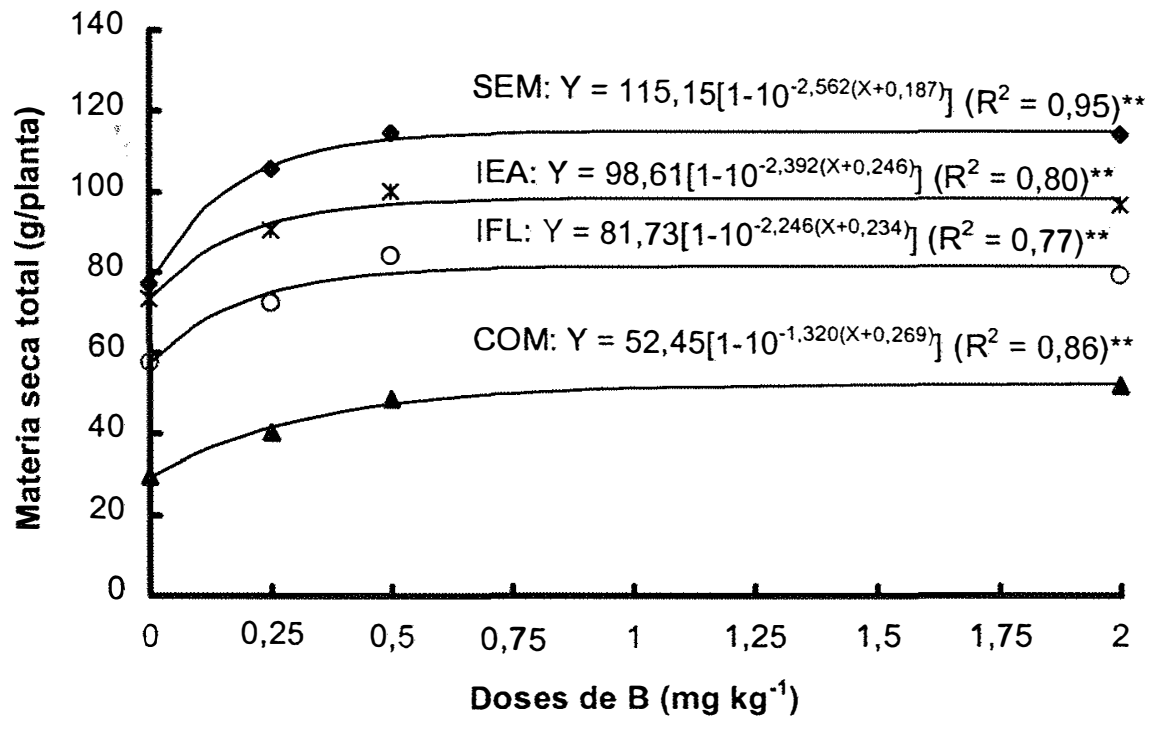

Figura 2. Produção de matéria seca total de plantas de girassol em função das doses de boro aplicadas no solo e fases de aplicação do estresse hídrico. 
$\mathrm{Na}$ equação são apresentados os valores de produção máxima teórica possivel de matéria seca total $(A)$, que não pode ser ultrapassada, em função da sua natureza assintótica horizontal, 115,2; 98,6; 81,7 e 52,4 g/planta para os tratamentos SEM, IEA, IFL e COM, respectivamente. O decréscimo significativo dos valores de produção representa a perda de matéria seca nos tratamentos, devido exclusivamente a restrição hídrica durante todo o ciclo (COM) ou em fases críticas para as culturas (IFL e IEA).

O termo (b) da equação pode ser interpretado como o teor de boro previamente existente no solo, para atender a produção de matéria seca, sem adição de fonte externa do nutriente, ou seja, na dose de 0,0 de B. Nos tratamentos IEA, IFL e COM foi 0,$246 ; 0,234$ e $0,269 \mathrm{mg} \mathrm{kg}^{-1}$ de $B$, respectivamente. Estes valores são próximos ou mesmo coincidentes com aqueles estimados pelo método da água quente, obtido no florescimento (Tabela 5) ou na colheita (Figura 34). No tratamento SEM, este valor foi de $0,188 \mathrm{mg} \mathrm{kg}^{-1}$ de B. Esta diferença, principalmente entre o tratamento SEM e COM, indica que enquanto para sustentar a produção de $29,3 \mathrm{~g}$ de matéria seca no tratamento COM era necessário $0,269 \mathrm{mg} \mathrm{kg}^{-1}$ de $B$ no solo; no tratamento SEM, com $0,188 \mathrm{mg} \mathrm{kg}^{-1}$ de $B$ no solo, sustentava uma produção significativamente maior de 77,1g de matéria seca. Esta diferença, demonstra a importância da água na absorção e metabolismo do boro pelas plantas.

O parâmetro (c) da equação, conhecido como coeficiente de eficácia do nutriente ( $\mathrm{kg}$ de solo por $\mathrm{mg}$ de $\mathrm{B}$ ) indica a velocidade de resposta da planta, em termos de produção, às doses adicionais do nutriente no solo. Nas condições específicas do experimento indica que no tratamento SEM, foi obtido a maior velocidade de resposta às doses de $\mathrm{B}$ com 2,56 $\mathrm{kg}$ de solo por $\mathrm{mg}$ de $B$, enquanto no tratamento COM foi obtido somente $1,32 \mathrm{~kg}$ de solo por $\mathrm{mg}$ de B. Este comportamento é concordante com o foi observado nas plantas destes tratamentos e demonstra que a falta de água diminui a eficiência das plantas no aproveitamento do boro disponivel do solo. 
$\mathrm{Na}$ Figura 2 observa-se que as doses de boro influenciaram, de forma semelhante, a produção de matéria seca total em todas as fases de aplicação do estresse hídrico. Apesar das curvas de produção apresentarem a mesma tendência em relação às doses de boro, as fases de aplicação do estresse hídrico influenciaram a produção de matéria seca total, com as maiores produções ocorrendo sempre em função da maior disponibilidade de água. Esta observação é importante pois demonstra que apesar das plantas responderem às doses de $B$, mesmo sob condições hídricas desfavoráveis, foi a água o fator determinante na produção.

$\mathrm{Na}$ Tabela 10, observa-se que na dose 0,0 de boro as plantas dos tratamentos SEM e IEA foram significativamente superiores aos demais. Esta constatação enfatiza que na ausência da aplicação deste nutriente, o déficit de água só não reduziu o desenvolvimento das plantas no tratamento IEA. Nas demais doses de boro, a restrição hídrica em qualquer fase de aplicação do estresse hídrico, reduziu significativamente a produção de matéria seca total.

Tabela 10. Produção de matéria seca total de plantas de girassol em função das doses de boro e fases de aplicação do estresse hídrico.

\begin{tabular}{|c|c|c|c|c|c|}
\hline \multirow[b]{2}{*}{ Tratamentos } & \multicolumn{4}{|c|}{ Doses de boro $\left(\mathrm{mg} \mathrm{kg}^{-1}\right)$} & \multirow{2}{*}{ Média } \\
\hline & 0,0 & 0,25 & 0,50 & 2,00 & \\
\hline & & & din & & \\
\hline SEM & $77,18 \mathrm{a}$ & $105,79 a$ & $114,61 \mathrm{a}$ & $114,29 a$ & $102,97 \mathrm{~A}$ \\
\hline IEA & $73,40 a$ & $90,61 \mathrm{~b}$ & $100,13 b$ & $96,85 \mathrm{~b}$ & $90,25 \mathrm{~B}$ \\
\hline IFL & $57,62 b$ & $72,69 \mathrm{c}$ & $84,13 \mathrm{c}$ & $79,48 \mathrm{c}$ & $73,48 \quad 0$ \\
\hline COM & $29,62 c$ & $40,43 d$ & $48,71 d$ & $52,00 \mathrm{~d}$ & $42,69 \quad \mathrm{D}$ \\
\hline Média & 59,45 & 77,38 & 86,89 & 85,66 & 77,35 \\
\hline
\end{tabular}

CV $(\%) \quad 6,07$

D.M.S. (1\%) Média de Fase 5,47

D.M.S. (1\%) Doses/Fase 10,94

- Médias seguidas pelas mesmas letras na coluna não diferem entre si pelo teste de Tukey, ao nivel de $1 \%$ de probabilidade. 


\subsubsection{Matéria seca da parte aérea}

As doses de boro afetaram significativamente $(p<0,01)$ o acúmulo de matéria seca da parte aérea do girassol (Figura 3). Derivando-se a equação de regressão, verifica-se que a obtenção de $90 \%$ da produção máxima seria atingida na dose de $0,37 \mathrm{mg} \mathrm{kg}^{-1}$ de boro aplicada no solo, sendo esta, superior àquela obtida por Ruy (1986), de $0,2 \mathrm{mg} \mathrm{kg}^{-1}$, trabalhando com girassol em vaso, em cinco solos do Estado de São Paulo. É importante ressaltar, que neste trabalho, o autor promoveu a coleta aos 44 dias após a semeadura, ou seja, aproximadamente 40 dias após a emergência das plantas. Neste período, as plantas poderiam não ter demandado todas as necessidades de boro, podendo comprometer as demais fases de desenvolvimento e produção da cultura e portanto subestimando as necessidades nutricionais da cultura.

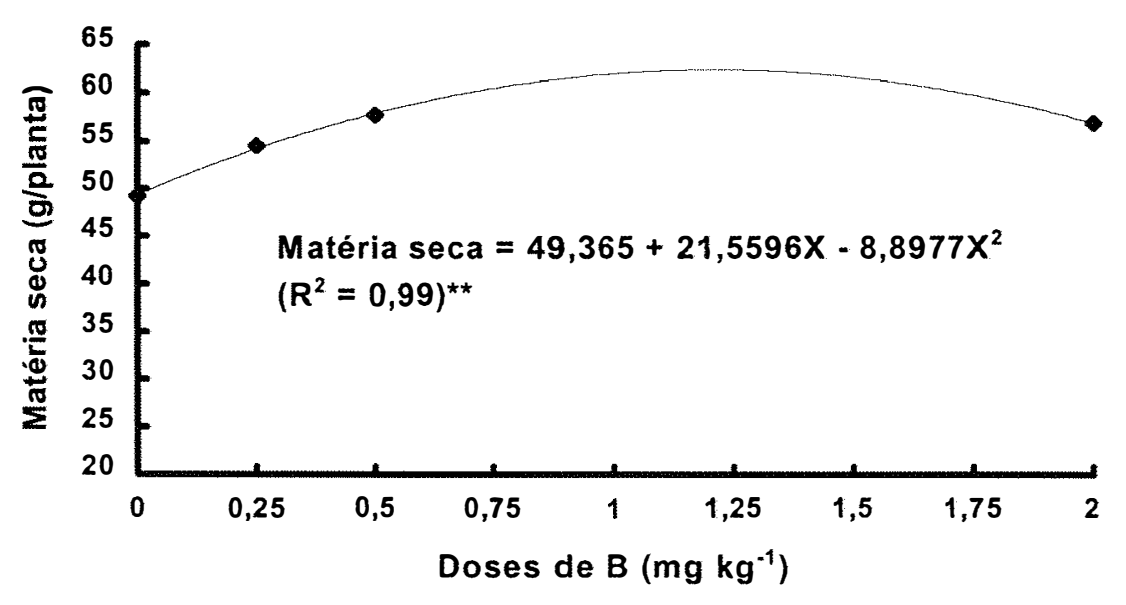

Figura 3. Peso da matéria seca da parte aérea de plantas de girassol em função de doses de boro aplicadas no solo.

Observando a Figura 3, verifica-se que nas plantas do tratamento 0,0 de boro, o peso da matéria seca foi relativamente alto em relação as demais doses, apesar das plantas apresentarem nítidos sintomas de deficiência do 
nutriente, o que também foi observado por Baumgartner et al. (1986), trabalhando com girassol em solução nutritiva. Entretanto, apesar do peso alcançado, uma avaliação baseada apenas neste parâmetro pode induzir a erro de julgamento, visto que o mesmo comportamento não ocorreu com a produção de aquênios, que foi significativamente inferior as demais. Este fato demonstra que a deficiência de boro prejudica mais seriamente a produção de aquênios que a produção de fitomassa.

Os resultados de produção da matéria seca em função das fases de aplicação do estresse hídrico variaram significativamente $(p<0,01)$, como apresentado na Figura 4, demonstrando queda no desenvolvimento das plantas em resposta a redução na disponibilidade hídrica. As plantas do tratamento SEM, mantidas durante todo o ciclo sem restrição hídrica, podendo, portanto, serem utilizadas como padrão de desenvolvimento, apresentaram produção significativamente superior a todos os demais tratamentos.

$\mathrm{Na}$ Figura 4, evidencia-se que a restrição hídrica às plantas a partir do início do florescimento (IFL) afetou mais seriamente a produção de matéria seca do que a partir do início de enchimento de aquênios (IEA). As plantas do tratamento COM, apresentaram produção de matéria seca significativamente inferior a todos os demais tratamentos.

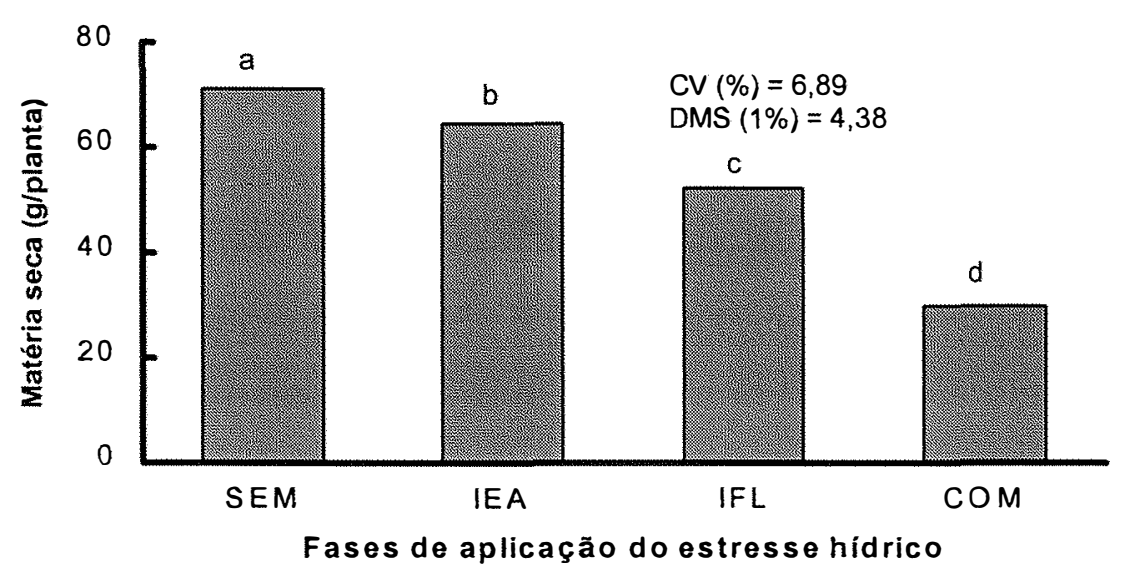

Figura 4. Produção de matéria seca da parte aérea de plantas de girassol em função das fases de aplicação do estresse hídrico. 


\subsubsection{Matéria seca de raiz}

A produção de matéria seca de raiz não foi alterada significativamente $(p>0,05)$ pelas doses de boro aplicadas no solo (Apêndice 2). Este comportamento foi contrário ao ocorrido com o peso de matéria seca total e da parte aérea das plantas. Entretanto, avaliando-se separadamente os resultados de produção relativos ao tratamento SEM observa-se na maior dose de $B$ tendência de queda de produção. No entanto, na mesma dose de $B$, a produção de matéria seca total e de aquênios não diminuiu. Provavelmente, em função da disponibilidade de água e nutrientes o sistema radicular teve menor participação na composição da produção de matéria seca total, não tendo havido portanto, necessidade de expansão do mesmo, para suprir às necessidade de crescimento destas plantas.

A análise de variância da produção da matéria seca das raízes mostrou significância $(p<0,01)$ para as fases de aplicação de estresse hídrico. Ao contrário do comportamento das plantas em relação à produção de matéria seca da parte aérea, não houve diferença significativa na matéria seca das raízes das plantas dos tratamentos SEM e IEA, com 10,9 g/vaso e 10,62 g/planta, respectivamente (Figura 5). Esta constatação reforça a idéia de que a parte aérea é mais seriamente afetada pelo estresse hídrico do que o sistema radicular. Este fato é explicado pela diferença de potencial. Enquanto a diferença de potencial hídrico entre solo e raiz está em torno de 0,1 $\mathrm{MPa}$, entre o xilema da folha e a atmosfera está ao redor de $100 \mathrm{MPa}$ (Taiz \& Zeiger, 1998). Portanto, são as folhas que estão em contato mais direto aos efeitos do estresse hídrico e consequentemente mais sofrem seus efeitos.

Apesar da diferença estatística dos tratamentos SEM/IEA em relação aos demais, o que se ressalta é a grande diferença entre a produção de matéria seca das raízes das plantas dos tratamentos IFL e COM, 8,98 e 3,58 g de raiz/planta, respectivamente, destacando o quanto foi afetado pela falta de água o último tratamento. 


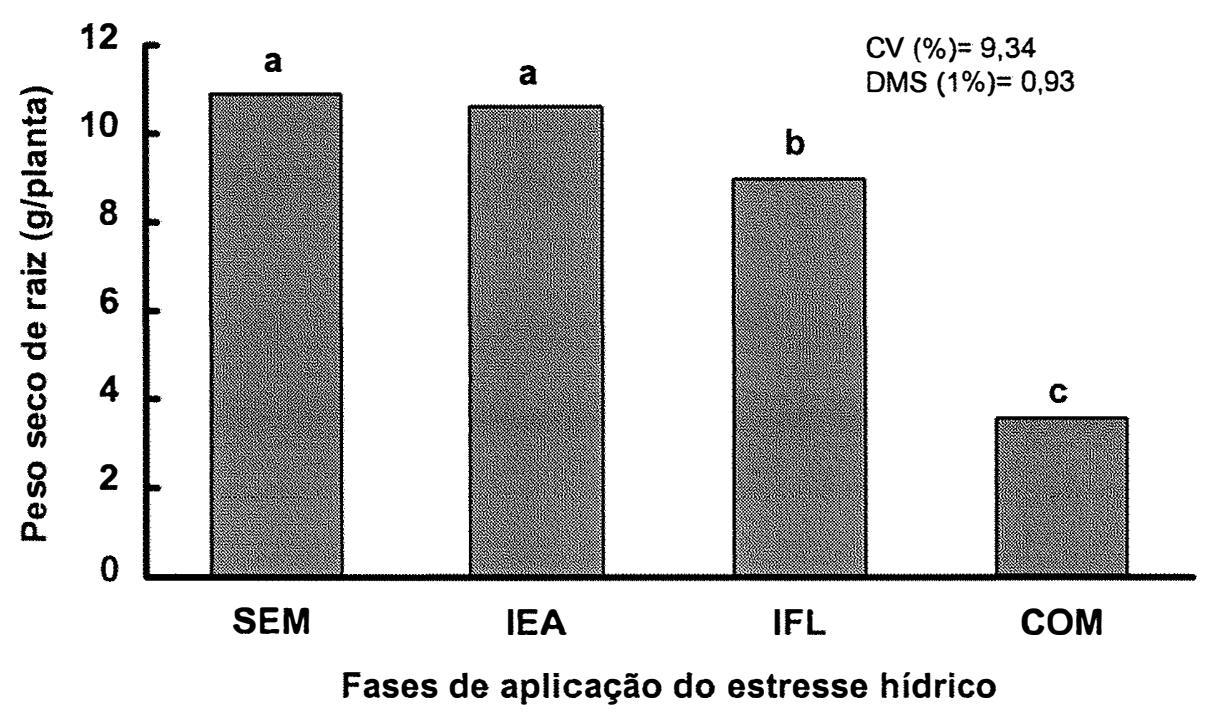

Figura 5. Peso da matéria seca de raízes de girassol em função das fases de aplicação do estresse hídrico.

\subsection{3.1 Relação matéria seca de raiz e matéria seca da fitomassa total}

A relação entre matéria seca de raiz e fitomassa total das plantas foi afetada significativamente pelas doses de boro aplicadas no solo $(p<0,01) \mathrm{com}$ ajuste ao modelo quadrático de regressão

$\mathrm{Na}$ dose 0,0 de boro foi observada maior participação das raízes nesta relação, alcançando 0,14 . Nas demais doses houve queda nesta relação, até a dose de $1,25 \mathrm{mg} \mathrm{kg}^{-1}$ de $B$ aplicada no solo. O comportamento da curva foi devido a falta de resposta das raízes às doses de $B$; enquanto a produção de matéria seca da parte aérea ajustou-se a uma equação do segundo grau. Sendo assim, na dose de 0,0 de $B$, o sistema radicular teve, proporcionalmente, maior desenvolvimento em relação a parte aérea, que as demais doses de B. Este comportamento, provavelmente pode ter sido para aumentar a absorção de nutrientes, e atender o desenvolvimento da parte aérea (Figuras 6). 


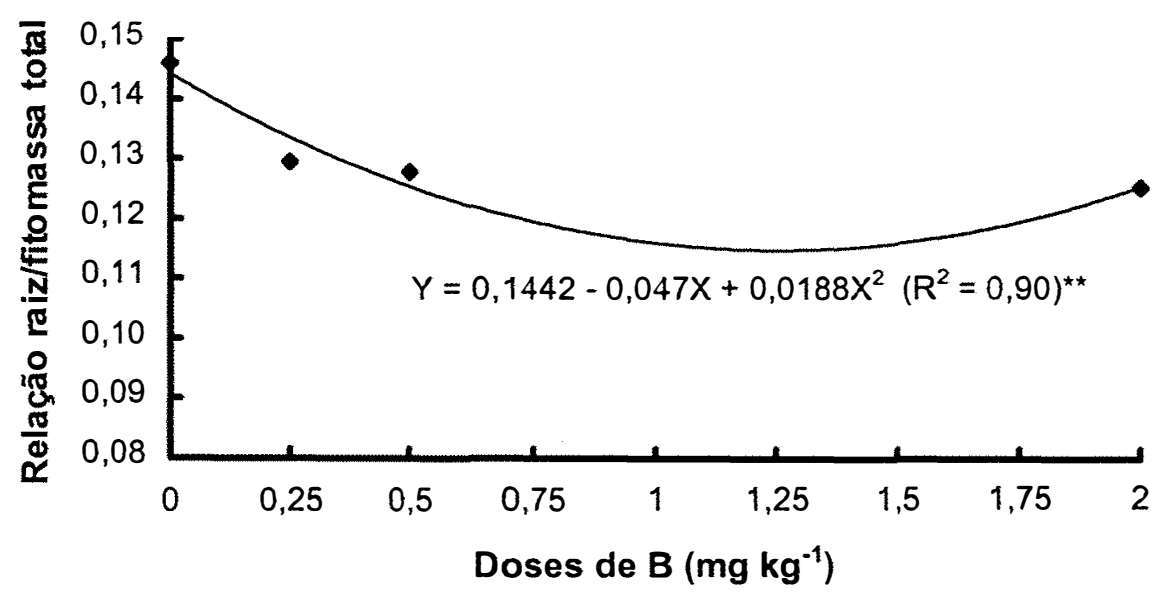

Figura 6. Relação matéria seca de raízes e fitomassa total em função das doses de boro aplicadas no solo.

Os resultados da relação raiz/fitomassa total em função das fases de aplicação do estresse hídrico variaram significativamente $(p<0,01)$, conforme mostrado na Figura 7.

O tratamento COM foi inferior a todos os demais, o que a princípio, é um resultado contrário às observações de diversos autores (Blum \& Arkin, 1984; Belhassen, 1996 e Asseng et al., 1998), uma vez que o desenvolvimento do estresse hídrico proporcionaria maior deslocamento de reservas de carboidratos para as raízes, em prejuizo da parte aérea. Entretanto, às condições de condução do experimento, podem não ter possibilitado este modelo de partição de fotoassimilados. No experimento, as plantas estavam confinadas em vasos de $10 \mathrm{~kg}$ de solo, com restrição da disponibilidade de água e a noite, quando a evapotranspiração era praticamente nula, ausência de movimentação de água por capilaridade.

As plantas do tratamento IFL $(0,15)$ apresentaram maior participação das raízes na fitomassa total (Figura 7 ) em relação às plantas dos tratamentos $\operatorname{SEM}(0,13)$ e $\operatorname{COM}(0,11)$. 
O tratamento SEM, apesar de ter proporcionado o maior desenvolvimento da matéria seca total, da parte aérea, das raízes e de aquênios (Figuras 2, 4, 5 e 10) não foi aquele de maior produção relativa de raízes. Isto se deve ao fato de que, apesar do maior desenvolvimento da parte aérea e das raízes, o crescimento da parte aérea foi, em termos absolutos, muito superior ao dos demais tratamentos, consequentemente diminuindo a relação considerada.

Esta constatação demonstra que, sob condições adequadas de disponibilidade hídrica e de nutrientes, o desenvolvimento do sistema radicular não apresenta a mesma importância quando em condições adversas, situação em que o desenvolvimento e a exploração de um grande volume de solo são determinantes no estabelecimento e crescimento das plantas.

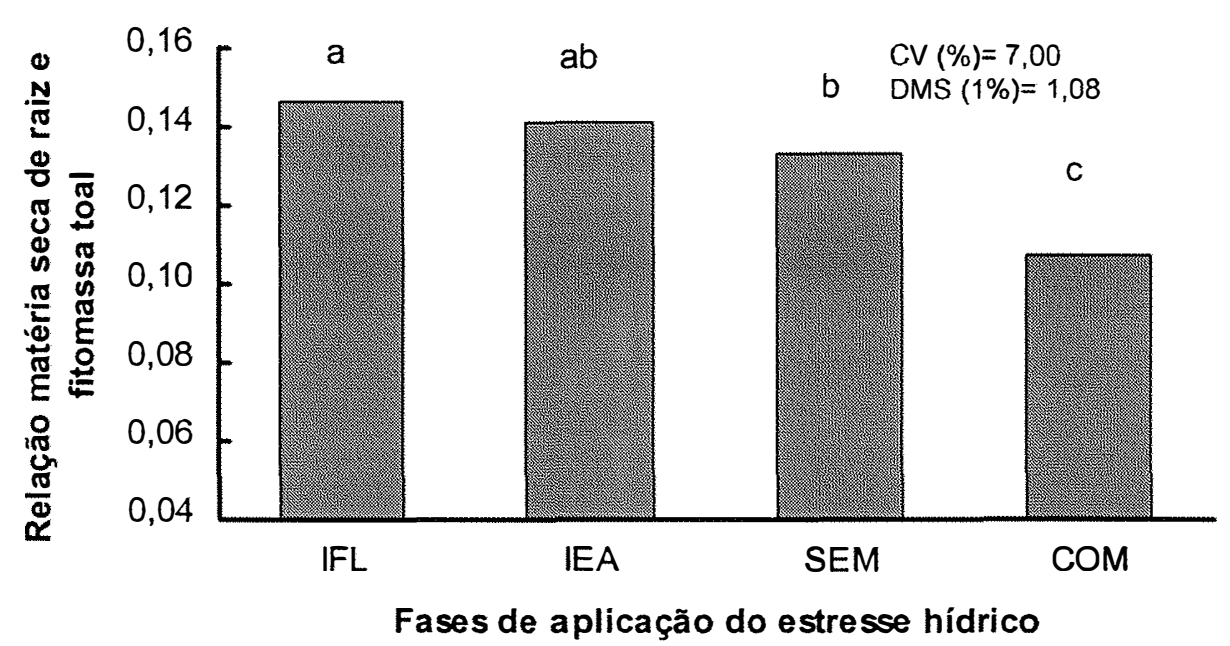

Figura 7. Relação matéria seca de raízes e fitomassa total em função das fases de aplicação do estresse hídrico.

Observando-se a dinâmica de evolução da relação do sistema radicular ao longo do experimento aos 35,54, 65, 77 e 89 dias (Tabela 11), verifica-se que aos 35 dias, a relação raízes/fitomassa total foi de 0,23 nos tratamentos 
SEM/IFL/IEA, o que de modo geral, está de acordo com os valores citados por (Merrien, 1992), enquanto o tratamento COM alcançou 0,26 valor ligeiramente acima do citado pelo mesmo autor. A diferença entre os tratamentos foi provavelmente devido a mudança da relação raiz/parte aérea no tratamento COM, para atender o estabelecimento, sobrevivência e crescimento destas plantas, mantidas durante todo o ciclo sob condições de estresse hídrico, estando em concordância com as observações de Blum \& Arkin (1984) e Belhassen (1996).

No girassol colhido aos 54 dias, a relação raiz/fitomassa total dos tratamentos SEM/IFL/IEA era de 0,15 , enquanto o tratamento COM 0,17. Esta redução da relação entre os 35 dias e 54 dias, já era esperada, uma vez que no início do desenvolvimento das plantas o crescimento do sistema radicular é mais acelerado que o da parte aérea.

Aos 65 dias, a relação raiz/fitomassa total foi de 0,14 e de 0,16 nos tratamentos SEM/IFL/IEA e COM, respectivamente, mostrando menor participação das raízes em relação ao início do ciclo da cultura. Porém, apesar da redução, nas plantas do tratamento COM o desenvolvimento do sistema radicular ainda era maior que nos demais.

As plantas dos tratamentos SEM/IEA, aos 77 dias, apresentaram a mesma tendência de queda registrada anteriormente, alcançando 0,13. Nos tratamentos IFL e COM foi de 0,15 e 0,16, respectivamente. O tratamento IFL não apresentou a mesma tendência de queda, visto que a partir dos 65 dias, com a brusca imposição do estresse hídrico, o desenvolvimento da parte aérea, a partir desse periodo, foi drasticamente afetado (Figura 4).

No girassol colhido aos 89 dias, a relação raiz/fitomassa total do tratamento SEM era de 0,13 , estabilizando a tendência de queda. Por outro lado, no tratamento COM houve acentuada redução, atingindo somente 0,11. Neste tratamento, ao contrário do que poderia ser esperado, o sistema 
radicular durante o ciclo da cultura foi gradual e severamente reduzido em função da menor produção de raiz ao final do ciclo da cultura (Figura 5).

O comportamento das raízes foi, modo geral, concordante com os dados citados por Merrien (1992), afirmando que o sistema radicular tem uma forte taxa de crescimento no início do ciclo, que é mais importante que o da parte aérea, com a razão raiz/fitomassa total de 0,20 a 0,25. Para o mesmo autor, este valor é progressivamente reduzido para em torno de 0,15. Entretanto, tomando-se como base o tratamento SEM, que provavelmente foi a condição hídrica do experimento conduzido por Merrien (1992), observa-se na Tabela 11, que a redução foi mais acentuada que a citada.

A redução da relação raiz/fitomassa total nas plantas do tratamento COM pode ser explicada não só pelas condições de condução do experimento, como também pela maior taxa de mortalidade de raízes em relação a renovação destas, em virtude da restrição hídrica.

Tabela 11. Relação matéria seca de raiz e matéria seca da fitomassa total em diferentes períodos de coleta.

\begin{tabular}{ccccc}
\hline Período (dias) & SEM/IFL/IEA $^{*}$ & COM & IFL & IEA \\
\hline 35 & 0,23 & 0,26 & - & - \\
54 & 0,15 & 0,17 & - & - \\
65 & 0,14 & 0,16 & - & - \\
\hline & SEM/IEA $^{*}$ & COM & IFL & IEA \\
\hline 77 & 0,13 & 0,166 & 0,15 & - \\
\hline 89 & SEM & COM & IFL & IEA \\
\hline & 0,13 & 0,11 & 0,14 & 0,14
\end{tabular}

* As plantas dos tratamentos SEM/IEA/IFL e SEM/IEA foram tomadas em conjunto, pois ainda não estavam sob estresse hídrico. 


\subsection{2 Área foliar}

O estresse hídrico afetou seriamente o desenvolvimento da área foliar das plantas de girassol nos tratamentos sob condições de restrição de água, conforme pode ser observado nos dados agrupados na Tabela 12, nas quatro épocas distintas de coleta das folhas. A redução da área foliar em função do estresse hídrico nas plantas dos tratamentos COM e IFL, estão de acordo com as observações de diversos autores (Kramer, 1983; Hale \& Orcutt, 1987; Hopkins, 1995; Blum, 1997), visto que um dos primeiros efeitos do estresse hídrico é a redução do crescimento vegetativo, da área foliar, consequentemente do aparato fotossintético e, por extensão, do rendimento das culturas.

Tabela 12. Área foliar de plantas de girassol dos tratamentos SEM, IFL, IEA e COM nos períodos de desenvolvimento da cultura do girassol.

\begin{tabular}{|c|c|c|c|c|c|c|c|c|c|}
\hline \multirow{3}{*}{$\begin{array}{c}\text { Dose } \\
\text { B } \\
\mathrm{mg} \mathrm{kg}^{-1}\end{array}$} & \multicolumn{9}{|c|}{ Dias após a emergência } \\
\hline & \multicolumn{2}{|l|}{35} & \multicolumn{2}{|l|}{54} & \multicolumn{2}{|l|}{65} & \multicolumn{3}{|c|}{77} \\
\hline & SEM/IFL/IEA ${ }^{*}$ & $\overline{\operatorname{COM}}$ & SEM/IFL/IEA* & $\overline{C O M}$ & SEM/IFL/IE & $\overline{\mathrm{COM}}$ & SEM/IEA ${ }^{*}$ & $\overline{\mathrm{IFL}}$ & COM \\
\hline 0,00 & 1254 & 407 & 1619 & 862 & 1584 & 820 & 1593 & 1246 & 643 \\
\hline 0,25 & 1265 & 589 & 1740 & 706 & 1625 & 677 & 1687 & 1085 & 691 \\
\hline 0,50 & 1338 & 633 & 1792 & 866 & 1637 & 680 & 1784 & 1103 & 737 \\
\hline 2,00 & 1453 & 777 & 1746 & 841 & 1749 & 839 & 1722 & 990 & 763 \\
\hline Média & 1328 & 602 & 1724 & 819 & 1649 & 754 & 1697 & 1106 & 709 \\
\hline
\end{tabular}

* Plantas dos tratamentos SEM/IEA/IFL e SEM/IEA, foram tomadas em conjunto, pois ainda não estavam sob estresse hídrico.

Aos 35 dias ocorreu redução média de $54,7 \%$ da área foliar nas plantas do tratamento COM em relação ao conjunto dos tratamentos sem estresse 
hídrico (SEM/IFL/IEA). Aos 54 e 65 dias a redução foliar média em relação aos mesmos tratamentos foi de $52,5 \%$ e $54,3 \%$, respectivamente.

Aos 77 dias, os tratamentos IFL e COM apresentavam queda de 34,8 e $58,2 \%$, respectivamente, em relação aos tratamentos SEM/IEA. Apesar da redução de área foliar do tratamento IFL, o tratamento COM apresentava área foliar 35,9\% menor que a do IFL. É interessante observar que em 12 dias de redução da disponibilidade hídrica imposta ao tratamento IFL, entre os 65 e 77 dias, a redução média da área foliar alcançou $34,8 \%$. Esta queda demonstra a sensibilidade do desenvolvimento foliar do girassol ao estresse hídrico, concordando com as observações de Rawson et al. (1980) e Takami et al. (1981), que enfatizaram a sensibilidade do girassol ao estresse hídrico moderado.

A redução da área foliar que ocorreu nas plantas do tratamento IFL aos 77 dias, pode ser melhor entendida quando se observa o potencial hídrico das mesmas no período, entre -0,76 e -0,58 MPa (Tabela 9); podendo também ser deduzido que na época imediatamente após o início da imposição do estresse hídrico (65 dias), o potencial hídrico, era provavelmente menor (mais negativo). Como conseqüência direta da redução do potencial hídrico em função do estresse hídrico, o desenvolvimento foliar foi seriamente prejudicado, estando de acordo com o observado por Boyer (1970).

$\mathrm{Na}$ avaliação da área foliar, destacou-se a redução média nas plantas do tratamento $\mathrm{COM}$ em relação àqueles sem estresse hídrico, alcançando em média $55 \%$, bem como seu potencial hídrico, sempre mais negativo que os demais (Tabela 9) e portanto, afetando o desenvolvimento foliar e, por conseguinte, a produção de aquênios.

O efeito do estresse hídrico nas plantas dos tratamentos SEM, IFL e COM pode ser melhor entendido quando se compara a redução de área foliar medida até os 77 dias e a produção de aquênios aos 102 dias. Sendo assim, constata-se que, enquanto a redução da área foliar entre o tratamento SEM e 
COM era de $58,2 \%$, a redução da produção de aquênios entre os mesmos tratamentos era de $56,2 \%$. Entre os tratamentos SEM e IFL era de 34,8 e $42,3 \%$, enquanto que entre o IFL e COM era de 35,9 e $24,2 \%$, respectivamente. Deve ser observado que entre os tratamentos SEM e IFL, a redução de produção de aquênios foi maior que a da área foliar. Isto se deve ao fato de que enquanto a área foliar destes tratamentos foi determinada aos 77 dias, o estresse hídrico continuou afetando o desenvolvimento das plantas do tratamento IFL até os 102 dias, quando foi medida a produção de aquênio. O que se depreende das observações é que a menor disponibilidade de água às plantas e conseqüente redução do potencial hídrico e de pressão nas células das folhas, ocasionou menor desenvolvimento da área foliar, afetando seriamente a produção.

Embora não tenham sido feito as medidas de redução de área foliar a partir dos 77 dias, foi possivel deduzir que isto ocorreu, não só pela continuidade do estresse hídrico, mas também, pela comparação do peso de matéria seca da parte aérea dos tratamentos sob condições de estresse hídrico com aquele sem estresse, conforme pode ser constatado na Figura 4.

Como o aparato fotossintético, representado principalmente pelas folhas, responsável pela conversão de energia luminosa em energia química, crescimento e produção de biomassa, foi reduzido em função da imposição do estresse hídrico, a produção de aquênios foi também reduzida, conforme Figura 10. Segundo Cox \& Jolliff (1986), a expansão foliar do girassol é a característica vegetativa de crescimento mais sensivel ao estresse hídrico, sendo este comportamento também observado no experimento. 


\subsubsection{Altura de planta}

A análise de variância da altura das plantas demonstrou que houve diferença significativa $(p<0,01)$ para o efeito das doses de boro aplicadas no solo e para as fases de aplicação do estresse hídrico (Figura 8 e 9).

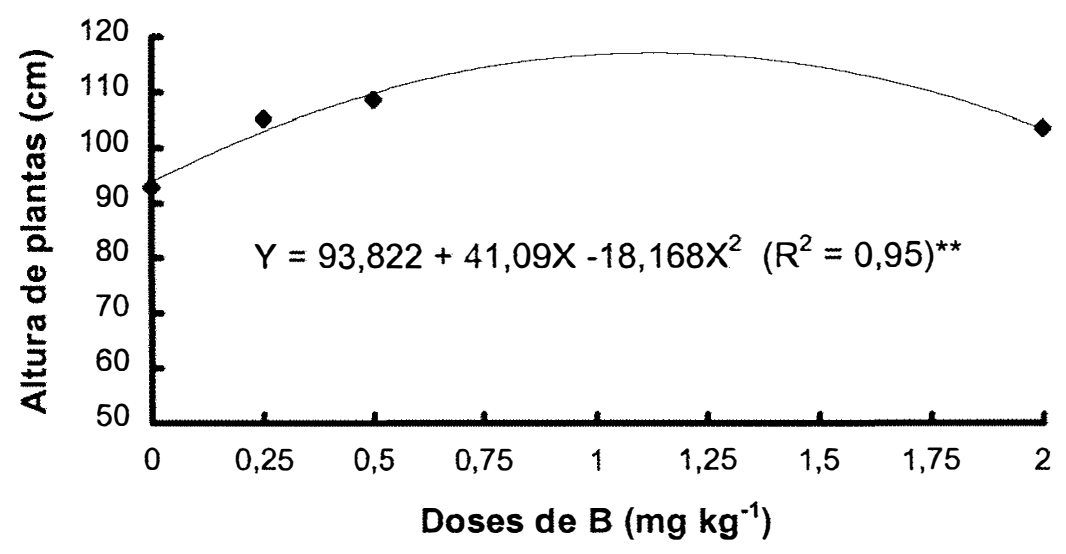

Figura 8. Altura de plantas de girassol em função das doses de boro aplicadas no solo.

Derivando-se a equação de regressão, verifica-se que $90 \%$ da altura máxima teria sido obtida com $0,33 \mathrm{mg} \mathrm{kg}^{-1}$ de boro aplicado no solo. Essa dose é intermediária àquelas encontradas por Casagrande (1978) e Ruy (1986), os quais observaram que teores acima de $0,4 \mathrm{mg} \mathrm{dm}^{-3}$ e $0,2 \mathrm{mg} \mathrm{dm}^{-3}$ de $B$ no solo, respectivamente, não proporcionavam maior altura das plantas; levando à conclusão de que tendo a altura de planta como parâmetro de crescimento, estes valores seriam suficientes para o desenvolvimento normal do girassol.

Na Figura 9 observa-se que as plantas dos tratamentos SEM, IEA e IFL apresentaram comportamento semelhante, atingindo altura média de $107,5 \mathrm{~cm}$, enquanto que as plantas do tratamento COM somente alcançaram $86,4 \mathrm{~cm}$. 


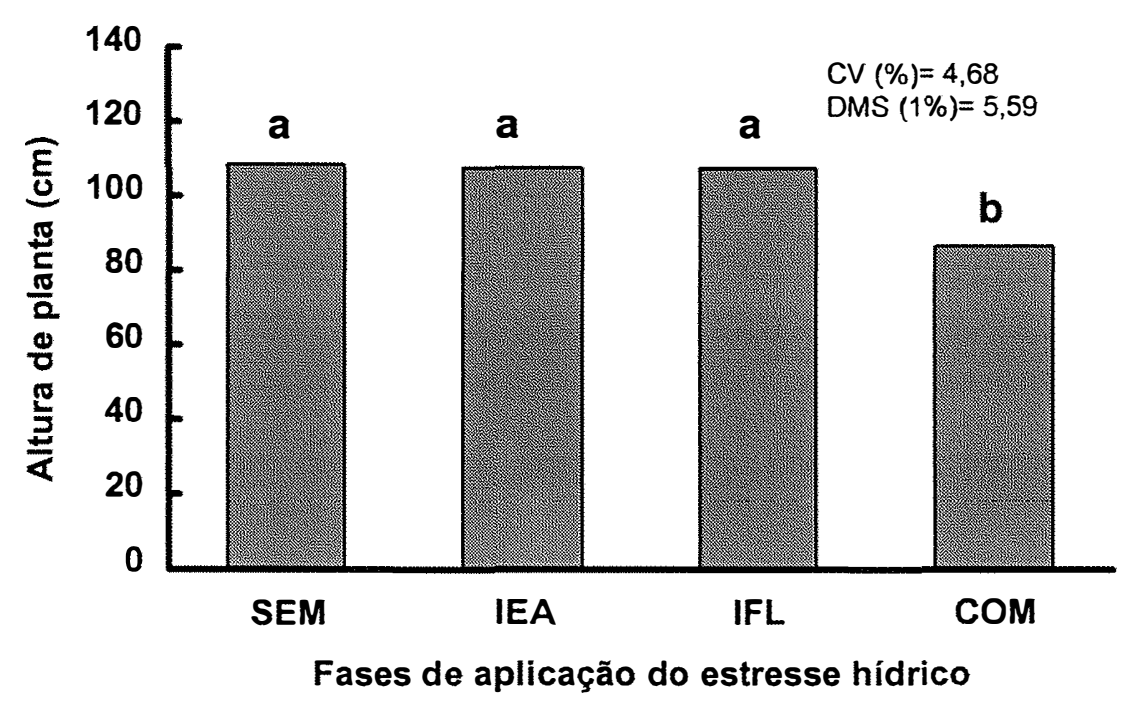

Figura 9. Altura média das plantas de girassol em função das fases de aplicação do estresse hídrico.

Apesar das plantas nos tratamentos SEM, IEA e IFL terem alcançado alturas semelhantes, o rendimento de aquênios e o de óleo foram afetados distintamente pela redução da disponibilidade de água. Sendo assim, a utilização da altura das plantas para avaliação do experimento, e possíveis inferências sobre o desenvolvimento futuro das plantas, nos tratamentos IEA e IFL, não seria o parâmetro mais adequado, uma vez que a produção de aquênios, que é o principal objetivo, não apresentou a mesma tendência, conforme constatado na Figura 10.

Segundo Casagrande (1978) e Ruy (1986), a altura média reflete melhor o estado nutricional do que o peso de matéria seca de plantas de girassol, sendo portanto um bom parâmetro de avaliação das plantas em relação ao boro. Ruy (1986), estudando quatro parâmetros de crescimento em função de doses de boro, confirmou que a altura das plantas é a medida da disponibilidade de boro mais sensível que os demais. 
Apesar da altura média das plantas realmente refletir, de modo geral, o estado nutricional do girassol, observou-se que esta e a produção de matéria seca são parâmetros que somente auxiliam a interpretação dos resultados finais de produção de aquênios, visto que, quando tomados ao redor dos 45 dias após a emergência das plantas, podem não refletir o estado nutricional das plantas na fase reprodutiva, quando a demanda de nutrientes é maior e determinante no rendimento final da cultura.

A questão do melhor parâmetro para avaliação do estado nutricional pode ser melhor observada quando compara-se o teor de boro no solo, suficiente para obtenção de $90 \%$ da altura máxima $0,33 \mathrm{mg} \mathrm{kg}^{-1}$, com o teor do nutriente para o mesmo nível de produção de aquênios (90\%), do tratamento SEM, que foi $0,46 \mathrm{mg} \mathrm{kg}^{-1}$ de $\mathrm{B}$. Com base nos dois teores, fica claro que a opção somente pela altura das plantas estaria subestimando a necessidade nutricional da cultura.

\subsubsection{Produção de aquênios}

A análise de variância da produção de aquênios das plantas de girassol demonstrou efeito significativo $(p<0,01)$ para a interação das doses de boro no solo e fases de aplicação do estresse hídrico (Figura 10). As equações Mitscherlich ajustaram-se aos dados de produção de aquênios.

A estimativa de $90 \%$ da produção máxima de aquênios nos tratamentos SEM, IEA, IFL e COM foi obtida nas doses de 0,46, 0,44, 0,39 e 0,56 mg kg-1 de $B$ no solo, respectivamente. Esses resultados permitem observar que as produções de aquênios responderam em função do aumento das doses de boro e da disponibilidade hídrica, estando de acordo com o esperado para a produção de grãos das culturas.

No tratamento COM, a obtenção de $90 \%$ da produção máxima de aquênios seria conseguida com $0,56 \mathrm{mg} \mathrm{kg}^{-1}$ de $B$ no solo, possibilitando a 
produção de $12,82 \mathrm{~g}$ de aquênio por planta, enquanto para o tratamento SEM, com a mesma dose de boro seria obtido $28,63 \mathrm{~g}$ de aquênio por planta. $\mathrm{O}$ incremento de $123 \%$ na produção ou de $114 \%$ considerando-se $90 \%$ da produção máxima para ambos os tratamentos, reflete não só a importância dos teores de boro no solo mas, fundamentalmente destaca o papel da disponibilidade hídrica na absorção do boro existente no solo e sua utilização no metabolismo celular e desenvolvimento das plantas.

Na Figura 10, fica evidente a importância da interação das doses de boro e da disponibilidade de água na produção final de aquênios. Esta constatação está de acordo com Viets ${ }^{4}$, citado por Kramer (1983), pois o mesmo menciona que a deficiência de minerais raramente é a causa da redução do crescimento em plantas estressadas. A única exceção deve ser a deficiência de boro em solos já deficientes no elemento. O mesmo autor ressalta que em condição de estresse hídrico, os teores do elemento no solo têm efeito relativo, mascarado talvez pela sua menor disponibilidade às plantas, já que nas mesmas doses do elemento, a produção aumentava em função do acréscimo da disponibilidade hídrica; comportamento também observado no experimento.

A menor produção dos tratamentos COM, IFL e IEA em função da restrição hídrica, pode ser explicada pela necessidade de redução da transpiração nessas plantas, além da reduzida absorção de íons pela menor mobilidade mineral, pelo decréscimo do volume de solo explorado pelo sistema radicular, bem como da redução da permeabilidade radicular (Kramer, 1983).

\footnotetext{
${ }^{4}$ VIETS, F.G.Jr. Waterdeficits and nutrient availability. In: KOZLOWSKI, T.T. (Ed). Water deficts and plant growth. New York: Academic Press, 1972. v.4, p.217-239.
} 


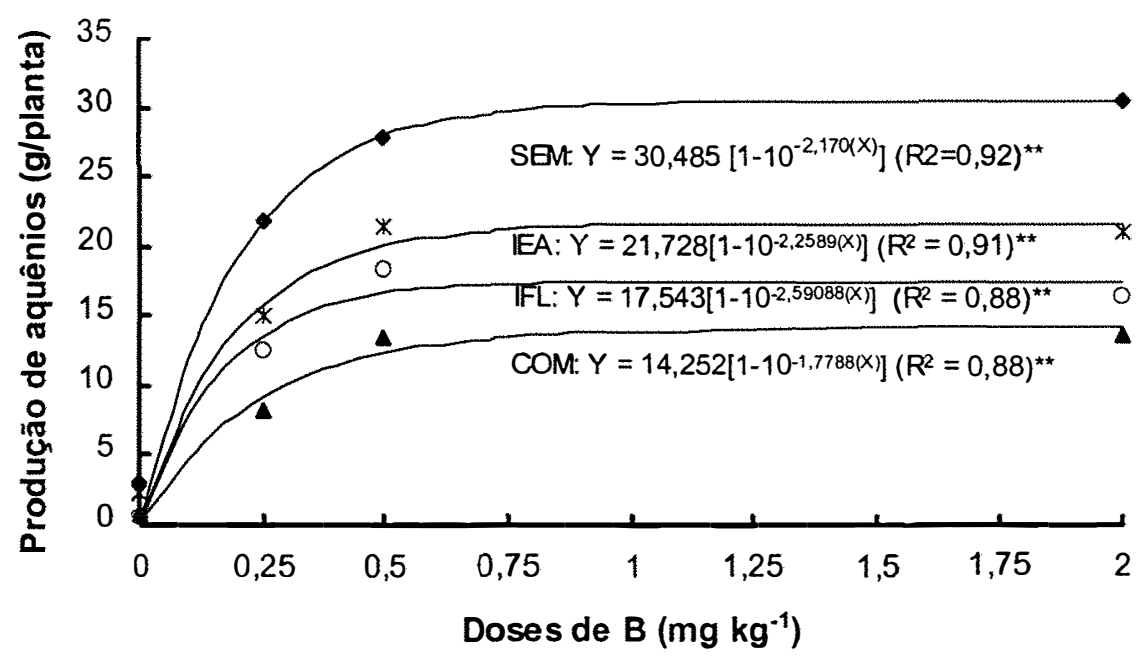

Figura 10. Produção de aquênios em função das doses de boro e fases de aplicação de estresse hídrico.

Na Figura 10, observa-se que o parâmetro b da equação de Mitscherlich é igual a zero, e representa o teor do nutriente disponível no solo às plantas. Esta constatação demonstra que apesar da existência de boro no solo, capaz de sustentar a produção de matéria seca total com a dose 0,0 de B (Figura 3), não foi suficiente para atender a produção de aquênios, sem a adição de fonte externa do nutriente. Em função dos teores de óleo e proteína existente nos aquênios de girassol, pode-se entender que o custo energético para a produção de aquênios é maior que aquele necessário para a produção de fitomassa total. O coeficiente de eficácia (c) do tratamento COM foi o menor de todos, indicando a menor velocidade de resposta dessas plantas às doses de boro aplicadas no solo, enquanto o tratamento IFL apresentou o maior coeficiente $\left(2,59 \mathrm{~kg} \mathrm{mg}^{-1}\right)$.

Utilizando-se as mesmas doses de boro no solo $(0,46,0,44,0,39$ e 0,56 $\mathrm{mg} \mathrm{kg}^{-1}$ ) correspondentes a $90 \%$ da produção máxima de aquênios dos tratamentos SEM, IEA, IFL e COM, respectivamente, e aplicando-as nas 
equações de regressão da Figura 2, obtém-se a produção de matéria seca total nas respectivas fases, permitindo o cálculo do Índice de Colheita.

$$
I C=\frac{\text { PesodeAquênios }}{\text { MSTotal }}
$$

Observa-se na Tabela 13 que apenas o tratamento COM, que alcançou o IC de 0,27 enquadra-se nos valores médios do IC do girassol 0,25 a 0,35, citado por Merrien (1992). Este autor cita que o IC do girassol é baixo, sendo assim, é interessante notar que, foi o tratamento COM, que apresentou o maior valor. Sendo assim, com base neste índice calculado, verifica-se que o tratamento COM foi o mais eficiente.

O maior IC das plantas do tratamento COM, apesar da drástica redução da produção de aquênios, pode ser explicado pela maior redução da fitomassa total, em relação aos demais tratamentos. Outra interpretação, pode ter sido em função dos maiores teores de nutrientes nas folhas, possibilitando maior redistribuicão no florescimento e enchimento de aquênios, aumentando, relativamente aos demais, a produção de aquênios. No tratamento SEM o IC de 0,24 foi devido a maior produção de fitomassa total, em relação aos demais tratamentos. O menor índice registrado nos tratamentos IEA e IFL, foi devido a redução da disponibilidade hídrica em fases críticas da cultura, indicando portanto, redução na eficiência de produção de aquênios.

Tabela 13. Índice de colheita nas fases de aplicação do estresse hídrico.

\begin{tabular}{cccc}
\hline Fases & Aquênios $(\mathrm{g})$ & Matéria seca total $(\mathrm{g})$ & Indice de Colheita* \\
\hline SEM & 27,43 & 112,63 & 0,24 \\
IEA & 19,56 & 96,36 & 0,20 \\
IFL & 15,79 & 78,47 & 0,20 \\
COM & 12,82 & 48,24 & 0,27 \\
\hline \hline
\end{tabular}

* Razão entre $90 \%$ da produção máxima de aquênios e da produção da matéria seca total, estimadas com base nas respectivas doses de boro. 
Respostas semelhantes ao comportamento das plantas dos tratamentos SEM e COM foram as obtidas por Cox \& Jolliff (1986), que trabalharam com girassol durante dois anos a campo e observaram que o déficit de água não afetou o IC, alcançando valores de $0,31,0,30$ e 0,29 para os tratamentos estresse severo, moderado e sem estresse hídrico, respectivamente.

Analisando-se a produção de aquênios em função das doses de $\mathrm{B}$ e fases de aplicação do estresse hídrico na Tabela 14, observa-se que na dose 0,0 de $B$ as produções foram muito baixas, demonstrando que os teores inicialmente existentes no solo não seriam suficientes para sustentar a produção de aquênios, independente da condição hídrica. Nas demais doses, as produções aumentaram não só em função do nutriente disponível no solo, mas fundamentalmente em estreita relação com a disponibilidade de água.

Tabela 14. Produção de aquênios em função das doses de boro e fases de aplicação do estresse hídrico.

\begin{tabular}{|c|c|c|c|c|c|}
\hline \multirow[b]{2}{*}{ Tratamentos } & \multicolumn{4}{|c|}{ Doses de boro $\left(\mathrm{mg} \mathrm{kg}^{-1}\right)$} & \multirow{2}{*}{ Média } \\
\hline & 0,0 & 0,25 & 0,50 & 2,00 & \\
\hline SEM & $2,99 a$ & $21,77 a$ & $27,94 a$ & $30,50 \mathrm{a}$ & $20,80 \mathrm{~A}$ \\
\hline IEA & $2,32 \mathrm{a}$ & $15,09 b$ & $21,43 b$ & $21,03 \mathrm{~b}$ & $14,99 \mathrm{~B}$ \\
\hline IFL & $0,55 a$ & $12,61 \mathrm{bc}$ & $18,35 \mathrm{bc}$ & $16,52 \mathrm{bc}$ & $12,01 \mathrm{C}$ \\
\hline COM & $0,76 \mathrm{a}$ & $8,31 \quad c$ & $13,57 \quad c$ & $13,77 \quad c$ & $9,10 \mathrm{C}$ \\
\hline Média & 1,65 & 14,44 & 20,32 & 20,46 & 14,22 \\
\hline
\end{tabular}

CV (\%)

18,09

D.M.S. (1\%) Média de Fase 2,97

D.M.S. (1\%) Fase dentro de dose 5,99

- Médias seguidas pelas mesmas letras na coluna não diferem entre si pelo teste de Tukey, ao nivel de $1 \%$ de probabilidade. 
Com base na Figura 10 e Tabela 14, verifica-se que a época mais crítica à deficiência de água na cultura do girassol, afetando mais seriamente a produção de aquênios, foi aquela em que o estresse hídrico foi imposto a partir do início do florescimento, seguida pela fase de enchimento de aquênios, o que está de acordo com a observação de Vranceanu (1977).

\subsubsection{Número de aquênios}

O número de aquênios foi afetado significativamente $(p<0,01)$ pelas doses de boro aplicadas no solo e fases de aplicação do estresse hídrico. $O$ maior número foi obtido nas doses 2,0 e $0,5 \mathrm{mg} \mathrm{kg}^{-1}$ de $B$ aplicadas no solo, com 476 e 445, seguida das doses 0,25 e $0,0 \mathrm{mg} \mathrm{dm}^{-3}$ de $B$ com 335 e 43 aquênios por capítulo, respectivamente (Figura 11).

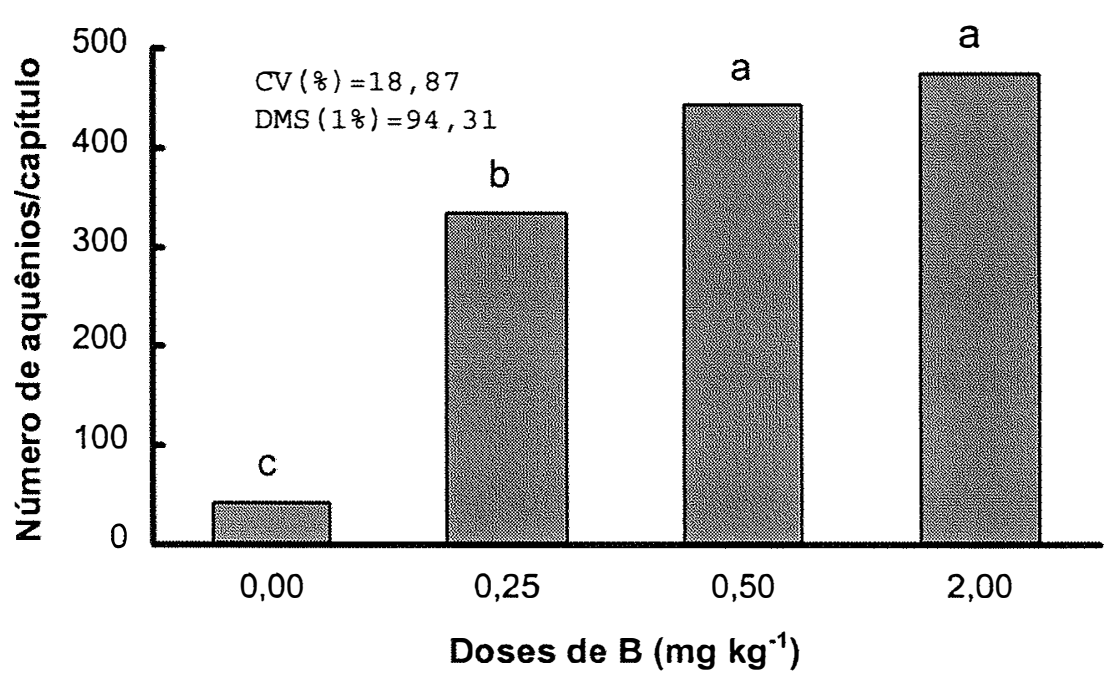

Figura 11. Número de aquênios por capítulo em função das doses de boro aplicada no solo.

Na Figura 12 observa-se haver elevado coeficiente de correlação entre o número e a produção de aquênios por capítulo. Esta correlação evidencia que 
o número aquênios é um parâmetros adequado para avaliar a produção final do girassol.

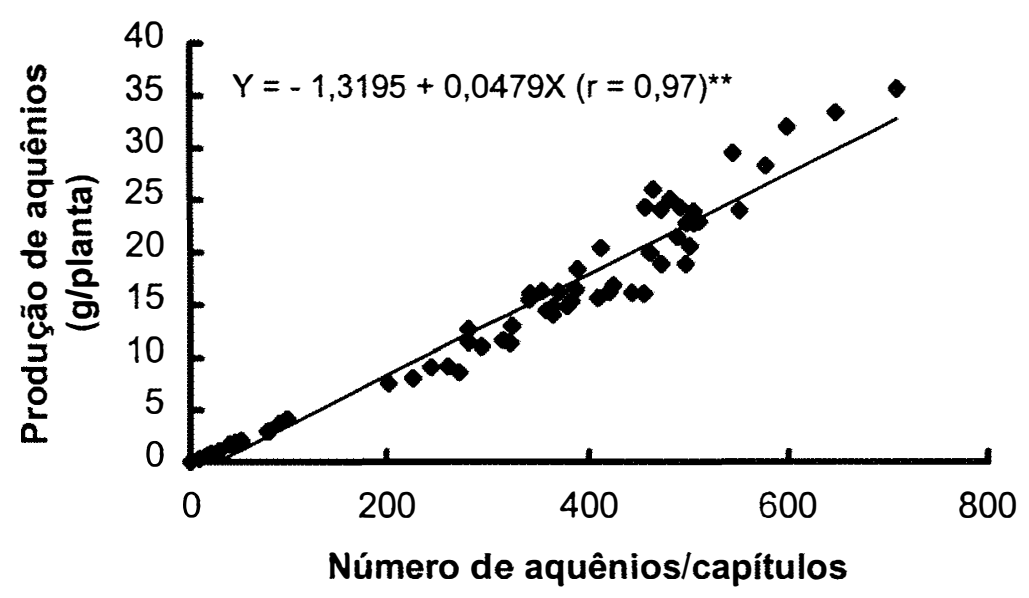

Figura 12. Correlação entre número de aquênios por capítulos e a produção de aquênios.

O número de aquênios por capítulo em função das fases de aplicação do estresse hídrico é apresentado na Figura 13. O tratamento SEM foi superior a todos os demais, enquanto o tratamento COM, teve menor produção que os tratamentos SEM e IEA.

Foi observado que o número de aquênios foi uma função direta da disponibilidade de água às plantas. Este comportamento foi semelhante ao obtido para produção de aquênios (Tabela 14) e concordante com o esperado. Assim como em outras culturas, há uma forte interação do florescimento com a disponibilidade de água. O estresse hídrico reduz a expansão celular, a extrusão das anteras, a deiscência do pólen, a extensão do estigma assim como sua receptividade, e portanto contribuindo para a infertilidade (Connor \& Hall, 1997), e conseqüente queda na produção.

Unger (1990) cita que a redução do número, tamanho e peso de aquênios por capítulos e concentração de óleo está estreitamente relacionado ao baixo rendimento de aquênio, em função do estresse hídrico imposto às 
plantas. Sionit et al. (1973) e Talha \& Osman (1975) observaram que a redução do potencial hídrico do solo diminuiu a produção de aquênios, como reflexo do menor número de aquênios por capítulo.

Resultados semelhantes foram encontrados por Cox \& Jolliff (1986) trabalhando com girassol em condições de estresse severo, moderado e sem estresse, o qual observaram que o estresse moderado e severo reduziu 0 número de aquênios por capítulos em 22 e 52\%, respectivamente. Esta redução foi reflexo da redução da área do capítulo de 20 e 38\%, respectivamente para os mesmos tratamentos.

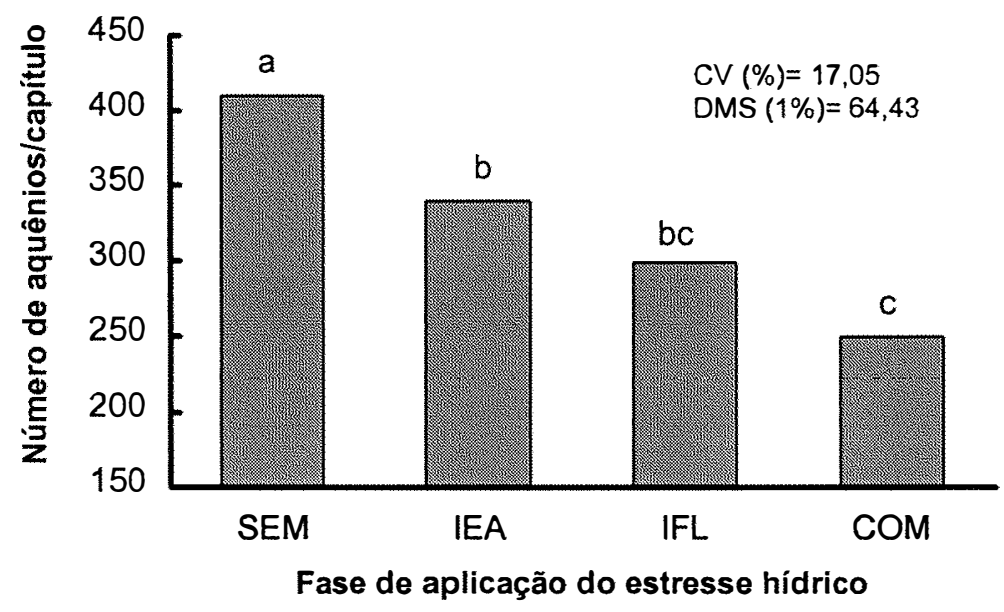

Figura 13. Número de aquênios por capítulo em função das fases de aplicação do estresse hídrico.

Na Figura 14 são apresentadas as correlação obtida entre os teores de boro nas folhas e o número de aquênios por capitulos. Na Figura 14-a estão as plantas de todos os tratamentos (SEM, IEA, IFL e COM). Observa-se que 0 coeficiente de correlação, apesar de significativo, não foi elevado, porque as plantas do tratamento COM, apesar de apresentarem maior teor de boro nas folhas, não proporcionaram o mesmo nivel de resposta direta no número de aquênios. 

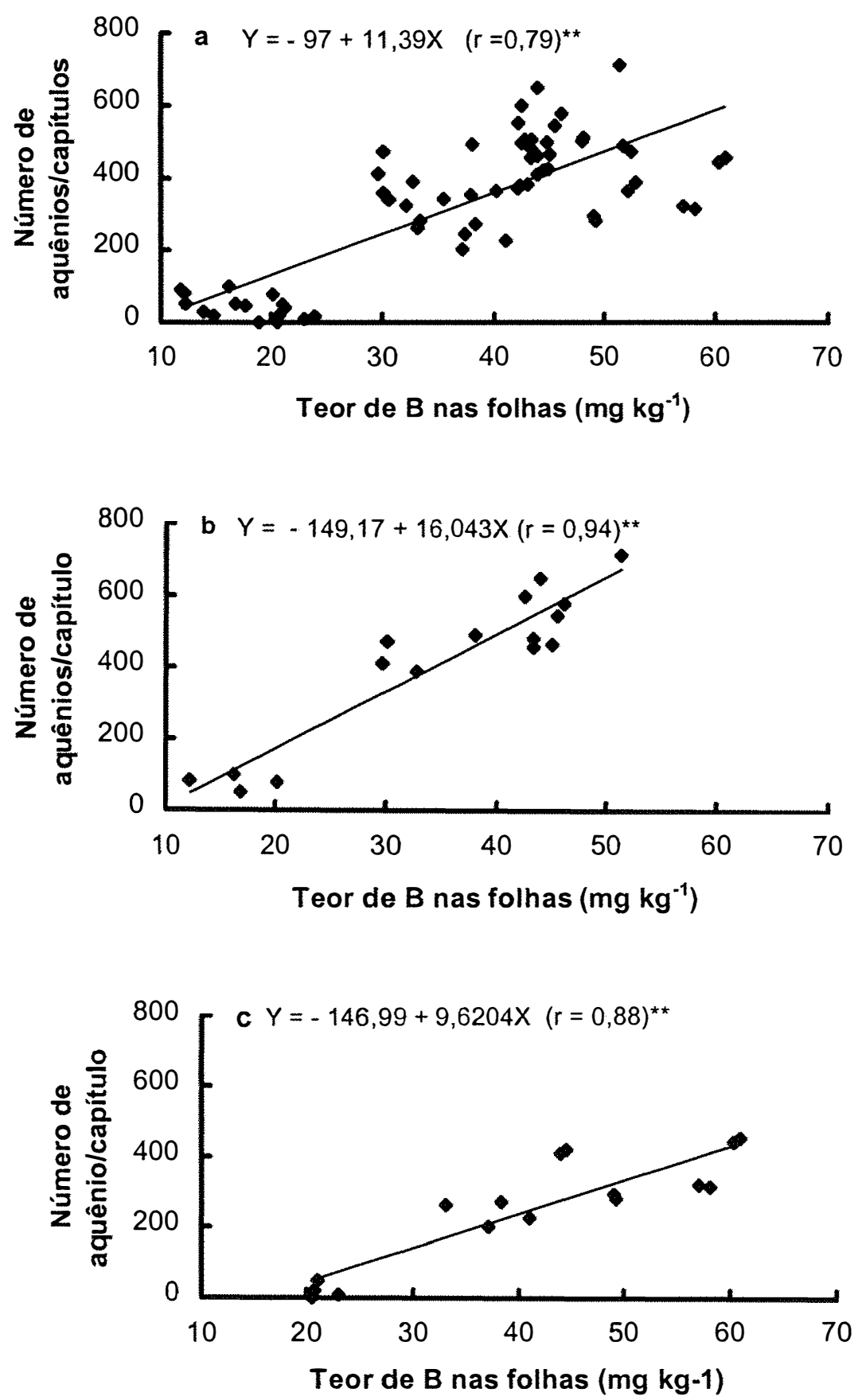

Figura 14. Correlação entre os teores de boro nas folhas e o número de aquênios no conjunto das plantas de todos os tratamentos (a), das plantas do tratamento SEM (b) e COM (c). 
Nas plantas do tratamento SEM (Figuras 14-b) o coeficiente de correlação entre os parâmetros estudados foi elevado, demonstrando que a disponibilidade hídrica foi fator determinante no número de aquênios e que, juntamente com outros parâmetros explicaria a maior produção de aquênios neste tratamento. Nas plantas do tratamento COM (Figura 14-C) apesar do coeficiente $\left(r=0,88^{* *}\right)$, a correlação entre os parâmetros estudados ocorreu com o número de aquênios significativamente menor.

\subsubsection{Peso de 1000 aquênios}

O peso de 1000 aquênios variou significativamente $(p<0,01)$ em função das fases de aplicação do estresse hídrico (Figura 15). Esta variável, juntamente com o número de aquênios, são as mais importantes na composição final da produção, refletindo as condições hídricas durante o ciclo da cultura, principalmente durante o florescimento e enchimento de aquênios.

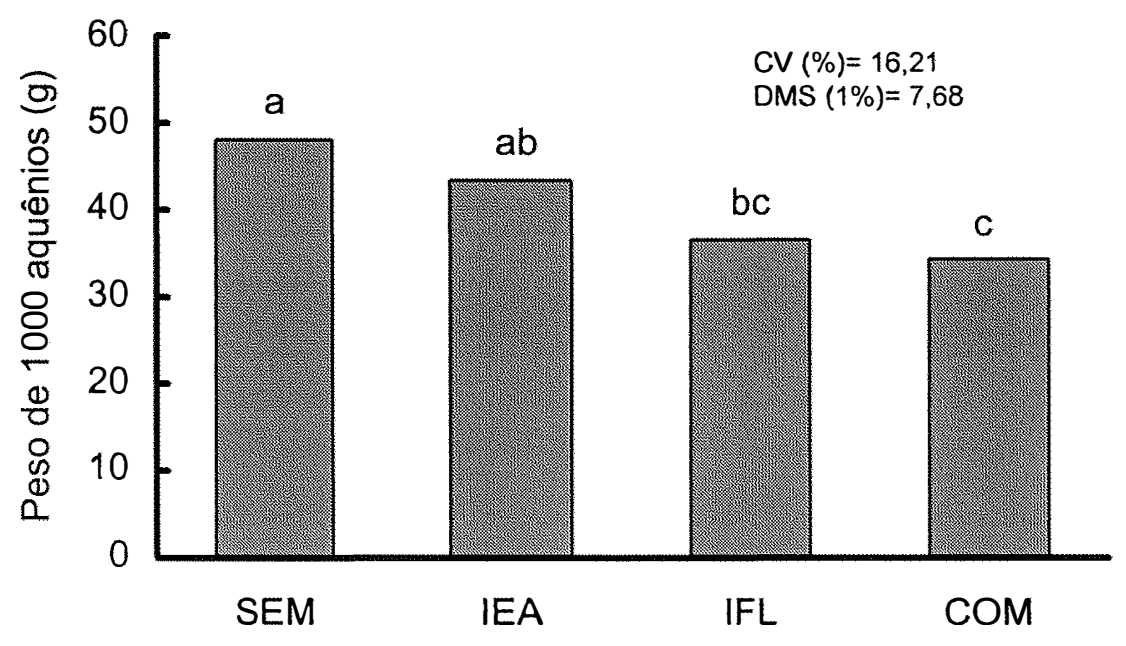

Fase de aplicação do estresse hídrico

Figura 15. Peso de 1000 aquênios em função das fases de aplicação do estresse hídrico. 
Assim como na produção e no número de aquênios por capítulo, o peso de 1000 aquênios teve um comportamento semelhante, alcançando os maiores valores nos tratamentos com maior disponibilidade hídrica. Apesar do peso de 1000 aquênios do tratamento IEA ter sido igual ao do tratamento SEM, o conjunto dessas variáveis demonstra por si só a importância da disponibilidade hídrica nas diferentes fases de desenvolvimento do girassol. Sendo assim, verifica-se que o principal parâmetro afetando a produção de aquênios no tratamento IEA foi o número de aquênios por capítulo.

O peso de 1000 aquênios por capítulo variou significativamente $(p<0,01)$ em função das doses de boro aplicadas no solo. O modelo quadrático de regressão ajustando-se ao valores obtidos (Figura 16).

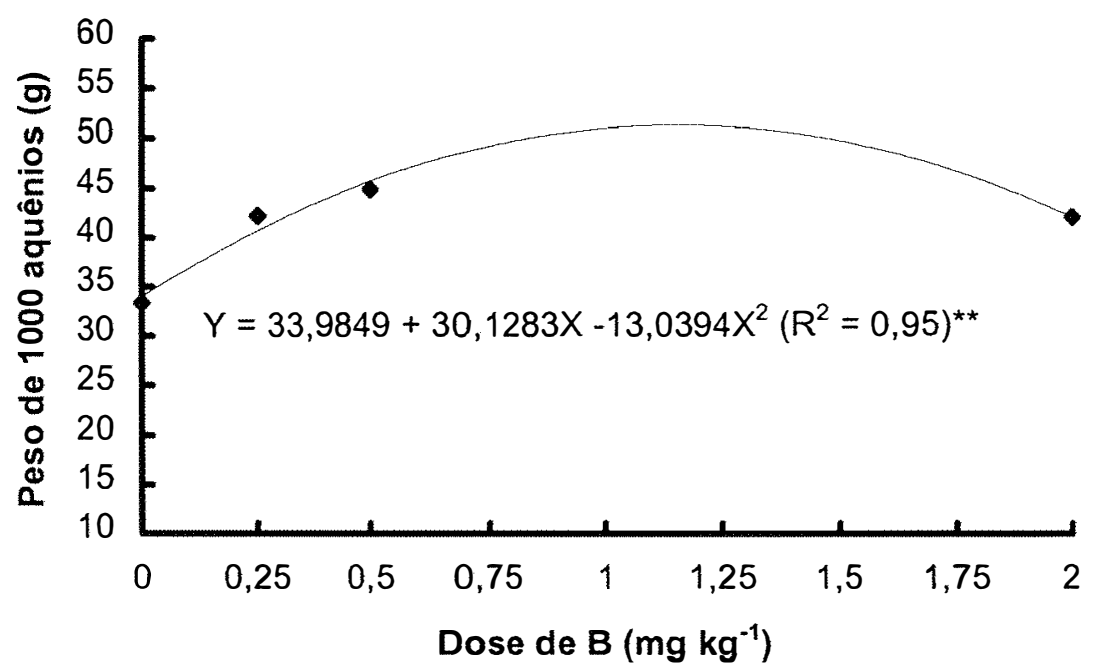

Figura 16. Peso de 1000 aquênios por capítulo em função das doses de boro aplicadas no solo.

O peso médio de 1000 aquênios de $46 \mathrm{~g}$, correspondente a $90 \%$ do peso máximo de 1000 aquênios, ou de $48 \mathrm{~g}$ para as plantas do tratamento SEM 
é inferior aqueles encontrados na literatura para este híbrido, com peso médio em torno de $60 \mathrm{~g}$, cultivado em áreas experimentais a campo.

Na Figura 17 são apresentadas as correlação obtidas entre o peso de 1000 aquênios e a produção de aquênios. Na Figura 17-a estão contidas as plantas de todos os tratamento (SEM, IEA, IFL e COM) e nas Figuras 17-b, c e d as plantas dos tratamentos SEM, IFL e IEA, respectivamente.
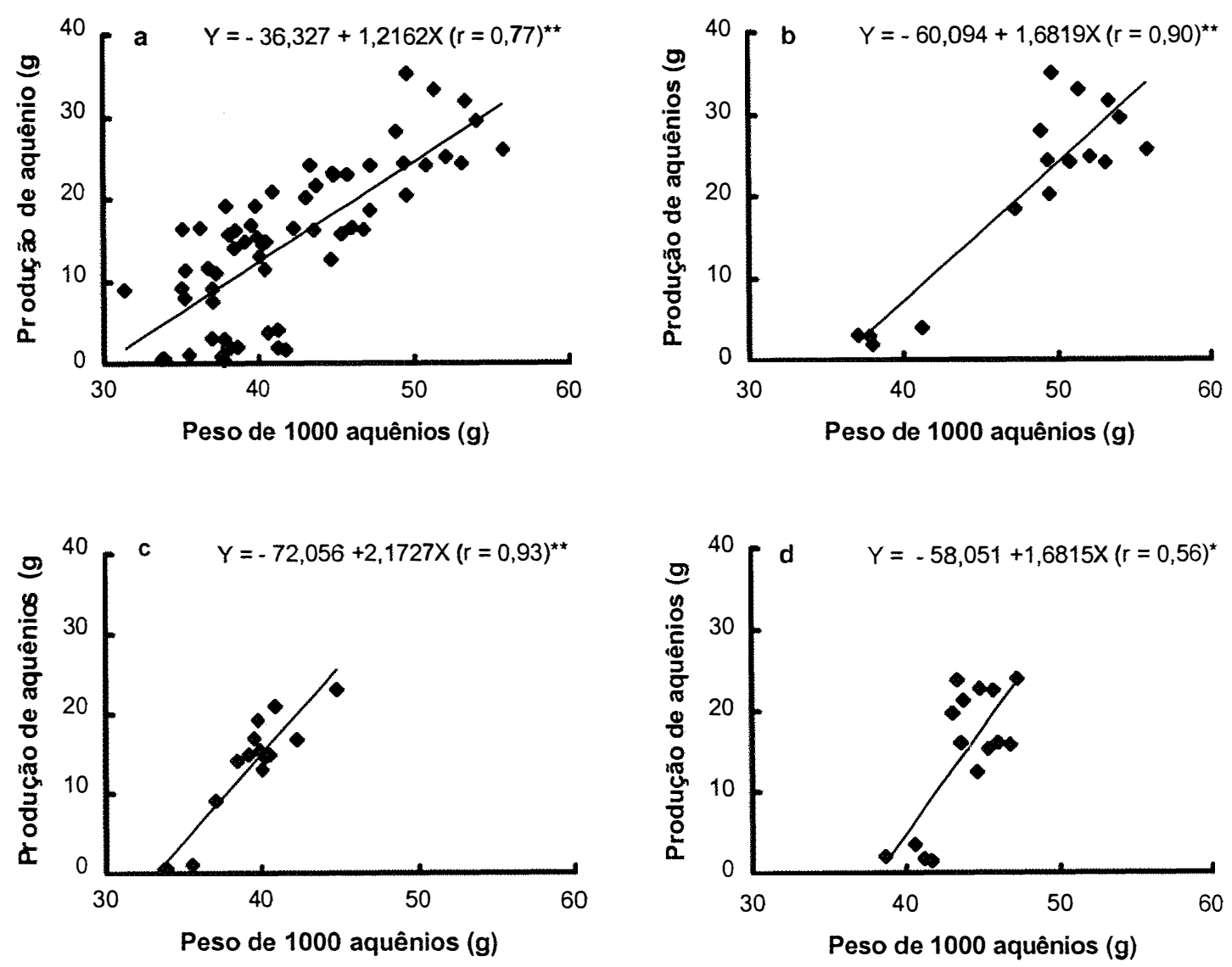

Figura 17. Correlação entre o peso de 1000 aquênios e a produção de aquênios das plantas de todas as fases (a) e das plantas das fases SEM (b), IFL (c) e IEA (d).

A análise separada do coeficiente de correlação da Figura 17-a não permite avaliar corretamente a importância do peso de aquênio na composição 
da produção final, porque nas plantas do tratamento COM não houve correlação dos parâmetros avaliados.

Nas plantas do tratamento SEM, o coeficiente de correlação foi elevado em função da alta produção e peso de 1000 aquênios. Nas plantas do tratamento IFL a correlação foi ligeiramente superior, porém em níveis de produção e peso de 1000 aquênios, significativamente inferior (Figura 17-c). 0 coeficiente das plantas do tratamento IEA foi de $0,56^{\star}$ em função de que a baixa produção de aquênios não estava associada ao baixo peso de 1000 aquênios, conforme pode ser observado na Figura 15 e Tabela 14.

\subsubsection{Teor de óleo nos aquênios}

O teor de óleo nos aquênios variou significativamente $(p<0,01)$, em função das doses de boro aplicadas no solo (Figura 18). O modelo quadrático de regressão ajustou-se aos teores obtidos.

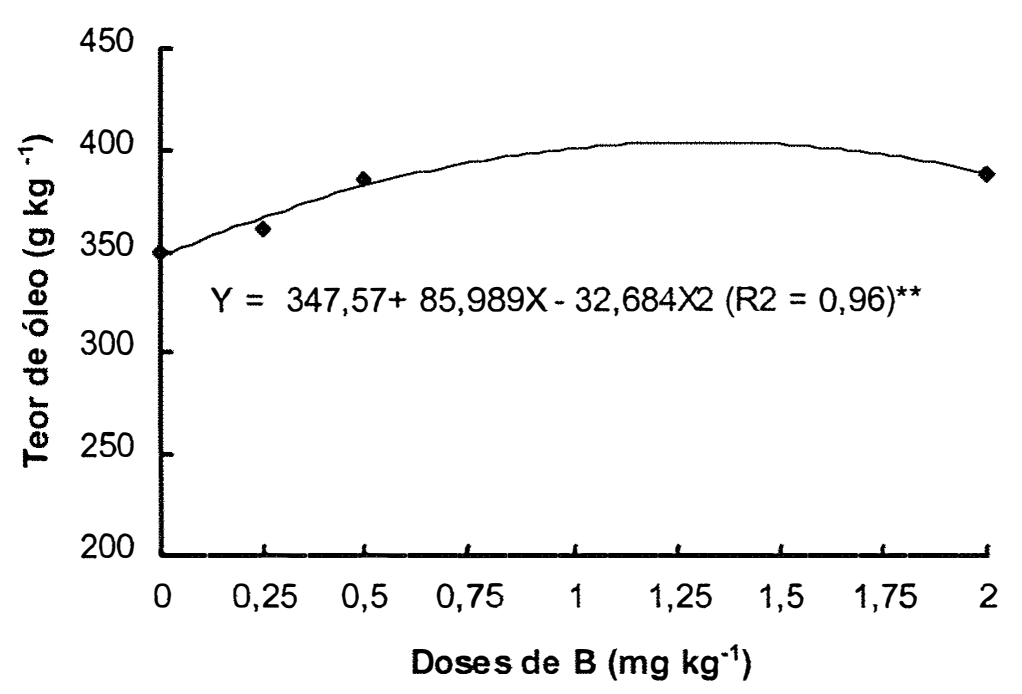

Figura 18. Teor de óleo dos aquênios em função das doses de boro aplicadas no solo. 
Na dose de $0,2 \mathrm{mg} \mathrm{kg}^{-1}$ de boro aplicada no solo foi obtida a produção correspondente a $90 \%$ do teor máximo de óleo $\left(364 \mathrm{~g} \mathrm{~kg}^{-1}\right)$. Em condições experimentais a campo, este híbrido alcança teores médios de óleo nos aquênios, em torno de $450 \mathrm{~g} \mathrm{~kg}^{-1}$. As diferenças se devem às condições distintas de condução dos trabalhos.

Na Figura 19 são apresentados os resultados do teor de óleo nos aquênios $(p<0,05)$ em função das fases de aplicação do estresse hídrico. $O$ tratamento IFL atingiu teor de óleo de $407 \mathrm{~g} \mathrm{~kg}^{-1}$, superior a todos os demais, enquanto o tratamento COM proporcionou o menor teor de óleo com $350 \mathrm{~g} \mathrm{~kg}^{-1}$.

O maior teor de óleo alcançado no tratamento IFL, foi um comportamento contrário ao descrito por Robelin (1967), que destaca a sensibilidade do girassol à seca, entre 20 dias antes e 20 dias após a floração, época em que o déficit hídrico diminui consideravelmente a produção de aquênios e o conteúdo de óleo.

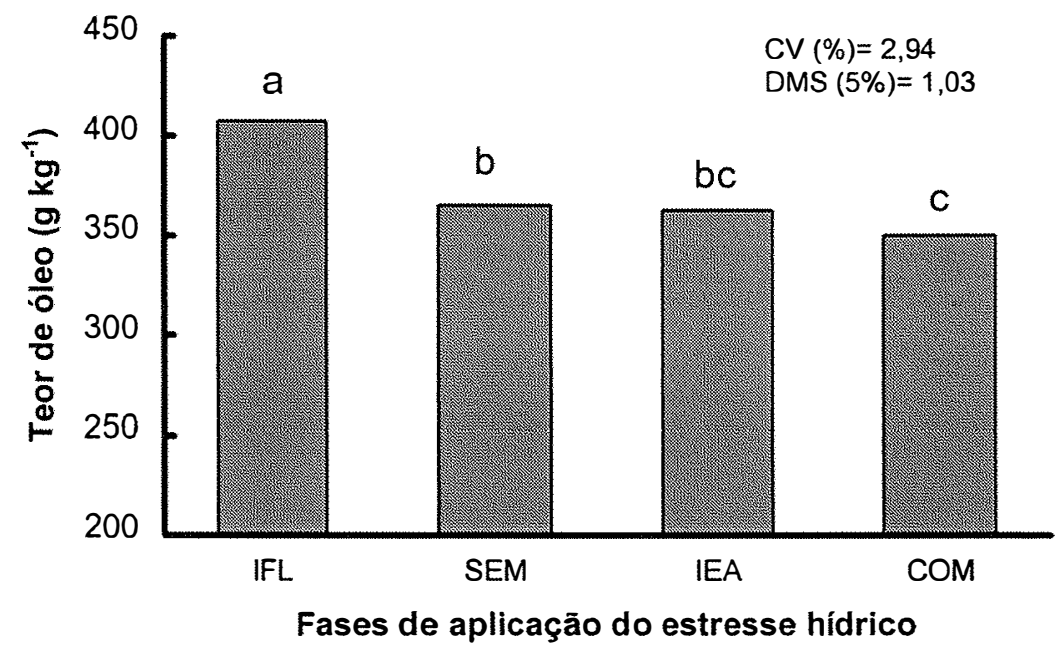

Figura 19. Teor de óleo dos aquênios em função das fases de aplicação do estresse hídrico. 
Segundo o mesmo autor, a pior influência da seca sobre o conteúdo de óleo ocorre nos primeiros 10 dias após o secamento das flores liguladas. Assim, em função do enchimento de aquênios iniciar neste período, o menor teor de óleo nos tratamentos IEA e COM, estariam de acordo com o esperado. Por outro lado, o mesmo não seria para o tratamento SEM com $365 \mathrm{~g} \mathrm{~kg}^{-1}$ de óleo, que durante todo o ciclo não foi submetido ao regime de estresse hídrico.

Não obstante, quando se analisa o rendimento de óleo (Figura 20), verifica-se que este parâmetro teve um comportamento semelhante àquele ocorrido com a produção de aquênios (Figura 10). Desta forma percebe-se que o fator mais importante para a rendimento de óleo foi, além do seu teor inerente, fundamentalmente a produção de aquênios.

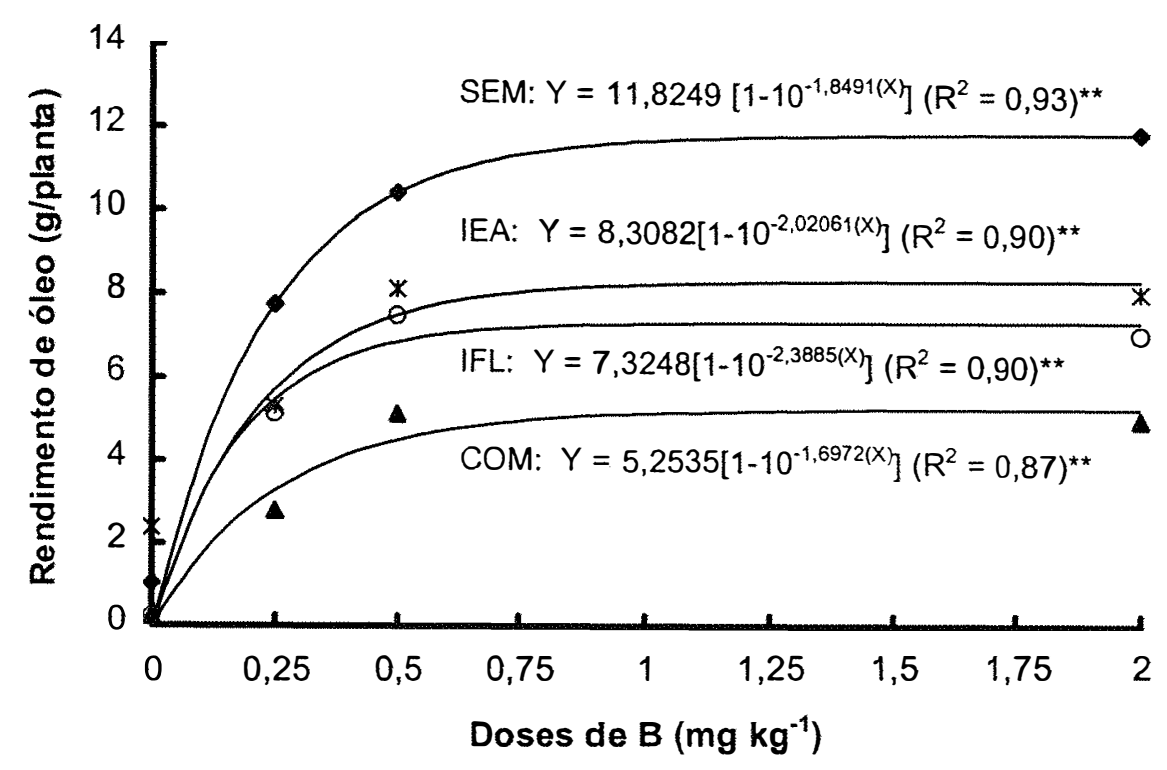

Figura 20. Rendimento de óleo em função das doses de boro e fases de aplicação do estresse hídrico.

A comparação entre os resultados apresentados nas Figuras 19 e 20 evidenciam que apesar do tratamento SEM ter apresentado menor teor de óleo que o tratamento IFL, atingiu o maior rendimento de óleo. Este resultado foi 
obtido em função da maior produção de aquênios tratamento SEM em comparação ao tratamento IFL. O rendimento de óleo por capítulo do tratamento SEM foi $61 \%$ superior ao do IFL, tomando-se por base $90 \%$ do rendimento máximo, correspondente a um aumento de $4,0 \mathrm{~g}$ de óleo por capítulo. Isto demonstra a importância da disponibilidade hídrica em períodos críticos de desenvolvimento da cultura.

Assim como nas equações de Mitscherlich da Figura 10, observa-se que o termo b da equação, o qual representa o teor do nutriente disponível no solo para atender as necessidades metabólicas das plantas, é nulo para a variável em estudo. Esta constatação demonstra que apesar da existência de boro no solo, este teor, independente da disponibilidade hídrica, não seria suficiente para o rendimento de óleo, que é função direta da produção e do teor de óleo nos aquênios, sem a adição de fonte externa do nutriente. Assim como na Figura 10 o coeficiente de eficácia (c) do tratamento COM foi inferior a todos os demais, enquanto para as plantas do tratamento IFL obteve-se o maior coeficiente com 2,39 $\mathrm{kg}$ de solo por $\mathrm{mg}^{-1}$ de B.

\subsection{Nutrientes}

\subsubsection{Teor de boro nas folhas}

A análise de variância revelou significância $(p<0,01)$ para o teor de boro nas folhas de girassol em função das doses de boro aplicadas no solo e nas fases de aplicação do estresse hídrico. A interação doses de boro no solo versus estresse hídrico também foi significativa para o teor de boro nas folhas, nos tratamentos SEM e COM (Figura 21) ajustando-se equações de Mitscherlich aos teores de $B$ nas folhas. O teor do nutriente aumentou até a dose máxima de boro aplicada ao solo, alcançando 47,86 e $59,17 \mathrm{mg} \mathrm{kg}^{-1}$ de B nos tratamentos SEM e COM, respectivamente. 


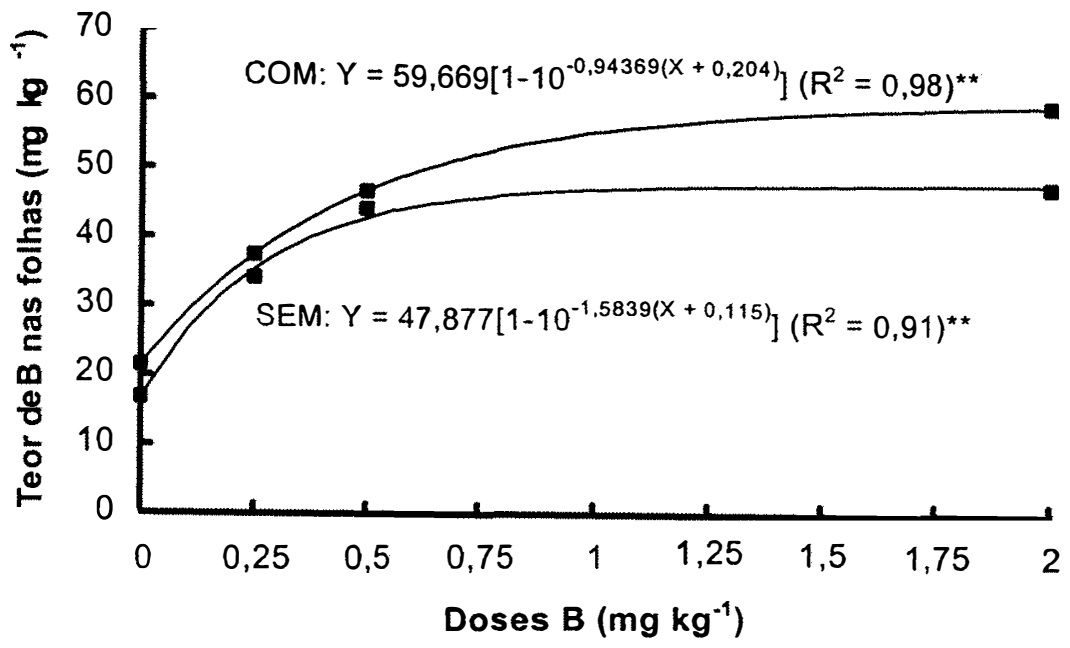

Figura 21. Teor de boro nas folhas de girassol, no início do florescimento, em função das doses de boro aplicadas no solo e fases de aplicação do estresse hídrico.

Com base nas equações, observa-se que a obtenção de $90 \%$ do teor máximo de boro nas folhas nos tratamentos SEM $\left(43,07 \mathrm{mg} \mathrm{kg}^{-1}\right.$ de B) e COM $\left(53,25 \mathrm{mg} \mathrm{kg}^{-1}\right.$ de B) foi conseguida com a aplicação de 0,51 e 0,82 $\mathrm{mg} \mathrm{kg}^{-1} \mathrm{de}$ B no solo, respectivamente.

Na Figura 10, verifica-se que a estimativa de $90 \%$ da produção máxima de aquênios das plantas do tratamento SEM, tomado como padrão de desenvolvimento, foi obtida com a dose de $0,46 \mathrm{mg} \mathrm{kg}^{-1}$ de boro aplicada no solo. Aplicando-se esta dose na equação representativa do teor de boro nas folhas das plantas no tratamento SEM (Figura 21), obtém-se o teor de $42 \mathrm{mg}$ $\mathrm{kg}^{-1}$ de $\mathrm{B}$ nas folhas. Portanto, os teores de boro nas folhas de 42,00 e 43,07 $\mathrm{mg} \mathrm{kg}^{-1}$, correspondentes a $90 \%$ da produção máxima de aquênios e do teor de boro nas folhas, respectivamente, seriam considerados adequados para a cultura do girassol. 
Reuter et al. (1997) trabalhando em campo, estabeleceram teores de boro de 40 a $250 \mathrm{mg} \mathrm{kg}^{-1}$ como adequados em folhas de girassol, nos estádios $R_{4}$ e $R_{5}$, descritos por Schneiter \& Miller (1981). Sfredo \& Sarruge (1990), também a campo, determinaram no início do florescimento, o intervalo de 88 a $102 \mathrm{mg} \mathrm{kg}^{-1}$ de B, como adequado para a cultura do girassol. Teores menores foram encontrados por Blamey et al. (1979), que estabeleceram a concentração crítica de boro na folha mais jovem fisiologicamente madura, no florescimento, a campo e Baumgartner et al. (1986) na parte aérea de plantas de girassol colhido aos 60 dias após a emergência das plantas (início da formação do capítulo), em casa de vegetação, como sendo 34 e $28 \mathrm{mg} \mathrm{kg}^{-1}$ de B, respectivamente.

Na Figura 22 são apresentadas as correlações obtidas entre o teor de boro nas folhas e a produção de aquênios. Nas plantas dos tratamentos SEM, IEA, IFL e COM (Figura 22a) verifica-se que o coeficiente de correlação, apesar de significativo, não foi elevado, em função de que nas plantas dos tratamentos COM, IFL e IEA, a produção de aquênios foi significativamente menor.

Quando se avalia separadamente as plantas do tratamento SEM (Figura 22b) e COM (Figura 22c), observa-se melhor correlação entre os parâmetros estudados. Nas plantas do tratamento SEM, a elevada correlação demonstra que a disponibilidade hídrica durante todo o ciclo foi o fator determinante na produção de aquênios. Nas plantas do tratamento COM, apesar do coeficiente de $0,89^{* *}$ entre os parâmetros estudados, a correlação ocorreu com uma produção de aquênios significativamente menor em relação aos demais tratamentos. 

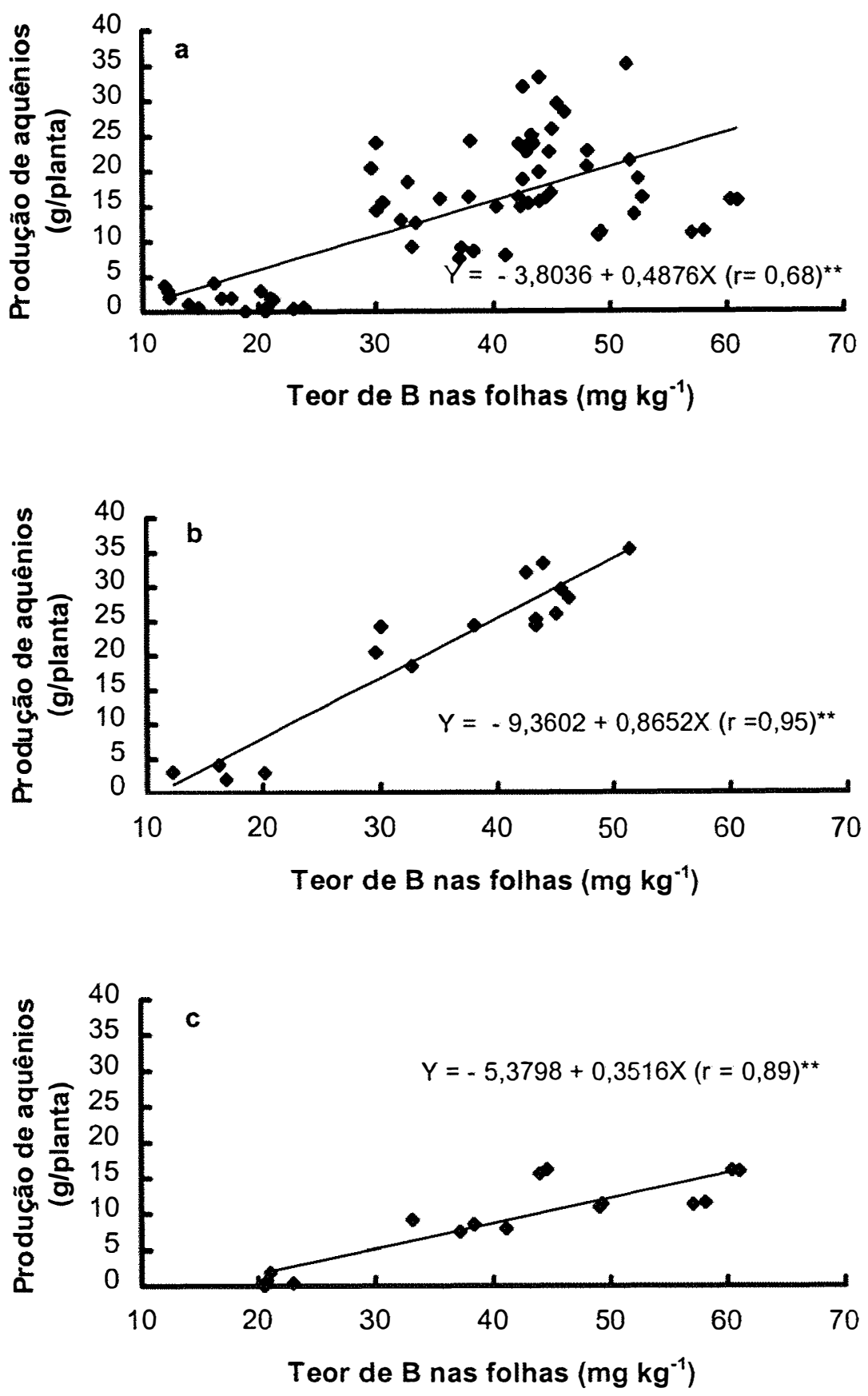

Figura 22. Correlação entre o teor de boro nas folhas de girassol e produção de aquênios no conjunto de todos os tratamentos (a), das plantas do tratamento SEM (b) e COM (c). 
Na Figura 23 observa-se que o tratamento COM alcançou valor médio de boro nas folhas de $41,2 \mathrm{mg} \mathrm{kg}^{-1}$ e foi significativamente superior ao dos tratamentos sem estresse até o início do florescimento (SEM), com teor médio de $35,6 \mathrm{mg} \mathrm{kg}^{-1}$ de $B$.

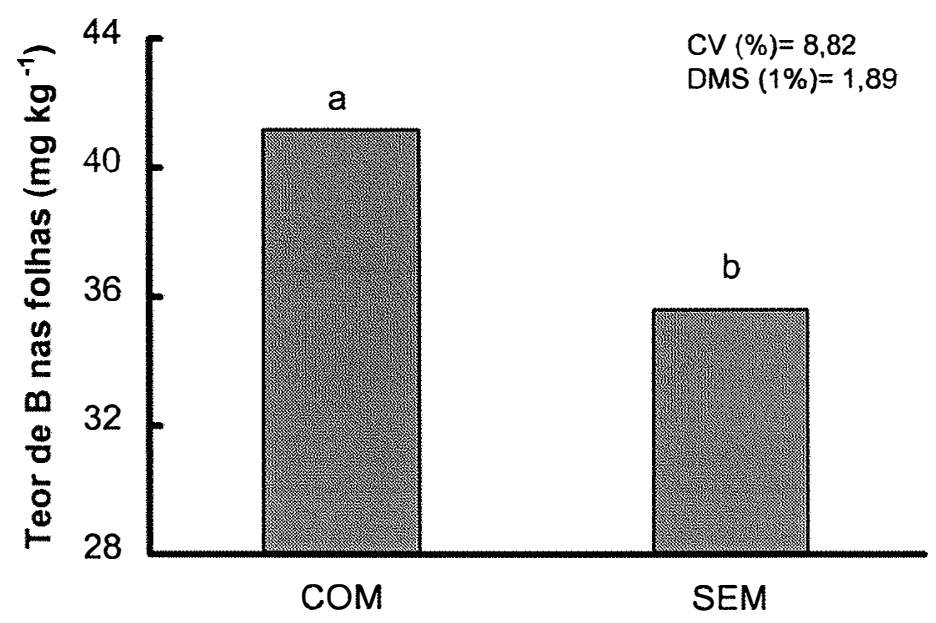

Fases de aplicação do estresse hidrico

Figura 23. Teor de boro nas folhas de girassol, no início do florescimento nas fases de aplicação do estresse hídrico.

Apesar das plantas do tratamento COM apresentarem maior teor de boro nas folhas, foi aquele com menor produção de matéria seca total e de grãos, Figuras 4 e 12, respectivamente. Esta constatação mostra que o estado hídrico do solo foi o fator determinante no desenvolvimento do girassol, já que no tratamento SEM, com $35,6 \mathrm{mg} \mathrm{kg}^{-1}$ de $B$ nas folhas, provavelmente em função do efeito de diluição, possibilitou alcançar os maiores parâmetros de desenvolvimento e produção da cultura. Constata-se também que, não obstante o maior teor de boro na folhas do tratamento COM (Figura 23), foi aquele que, de modo geral, apresentou o menor conteúdo do nutriente nas 
plantas, conforme pode ser constatado na Tabela 15. No Apêndice 4 são apresentados os teores de boro nas folhas.

Tabela 15. Conteúdo total de boro em plantas de girassol em resposta às doses de B aplicadas no solo.

\begin{tabular}{ccccccc}
\hline $\begin{array}{c}\text { Dose de B } \\
\left(\mathrm{mg} \mathrm{kg}^{-1}\right)\end{array}$ & SEM & IEA & IFL & COM & $\begin{array}{c}\text { D.M.S } \\
\text { CV }\end{array}$ & $\begin{array}{c}\text { CV } \\
(\%)\end{array}$ \\
\hline 0,00 & $1,036 \mathrm{a}$ & $0,956 \mathrm{a}$ & $0,857 \mathrm{a}$ & $0,538 \mathrm{a}$ & 0,62 & 26,73 \\
0,25 & $2,383 \mathrm{a}$ & $2,234 \mathrm{a}$ & $1,818 \mathrm{a}$ & $1,079 \mathrm{~b}$ & 0,60 & 10,80 \\
0,50 & $3,297 \mathrm{a}$ & $3,030 \mathrm{ab}$ & $2,476 \mathrm{~b}$ & $1,484 \mathrm{c}$ & 0,65 & 8,52 \\
2,00 & $3,426 \mathrm{a}$ & $2,952 \mathrm{ab}$ & $2,728 \mathrm{~b}$ & $2,031 \mathrm{c}$ & 0,65 & 7,37 \\
\hline
\end{tabular}

Média seguidas pelas mesmas letras na linha não diferem entre sí pelo teste de Tukey, ao nível de $1 \%$ de probabilidade.

Os primeiros sintomas de deficiência de boro nas plantas foram observados nos tratamentos sem estresse, aos 45 dias após a emergência das plantas, inicialmente nas doses 0,0 de $B$, em função do maior desenvolvimento destas plantas em comparação com as sob condições de estresse hídrico permanente, caracterizados por manchas marrons no caule, logo abaixo dos pecíolos das folhas próximas ao botão floral, seguido de deformação e espessamento das mesmas .

Aos 57 dias após a emergência das plantas, na mesma dose de boro, nos tratamentos sem estresse hídrico, apresentavam sintomas mais severos da deficiência de nutriente e em maior distribuição na planta em função do desenvolvimento das mesmas. Entretanto, nas plantas do tratamento COM, até esta data, as mesmas não mostravam sintomas da deficiência do nutriente. Esta constatação pode ser entendida observando-se a Figura 21, que destaca o maior teor de boro nas folhas alcançado pelo tratamento COM, bem como pela menor demanda de boro para o desenvolvimento normal do girassol.

$\mathrm{Na}$ mesma época, na dose de $0,25 \mathrm{mg} \mathrm{kg}^{-1}$ de $\mathrm{B}$, os tratamentos sem estresse hídrico, em função do maior desenvolvimento das plantas e 
necessidades nutricionais, apresentavam leves sintomas da deficiência de boro. Nas plantas do tratamento COM, com a mesma dose de B, as plantas não mostravam sintoma da deficiência do nutriente, provavelmente em função do pequeno desenvolvimento das plantas.

Como ilustração da correspondência entre o teor de boro no solo e nas folhas das plantas do tratamentos SEM, verifica-se que na dose $0,25 \mathrm{mg} \mathrm{kg}^{-1}$ de $B$ aplicado no solo, o teor do elemento nas folhas estava em torno de 35,2 $\mathrm{mg}$ $\mathrm{kg}^{-1}$ de $\mathrm{B}$. Estes teores seriam desta forma enquadrado como marginal para Blamey et al. (1979) e (1981) e crítica (deficiente) para Blamey et al. (1997). Portanto, concordando com as observação dos sintomas de deficiência de boro nas folhas do girassol deste tratamento.

Nas doses de 0,5 e 2,0 mg kg-1 de boro aplicado no solo, independente da fase de aplicação do estresse hídrico, as plantas não apresentaram sintomas aparentes de deficiência de boro.

Nas Figuras 24 e 25 são apresentadas seqüências de sintomas típicos de deficiência de boro em folhas, caule e capítulos da plantas de girassol.

\section{2.2 Teor de nitrogênio nas folhas}

O resultado da análise de variância do teor de nitrogênio nas folhas do girassol, em função das fases de aplicação do estresse hídrico, revelou significância $(p<0,01)$, conforme demonstrado na Figura 26 . Igualmente ao teor de boro nas folhas, as plantas cultivadas durante todo o ciclo sob condições de restrição hídrica apresentaram maiores teores de $\mathrm{N}$ que aquelas sem estresse hídrico durante ciclo. 


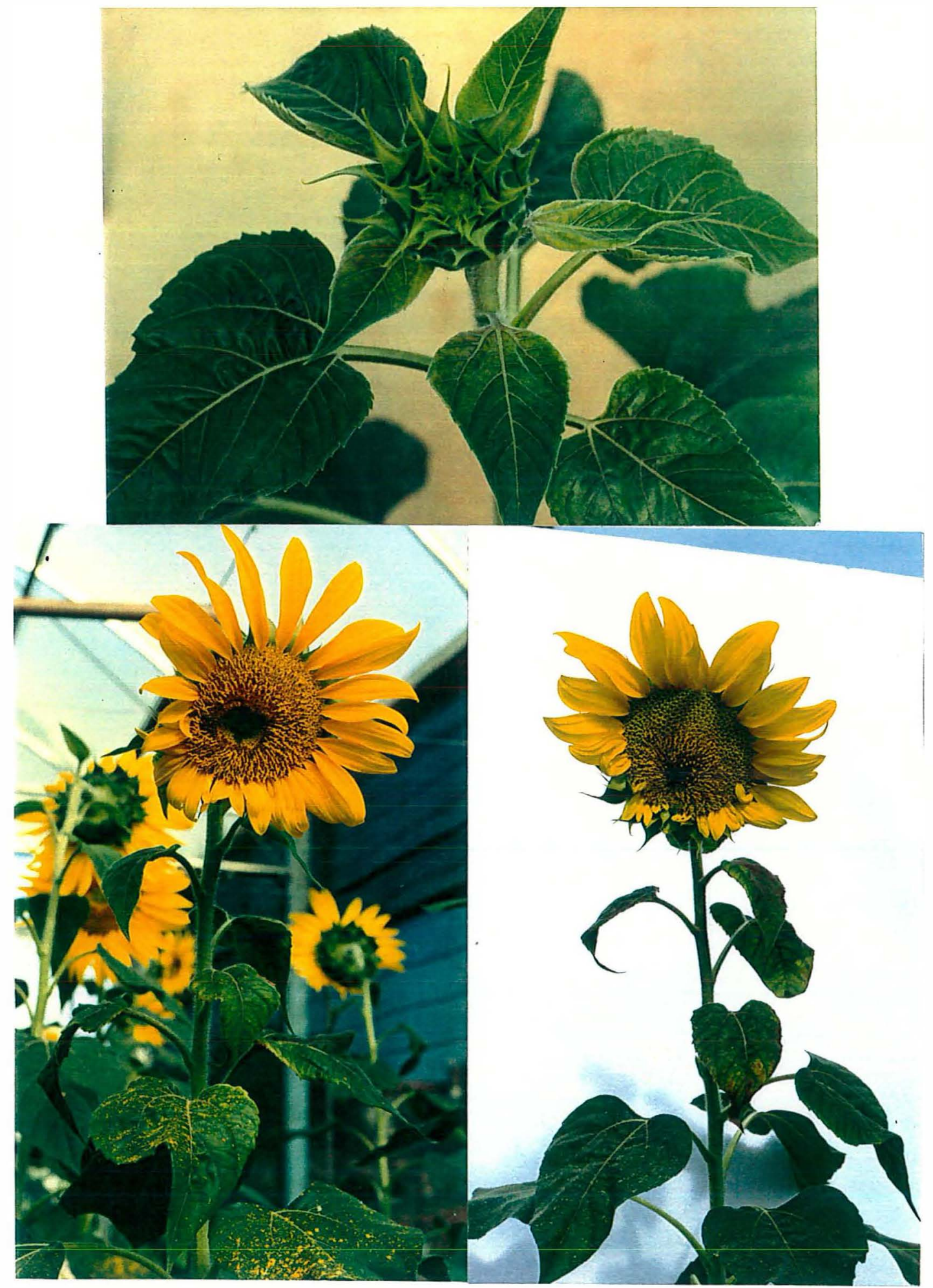

Figura 24. Sintomas de deficiência de boro em folhas, pecíolos, caule e capítulos de girassol. 


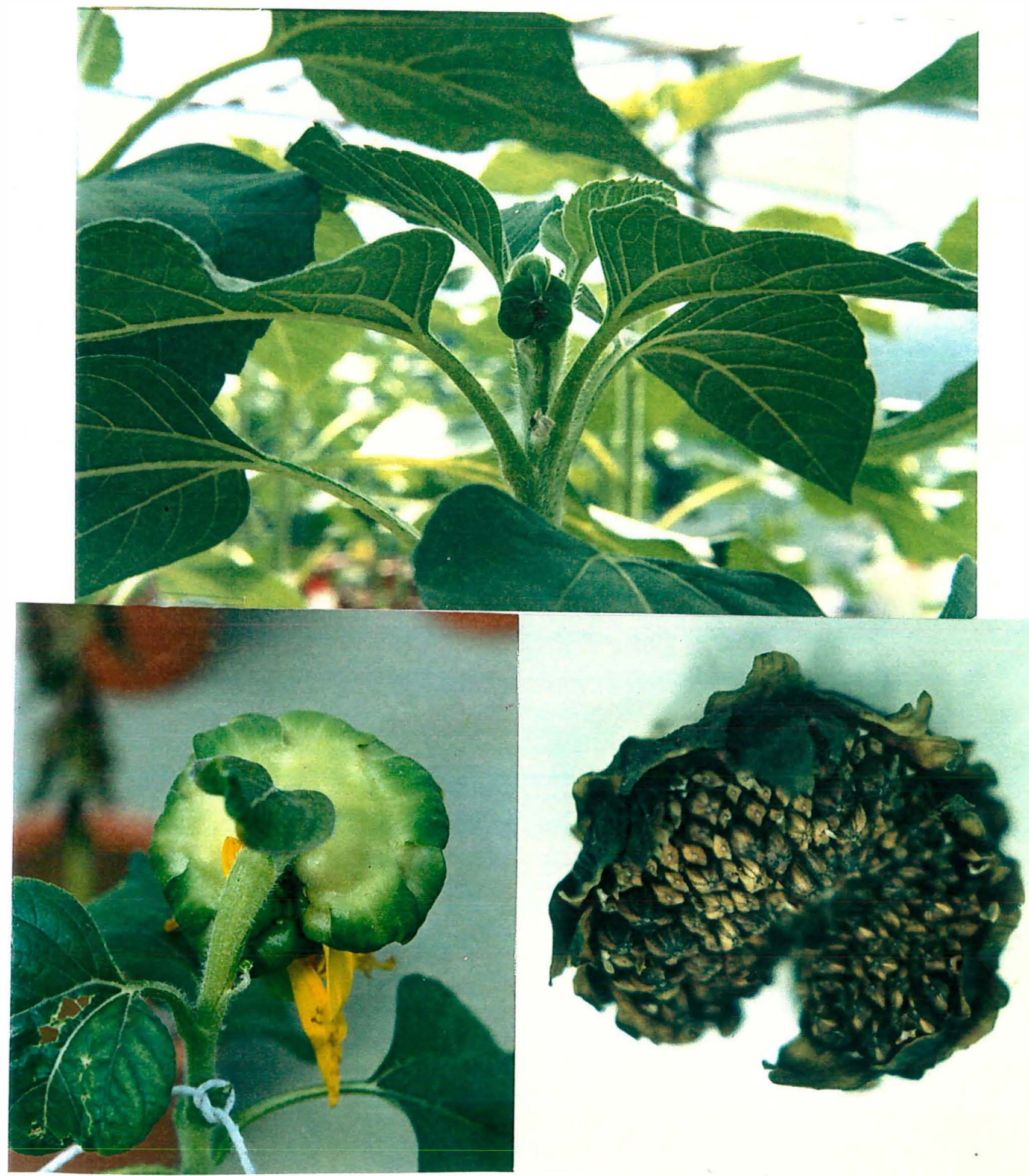

Figura 25. Sintomas de deficiência de boro em capítulos de girassol. 


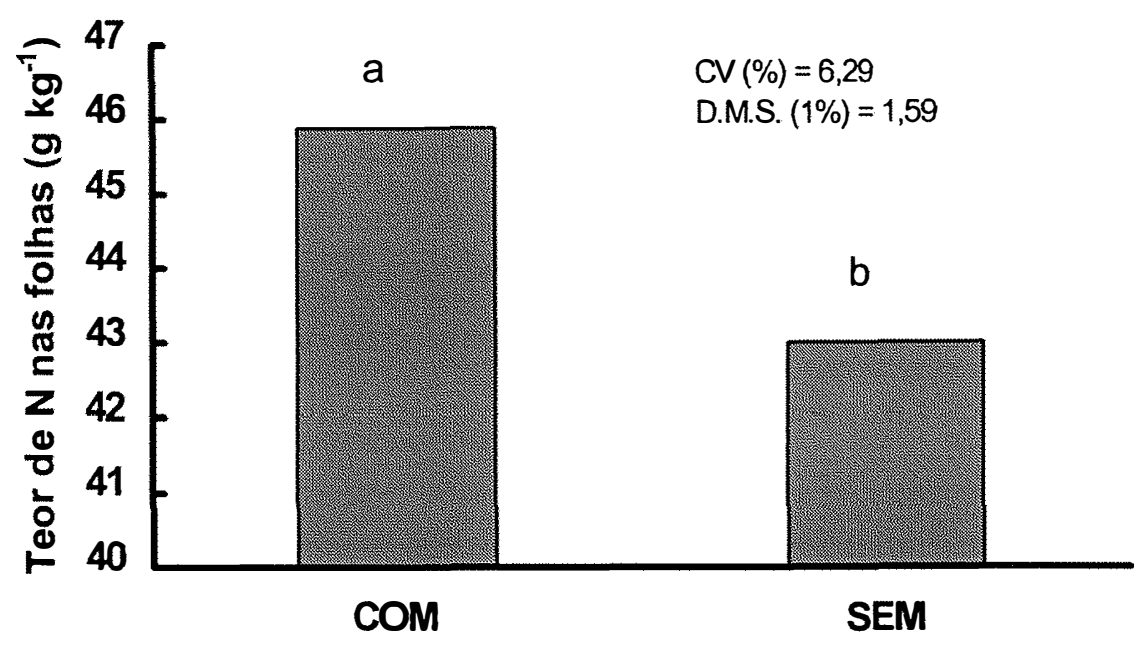

Fases de aplicação do estresse hídrico

Figura 26. Teor de nitrogênio nas folhas de girassol, no início do florescimento, nas fases de aplicação do estresse hídrico.

Apesar das diferenças entre os tratamentos, os teores de 45,9 e 43,0 g $\mathrm{kg}^{-1}$ de $\mathrm{N}$ nas folhas, nos tratamentos COM e SEM, respectivamente, ambos são considerados adequados para Reuter at al, (1997). Bergmann (1992), considera adequado teores de nitrogênio nas folhas, colhido no estádio $R_{5.1}$ entre $30-50 \mathrm{~g} \mathrm{~kg}^{-1}$ de $\mathrm{N}$. Sfredo et al. (1983) citam que o teor de $36,0 \mathrm{~g} \mathrm{~kg}^{-1} \mathrm{~N}$, das folhas da planta inteira, colhidas no início do florescimento, como adequada para o girassol. O maior teor de $\mathrm{N}$ nas folhas no tratamento COM, foi devido ao efeito de concentração do nutriente nos tecidos, em função do menor desenvolvimento dessas plantas, podendo ser melhor constatado avaliando-se o teor nas folhas (Figura 26) e o conteúdo total nas plantas do girassol, na Tabela 16. No apêndice 3 são apresentados os teores de nitrogênio nas folhas de girassol. 
Tabela 16. Conteúdo de nitrogênio em plantas de girassol em resposta às doses de B aplicadas no solo.

\begin{tabular}{ccccccc}
\hline Dose de B & SEM & IEA & IFL & COM & D.M.S & CV \\
$\left(\mathrm{mg} \mathrm{kg}^{-1}\right)$ & - & & & & & \\
0,00 & $2,52 \mathrm{a}$ & $2,59 \mathrm{a}$ & $2,02 \mathrm{~b}$ & $1,20 \mathrm{c}$ & 0,47 & 10,31 \\
0,25 & $3,18 \mathrm{a}$ & $2,97 \mathrm{ab}$ & $2,19 \mathrm{~b}$ & $1,29 \mathrm{c}$ & 0,80 & 11,14 \\
0,50 & $3,22 \mathrm{a}$ & $3,01 \mathrm{ab}$ & $2,45 \mathrm{~b}$ & $1,37 \mathrm{c}$ & 0,64 & 8,55 \\
2,00 & $3,12 \mathrm{a}$ & $2,89 \mathrm{a}$ & $2,28 \mathrm{~b}$ & $1,65 \mathrm{c}$ & 0,46 & 6,25 \\
\hline \hline
\end{tabular}

Média seguidas pelas mesmas letras na linha não diferem entre si pelo teste de Tukey, ao nivel de $1 \%$ de probabilidade.

Ao contrário do que encontraram Kastori \& Petrovic (1989), tanto nos tratamentos sem aplicação de boro, quando há carência e menor desenvolvimento das plantas, ou na dose de $2,0 \mathrm{mg} \mathrm{kg}^{-1}$ do elemento, quando já havia alcançado o patamar máximo de produção de aquênios (Figura 10), as doses de boro aplicadas no solo não reduziram os teores de nitrogênio nas folhas, como poderia ser esperado, em função do efeito de inibição não competitiva entre o boro $\left(\mathrm{H}_{2} \mathrm{BO}_{3}{ }^{-}\right)$e nitrogênio $\left(\mathrm{NO}_{3}{ }^{-}, \mathrm{NH}_{4}{ }^{+}\right)$, conforme citado por Malavolta et al. (1997). Segundo Oertli \& Grgurevic (1975), em pH 7 o teor de $\mathrm{H}_{2} \mathrm{BO}_{3}^{-}$na solução do solo é menor que $1 \%$. Sendo assim, no pH do solo em que foi cultivado o girassol, em torno de 5,5, essa espécie não estaria em concentração suficiente para ocasionar inibição não competitiva com o N, e desta forma, afetar a absorção do nitrogênio.

$\mathrm{Na}$ análise de tecido das plantas colhida aos 89 dias após a emergência, estádio $R_{7}-R_{8}$, as plantas do tratamentos SEM, IEA e IFL, apresentam tendência de redução dos teores de nitrogênio em função do aumento das doses de boro aplicadas no solo (Tabela 17). Enquanto na dose 0,0 de B, o teor médio de $\mathrm{N}$ nos três tratamento foi de $39,8 \mathrm{~g} \mathrm{~kg}^{-1}$ de $\mathrm{N}$ na maior dose de $\mathrm{B}$ e alcançou somente $32,2 \mathrm{~g} \mathrm{~kg}^{-1}$ de $\mathrm{N}$. Esta tendência observada aos 89 dias de 
desenvolvimento estaria, a princípio, concordante com os dados encontrados por Kastori \& Petrovic (1989). Apesar da redução no teor de $\mathrm{N}$ nas folhas na dose de $2,0 \mathrm{mg} \mathrm{kg}^{-1}$ de $B$ aplicado no solo, provavelmente não tenha afetado ou reduzido a produção de aquênios, pois ainda seria considerado adequado, para o desenvolvimento normal do girassol (Bergmann, 1992).

Neste estádio de desenvolvimento das plantas, o sistema radicular do girassol ainda permanece capaz de absorver o nitrogênio disponivel do solo, o qual é dependente entre outros fatores do nível do nutriente no solo (Connor \& Sadras, 1992). Neste período também é de grande importância no suprimento de $\mathrm{N}$ para os aquênios, a redistribuição do nutriente contido nas folhas e, a combinação de ambas as fontes de nitrogênio, solo e folhas, possibilita o maior rendimento (Steer et al., 1985). Portanto, a redução nos teores de $\mathrm{N}$ das folhas colhidas aos 89 dias (Apêndice 3) em comparação com os teores alcançados no início do florescimento (Apêndice 3 ) pode ser explicada pela remobilização de parte do $\mathrm{N}$ contido na parte aérea das plantas, para os capítulos e para os aquênios, o que estaria de acordo com as observações de Vranceanu (1977), Cheng \& Zubriski (1978) e Hocking \& Steer (1983). Gachon (1972), também estudando a absorção de nitrogênio pelos diferentes órgãos e fases de desenvolvimento do girassol, observou uma intensa translocação do elemento das folhas e talos para os capítulos e, sobretudo para ao aquênios, após a floração.

Nas plantas colhida aos 89 dias observa-se que apesar dos teores de $\mathrm{N}$ mais elevado no tratamento COM (Apêndice 3), apresentou conteúdo de nitrogênio nas folhas inferior aos demais (Tabela 17). 
Tabela 17. Conteúdo total de nitrogênio em plantas de girassol em resposta às doses de B aplicadas no solo, aos 89 dias após a emergência.

\begin{tabular}{ccccc}
\hline $\begin{array}{c}\text { Dose de } \mathrm{B} \\
\left(\mathrm{mg} \mathrm{kg}^{-1}\right)\end{array}$ & SEM & IEA & IFL & COM \\
\hline 0,00 & 2,01 & 1,74 & 1,87 & 0,86 \\
0,25 & 2,44 & 1,89 & 1,59 & 1,03 \\
0,50 & 2,26 & 2,18 & 1,99 & 1,15 \\
2,00 & 2,18 & 2,15 & 1,46 & 1,33 \\
\hline \hline
\end{tabular}

\subsubsection{Teor de fósforo nas folhas}

Os teores de fósforo nas folhas de girassol em função das doses de boro aplicadas nos vasos e das fases de aplicação do estresse hídrico, estão contidos nas Figuras 27 e 28, respectivamente.

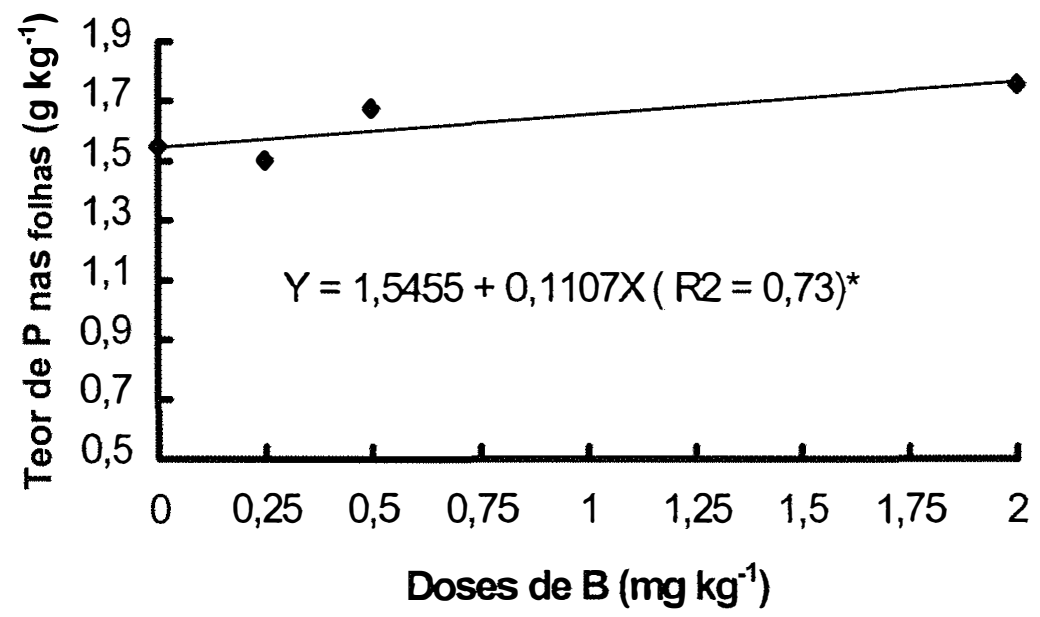

Figura 27. Teor de fósforo nas folhas de girassol, no início do florescimento, em função das doses de boro aplicadas no solo.

As doses de boro apresentaram efeito significativo e crescente nos teores de fósforo nas folhas, ajustando-se a equação do primeiro grau. O maior 
teor nas folhas de $1,76 \mathrm{~g} \mathrm{~kg}^{-1}$ de $P$, alcançado na dose mais elevada de $B$, é próximo daquele considerado adequado, na parte aérea de plantas de girassol citado por Baumgartener et al. (1986) que foi $1,8 \mathrm{~g} \mathrm{~kg}^{-1}$ de $P$, trabalhando em solução nutritiva. Entretanto, estes teores seriam considerado abaixo dos níveis críticos estabelecidos por Reuter (1986) que estavam ao redor de 2,2 e 2,4 g $\mathrm{kg}^{-1}$ de $P$.

Apesar do teor de $P$ nos tecidos serem considerados menores do que o nível crítico para a cultura, não foi constatado durante o ciclo da cultura, sintomas característicos da deficiência do nutriente. O teor de fósforo no solo, medido na época do florescimento foi em média $70 \mathrm{mg} \mathrm{dm}^{-1}$ de $P$, que é um teor alto para culturas anuais (Raij et al., 1997), bem como, especificamente para a cultura do girassol, segundo Quaggio \& Ungaro (1997).

Não é comum encontrar na literatura referências da interação entre o boro e o fósforo. Segundo Bartlett \& Picarelli (1973), trabalhando com alfafa em vaso, observaram um efeito contrário entre os dois elementos. Plantas que receberam altos niveis de boro continham menos $P$ que aquelas que não receberam boro, que é um comportamento contrário à observação constante na Figura 22. Leal et $a^{5}$., citado por Kabata-Pendias \& Pendias (1985), relataram que a absorção e distribuição do fósforo são dependentes da concentração de boro, já que o boro aumenta a imobilização do fósforo nas raízes. Para Robertson \& Loughman (1974), a deficiência de boro reduz a absorção de fosfato em raízes de plântulas de Vicia faba. Porém, segundo o mesmo autor, é improvável que o boro tenha um papel específico na absorção de fosfato; sendo mais provável que o balaço hormonal nas raízes de plantas deficientes afetem o transporte de fosfato.

\footnotetext{
5 LEAL, A.; GOMES, M.; SANCHEZ-RAYA, J.A.; RECALDE, L. Effect of boron absorptiom on accumulation and distribuition of phosphate, Le contrôle de l-adimentation des plantes cultivées: Budapest, 1972, $549 \mathrm{p}$.
} 
Ateeque et al. (1993), trabalhando com doses de fósforo na cultura do girassol a campo, observaram efeito positivo das doses de $P$ na elevação dos teores de boro na matéria seca e nos aquênios do girassol. O teor de boro na matéria seca variou de 10,63 a 18,80 $\mathrm{mg} \mathrm{kg}^{-1}$ quando os níveis de fósforo foram aumentados de 0 para $90 \mathrm{~kg} \mathrm{P}_{2} \mathrm{O}_{5}$ ha $^{-1}$.

Os teores de fósforo nas folhas, apresentaram efeito significativo $(p<0,01)$, em função das fases de aplicação do estresse hídrico (Figura 28). 0 tratamento COM, com $1,7 \mathrm{~g} \mathrm{~kg}^{-1}$ de $\mathrm{P}$ foi superior estatisticamente aos tratamentos sem estresse hídrico, que alcançaram em média $1,54 \mathrm{~g} \mathrm{~kg}^{-1}$ de $P$.

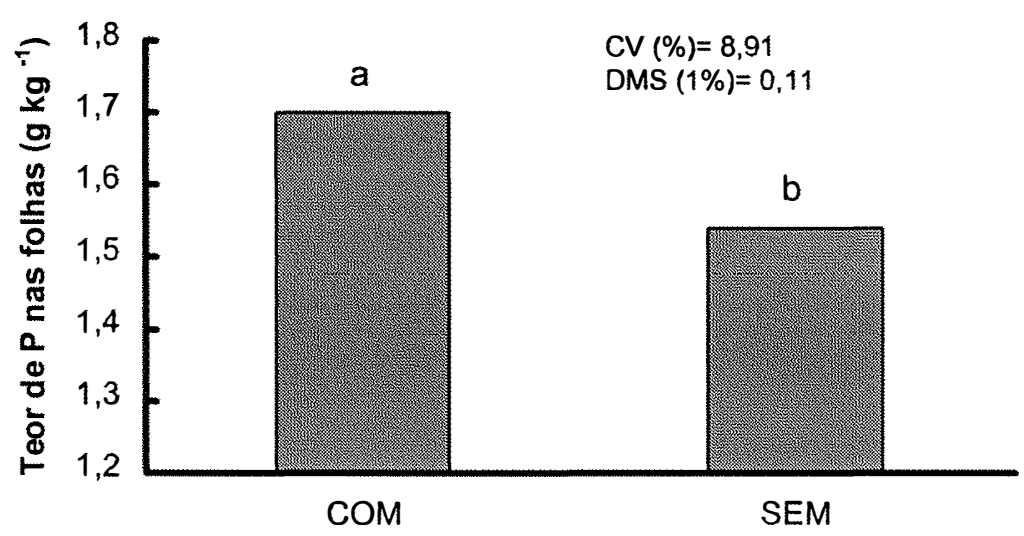

Fases de aplicação do estresse hídrico

Figura 28. Teor de fósforo nas folhas de girassol, no início do florescimento, nas fases de aplicação do estresse hídrico.

O maior teor de $P$ nas folhas do girassol no tratamento $C O M$, igualmente aos demais nutrientes, foi devido ao efeito de concentração do elemento nos tecidos, em função do menor desenvolvimento dessa plantas sob condições de restrição hídrica. Este comportamento, pode ser melhor constatado quando se avalia o teor nas folhas (Figura 28) e o conteúdo total do nutriente no girassol (Tabela 18). No apêndice 3 são apresentados os teores de fósforo nas folhas. 
Tabela 18. Conteúdo total de fósforo em plantas de girassol em resposta às doses de B aplicadas no solo.

\begin{tabular}{ccccccc}
\hline $\begin{array}{c}\text { Dose de B } \\
\left(\mathrm{mg} \mathrm{kg}^{-1}\right)\end{array}$ & SEM & \multicolumn{2}{c}{ IEA } & IFL & COM & $\begin{array}{c}\text { D.M.S } \\
\text { CV }\end{array}$ \\
\hline 0,00 & $0,095 \mathrm{a}$ & $0,092 \mathrm{a}$ & $0,071 \mathrm{~b}$ & $0,040 \mathrm{c}$ & 0,0184 & 9,39 \\
0,25 & $0,106 \mathrm{a}$ & $0,099 \mathrm{a}$ & $0,072 \mathrm{~b}$ & $0,044 \mathrm{c}$ & 0,0242 & 10,11 \\
0,50 & $0,126 \mathrm{a}$ & $0,104 \mathrm{ab}$ & $0,085 \mathrm{~b}$ & $0,057 \mathrm{c}$ & 0,0266 & 9,60 \\
2,00 & $0,125 \mathrm{a}$ & $0,115 \mathrm{a}$ & $0,079 \mathrm{~b}$ & $0,064 \mathrm{~b}$ & 0,0247 & 8,68
\end{tabular}

Média seguidas pelas mesmas letras na linha não diferem entre sí pelo teste de Tukey, ao nivel de $1 \%$ de probabilidade.

\subsubsection{Teor de Potássio nas folhas}

Os teores de potássio nas folhas de girassol em função das doses de boro aplicadas nos vasos (Figura 29), ao contrário do que ocorreu com o fósforo, decresceram em função das doses de boro aplicadas no solo $(p<0,05)$. $O$ modelo de regressão linear ajustou-se aos teores de $K$ nas folhas.

O maior teor do nutriente nas folhas $31,3 \mathrm{~g} \mathrm{~kg}^{-1}$ com zero de boro aplicado no solo, é considerado adequado (Blamey et al., 1987) que estabeleceram a concentração crítica de $24,0 \mathrm{~g} \mathrm{~kg}^{-1}$ de $\mathrm{K}$ na folha mais jovem e fisiologicamente madura ( $90 \%$ do rendimento máximo), trabalhando em solução nutritiva e Bergmann (1992) que estipulou como intervalo adequado 30 a $45 \mathrm{~g}$ $\mathrm{kg}^{-1}$ de K. Sfredo et al. (1983) encontraram $34,1 \mathrm{~g} \mathrm{~kg}^{-1}$ de $\mathrm{K}$, como o teor adequado para o girassol, no início do florescimento, em condições de campo. Borkert et al. (1997), citam que teores de $\mathrm{K}$ nas folhas abaixo de $18,8 \mathrm{~g} \mathrm{~kg}^{-1}$ causam queda no rendimento do girassol em condições de campo. 


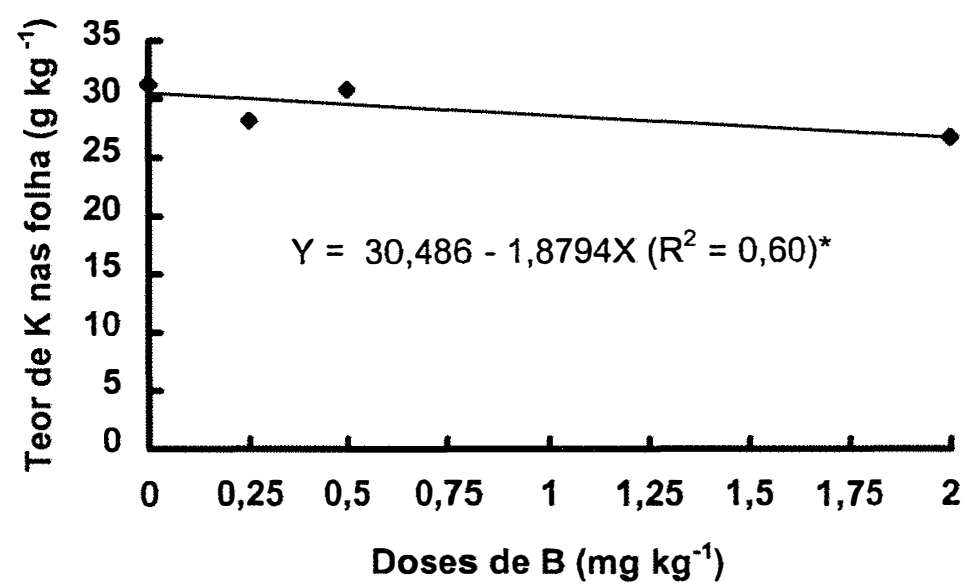

Figura 29. Teor de potássio nas folhas de girassol, no início do florescimento, em função das doses de boro aplicadas no solo.

Apesar do decréscimo do teor de $\mathrm{K}$ até a dose $2,0 \mathrm{mg} \mathrm{kg}^{-1}$ de boro aplicada no solo, não foi constatado durante o ciclo da cultura, sintomas característicos da deficiência do nutriente, em nenhuma fase da aplicação do estresse hídrico.

Conforme pode ser observado na Figura 29, o maior teor de $\mathrm{K}$ nas folhas ocorreu na menor dose de boro, quando as plantas apresentaram típicos sintomas de deficiências de boro nas folhas, caule, capitulos e pecíolos. Reeve \& Shive (1944), trabalhando com tomate em solução nutritiva, sugerem que plantas cultivadas em solos com teores relativamente baixos de $B$, podem não apresentar sintomas de deficiência do elemento, quando na presença de baixos teores de $\mathrm{K}$ no solo. Porém, podem ser severamente danificadas em condições de altos niveis de K. Resultado semelhante foi descrito por Wallace \& Bear (1949) que observaram folhas de alfafa com sintomas de deficiências de boro, com teor de $26 \mathrm{mg} \mathrm{kg}^{-1}$ de $B$, quando cultivada em solução com baixo teor de $B$ e $\mathrm{K}, 0,001$ e $10 \mathrm{mg} \mathrm{kg}^{-1}$, respectivamente e $10 \mathrm{mg} \mathrm{kg}^{-1}$ de $B$ com teor alto de $B$ e $\mathrm{K}, 5,0$ e $468 \mathrm{mg} \mathrm{kg}^{-1}$, respectivamente. No mesmo experimento, os teores de 
$B$ nas folhas aumentaram em resposta às doses crescentes de boro em solução. Woodruff et al. (1987), trabalhando com milho a campo, observaram redução da produção, no tratamento com a maior dose de potássio (382 kg ha-1 de $\mathrm{K}_{2} \mathrm{O}$ ) e sem a aplicação de boro no solo.

Apesar das considerações sobre a interação entre boro e potássio, provavelmente a deficiência de boro nas folhas do girassol, foi devido somente à sua carência. Várias plantas cultivadas em solos com elevados teores de $K$, absorvem grandes quantidade do nutriente, "consumo de luxo"; como no experimento com girassol conduzido por Sfredo et al. (1984). Assim, se altos teores de $\mathrm{K}$ nas folhas fossem detectados, a deficiência de boro nas menores doses de boro, poderia estar também associada ao teor de potássio no solo.

O teor de potássio no solo na época do florescimento, estava em média $8,7 \mathrm{mmol}_{\mathrm{c}} \mathrm{dm}^{-3}$ de $\mathrm{K}$, que é considerado um teor muito alto do nutriente, para culturas anuais (Raij et al., 1997), bem como, especificamente para a cultura do girassol (Quaggio \& Ungaro, 1997). Para Blamey et al. (1987), é pouco provável que solos com teores de potássio superiores a $2,5 \mathrm{mmol}_{\mathrm{c}} \mathrm{dm}^{-3}$, respondam à adubação potássica.

Os teores de potássio nas folhas apresentaram efeito significativo $(p<0,01)$, em função das fases de aplicação do estresse hídrico (Figura 30). Nas plantas do tratamento COM, foi observado o maior teor do elemento nas folhas com $30,8 \mathrm{~g} \mathrm{~kg}^{-1}$, superior as plantas do tratamento SEM, com média 27,5 $\mathrm{g} \mathrm{kg}^{-1}$ de $\mathrm{K}$.

O maior teor de $\mathrm{K}$ nas plantas do tratamento COM foi devido ao efeito de concentração do nutriente nos tecidos, em função do menor desenvolvimento das plantas. Por outro lado, observa-se na Tabela 19 que os conteúdos do nutriente nas plantas do tratamento COM, foram significativamente menores que aqueles dos tratamentos sem estresse hídrico até o florescimento. No apêndice 3 são apresentados os teores de potássio nas folhas. 


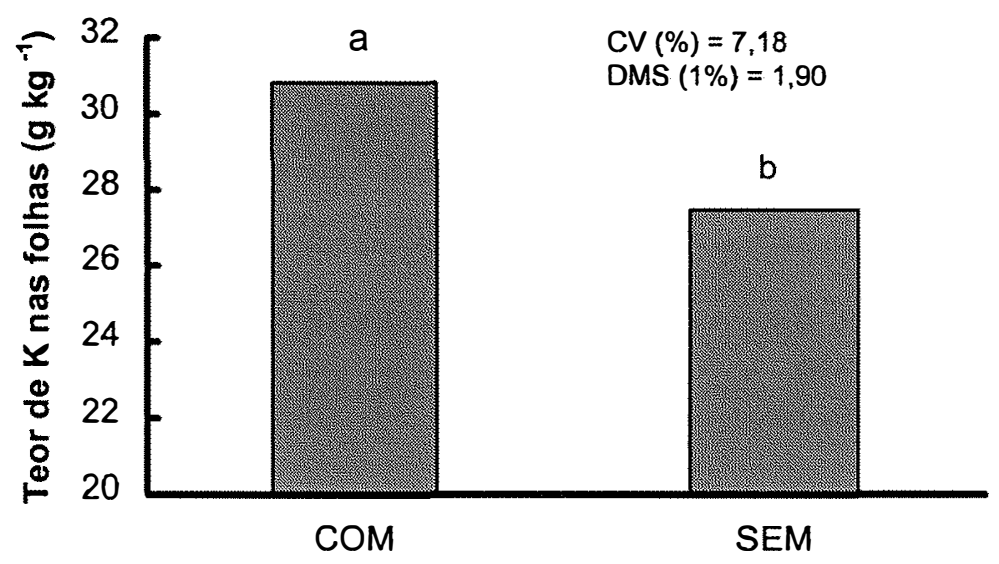

Fases de aplicação do estresse hídrico

Figura 30. Teor de potássio nas folha de girassol, no início do florescimento, nas fases de aplicação do estresse hídrico.

Tabela 19. Conteúdo total de potássio em plantas de girassol em resposta às doses de B aplicadas no solo.

\begin{tabular}{ccccccc}
\hline \hline $\begin{array}{c}\text { Dose de B } \\
\left(\mathrm{mg} \mathrm{kg}^{-1}\right)\end{array}$ & SEM & IEA & IFL & COM & $\begin{array}{c}\text { D.M.S } \\
\text { - }\end{array}$ & $\begin{array}{c}\text { CV } \\
(\%)\end{array}$ \\
\hline 0,00 & $2,05 \mathrm{a}$ & $1,85 \mathrm{a}$ & $1,49 \mathrm{a}$ & $0,78 \mathrm{~b}$ & 0,58 & 12,67 \\
0,25 & $1,88 \mathrm{a}$ & $1,73 \mathrm{ab}$ & $1,41 \mathrm{~b}$ & $0,85 \mathrm{c}$ & 0,35 & 7,97 \\
0,50 & $2,03 \mathrm{a}$ & $1,81 \mathrm{ab}$ & $1,53 \mathrm{~b}$ & $1,10 \mathrm{c}$ & 0,43 & 8,91 \\
2,00 & $1,92 \mathrm{a}$ & $1,60 \mathrm{~b}$ & $1,32 \mathrm{~b}$ & $0,97 \mathrm{c}$ & 0,28 & 6,56
\end{tabular}

Média seguidas pelas mesmas letras na linha não diferem entre sí pelo teste de Tukey, ao nível de $1 \%$ de probabilidade.

\subsubsection{Teor de cálcio nas folhas}

No teor de cálcio nas folhas do girassol a análise de variância revelou significância $(p<0,01)$ para a interação de doses de boro aplicadas no solo e fases de aplicação do estresse hídrico (Figura 31). 
As plantas do tratamento SEM apresentaram variação do teor de $\mathrm{Ca}$, ajustada à equação do segundo grau, aumentando o teor do nutriente nas folhas até o valor máximo de $13,1 \mathrm{~g} \mathrm{~kg}^{-1}$, nas plantas do tratamento COM, apesar da tendência de queda no teor de cálcio, não foi detectado efeito significativo. Bartlett \& Picarelli (1973) observaram redução significativa nos teores de Ca nos tecido de alfafa, com altos níveis de B aplicado no solo.

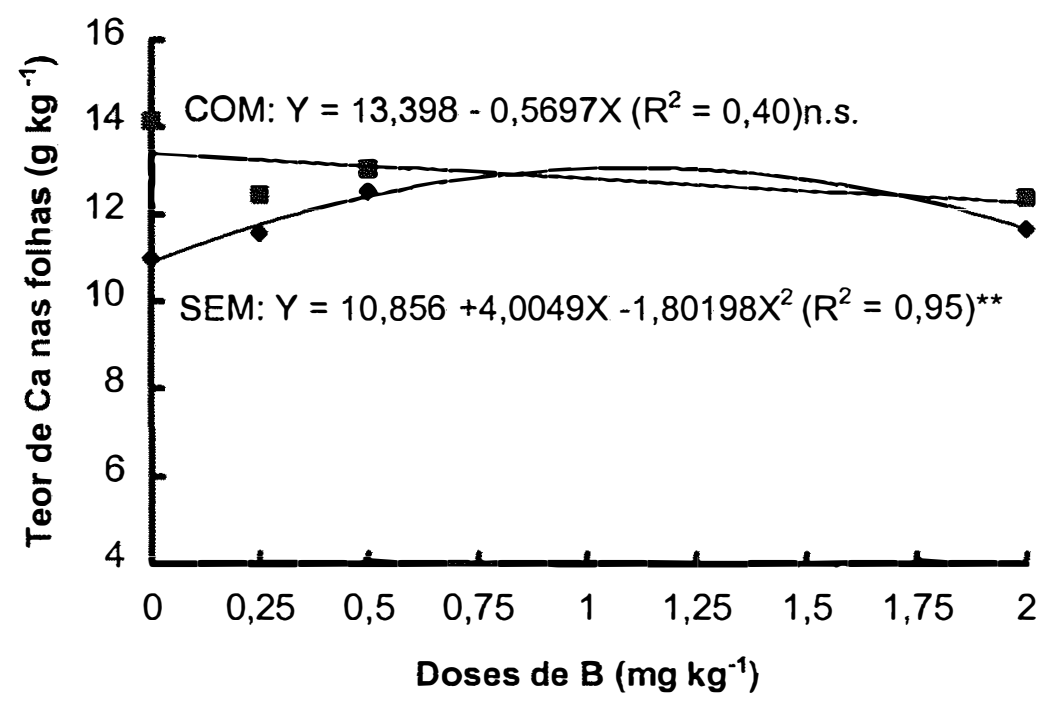

Figura 31. Teor de cálcio nas folha de girassol, no início do florescimento, em função das doses de boro aplicadas no solo e fases de aplicação do estresse hídrico.

Apesar das diferenças entre os tratamentos, os teores médios de Ca nas folhas de $13,0 \mathrm{~g} \mathrm{~kg}^{-1}$ no tratamento COM, e de $11,7 \mathrm{~g} \mathrm{~kg}^{-1}$ nos tratamentos sem estresse hídrico, ambos são considerados adequados para o girassol por Bergmann (1992), que estipulou a faixa adequada de Ca entre 8 e $20 \mathrm{~g} \mathrm{~kg}^{-1}$, em folhas completamente desenvolvidas, no início do florescimento. Blamey et al. (1978), trabalhando com boro e calagem/gesso em girassol a campo, 
encontraram que a concentração crítica de boro, das folhas maduras do terço superior da planta, no florescimento, estavam em torno de $17,0 \mathrm{~g} \mathrm{~kg}^{-1} \mathrm{de} C \mathrm{Ca}$.

Baumgartner et al. (1986) trabalhando com dose de cálcio e de boro, constataram que plantas normais apresentavam $16,4 \mathrm{~g} \mathrm{~kg}^{-1}$ de Ca na matéria seca da parte aérea de girassol, colhido aos 60 dias após a emergência das plantas, em casa de vegetação; ao passo que plantas com sintomas de colapso do capítulo, causado pela deficiência de cálcio e na mesma dose de boro, apresentaram teor de $4,6 \mathrm{~g} \mathrm{~kg}^{-1}$ de Ca nos tecidos.

Nas Tabelas 20 e Apêndice 3 encontram-se os conteúdos nas plantas e os teores de $\mathrm{Ca}$ em folhas, respectivamente. O menor conteúdo total de Ca nas plantas do tratamento COM, que ocorreu de modo geral em todas as doses de $B$ aplicadas no solo, foi devido ao menor desenvolvimento destas plantas.

Tabela 20. Conteúdo total de cálcio em plantas de girassol em resposta às doses de $B$ aplicadas no solo.

\begin{tabular}{ccccccc}
\hline $\begin{array}{c}\text { Dose de B } \\
\left(\mathrm{mg} \mathrm{kg}^{-1}\right)\end{array}$ & SEM & IEA & IFL & COM & $\begin{array}{c}\text { D.M.S } \\
\text { - }\end{array}$ & $\begin{array}{c}\text { CV } \\
(\%)\end{array}$ \\
\hline 0,00 & $0,657 \mathrm{a}$ & $0,653 \mathrm{a}$ & $0,558 \mathrm{a}$ & $0,356 \mathrm{~b}$ & 0,193 & 11,84 \\
0,25 & $0,858 \mathrm{a}$ & $0,684 \mathrm{a}$ & $0,635 \mathrm{a}$ & $0,359 \mathrm{~b}$ & 0,255 & 13,50 \\
0,50 & $0,916 \mathrm{a}$ & $0,811 \mathrm{a}$ & $0,755 \mathrm{a}$ & $0,414 \mathrm{~b}$ & 0,192 & 8,91 \\
2,00 & $0,897 \mathrm{a}$ & $0,748 \mathrm{ab}$ & $0,614 \mathrm{bc}$ & $0,425 \mathrm{c}$ & 0,257 & 12,83
\end{tabular}

Média seguidas pelas mesmas letras na linha não diferem entre sí pelo teste de Tukey, ao nível de $1 \%$ de probabilidade.

A relação ótima de Ca/B foi de 293 , no tratamento SEM, tomado como padrão de desenvolvimento. Este valor foi estimado com a dose de boro, correspondentes à $90 \%$ da maior produção de aquênios $\left(0,46 \mathrm{mg} \mathrm{kg}{ }^{-1}\right)$, aplicada nas respectivas equações de regressão dos teores de $\mathrm{Ca}$ e $\mathrm{B}$ nas folhas. Esta relação é superior a encontrada por Blamey et al. (1978), que 
estudando a relação de sintomas de deficiência de boro em girassol, em função da concentração de $\mathrm{B}$ e a razão $\mathrm{Ca} / \mathrm{B}$ nos tecidos, obtiveram a razão $\mathrm{Ca} / \mathrm{B}$ de 210 e a concentração de $B$ nas folhas de $57 \mathrm{mg} \mathrm{kg}^{-1}$, quando $5 \%$ dos capítulos estavam deformados. No trabalho, só foi observado deformação nos capítulos nas menores doses de boro no solo (Figuras 24 e 25).

\subsubsection{Teor de magnésio nas folhas}

A análise de variância do teor de magnésio nas folhas do girassol mostrou significância $(p<0,01)$ para a interação doses de boro aplicada no solo e fases de aplicação do estresse hídrico (Figura 32).

As equações de regressão ajustaram-se a modelos quadráticos com 1,7 e $1,4 \mathrm{~g} \mathrm{~kg}^{-1}$ de $\mathrm{Mg}$ nas folhas, nos pontos de máximo e mínimo, para os tratamentos SEM e COM, respectivamente. Baumgartner et al. (1986) trabalhando doses de boro e cálcio em girassol cultivado em solução nutritiva, observaram resultados semelhantes ao ocorrido nas plantas do tratamento COM.

Nas Tabelas 21, encontram-se os conteúdos totais de magnésio em plantas de girassol. O menor conteúdo total de $\mathrm{Mg}$ nas plantas do tratamento COM foi devido ao menor desenvolvimento destas. Os teores médios de $\mathrm{Mg}$ nas plantas do tratamento COM, estão, de modo geral, de acordo com o nível crítico de $1,8 \mathrm{~g} \mathrm{~kg}^{-1}$ de $\mathrm{Mg}$ (correspondendo a $90 \%$ do rendimento máximo), estabelecido por Blamey et al. (1987), trabalhando com girassol em casa-devegetação. Entretanto, Bergmann (1992) estabeleceu teores entre 3,0 a 8,0 g $\mathrm{kg}^{-1}$ de $\mathrm{Mg}$ como adequados para as folhas superiores e completamente desenvolvidas de girassol, colhido no início do florescimento, portanto, os valores observados no experimento, seriam inadequados para a cultura. 


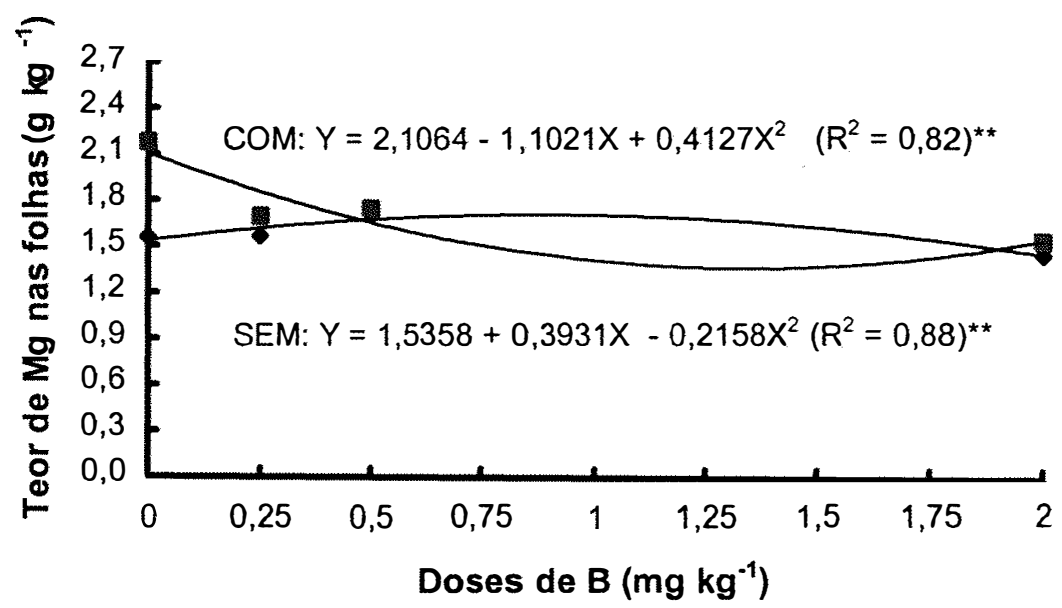

Figura 32. Teor de magnésio nas folhas de girassol, no início do florescimento, em função das doses de boro aplicada no solo e fases de aplicação do estresse hídrico.

Quaggio \& Ungaro (1997) recomendam para a cultura do girassol, que o teor de magnésio no solo deve ser elevado a um mínimo de $5 \mathrm{mmol}_{\mathrm{c}} \mathrm{dm}^{-3}$. $\mathrm{O}$ teor médio de magnésio no solo era de $8,7 \mathrm{mmol}_{\mathrm{c}} \mathrm{dm}^{-3}$, determinado no florescimento, portanto, de acordo com o recomendado para a cultura. Raij et al. (1997) consideram elevado este teor no solo, para as culturas anuais.

Tabela 21. Conteúdo total de magnésio em plantas de girassol em resposta às doses de $B$ aplicadas no solo.

\begin{tabular}{ccccccc}
\hline \hline $\begin{array}{c}\text { Dose de B } \\
\left(\mathrm{mg} \mathrm{kg}^{-1}\right)\end{array}$ & SEM & IEA & IFL & COM & D.M.S & CV \\
0,00 & $0,097 \mathrm{a}$ & $0,091 \mathrm{a}$ & $0,079 \mathrm{ab}$ & $0,055 \mathrm{~b}$ & 0,026 & 11,06 \\
0,25 & $0,109 \mathrm{a}$ & $0,099 \mathrm{ab}$ & $0,086 \mathrm{~b}$ & $0,049 \mathrm{c}$ & 0,020 & 7,70 \\
0,50 & $0,129 \mathrm{a}$ & $0,114 \mathrm{a}$ & $0,098 \mathrm{a}$ & $0,056 \mathrm{~b}$ & 0,034 & 11,59 \\
2,00 & $0,113 \mathrm{a}$ & $0,093 \mathrm{a}$ & $0,077 \mathrm{ab}$ & $0,053 \mathrm{~b}$ & 0,039 & 15,44 \\
\hline
\end{tabular}

Média seguidas pelas mesmas letras na linha não diferem entre sí pelo teste de Tukey, ao nível de $1 \%$ de probabilidade. 


\subsubsection{Teor de zinco nas folhas.}

O teor de zinco nas folhas, variaram significativamente $(p<0,01)$ em função das fases de aplicação do estresse hídrico (Figura 33). Em contraste aos demais nutrientes avaliados, nas plantas do tratamento COM, o menor teor do nutriente nas folhas, $44,7 \mathrm{mg} \mathrm{kg}^{-1}$, foi significativamente menor do que nas plantas dos tratamentos SEM, com teor médio de 53,9 de $\mathrm{mg} \mathrm{kg}^{-1}$.

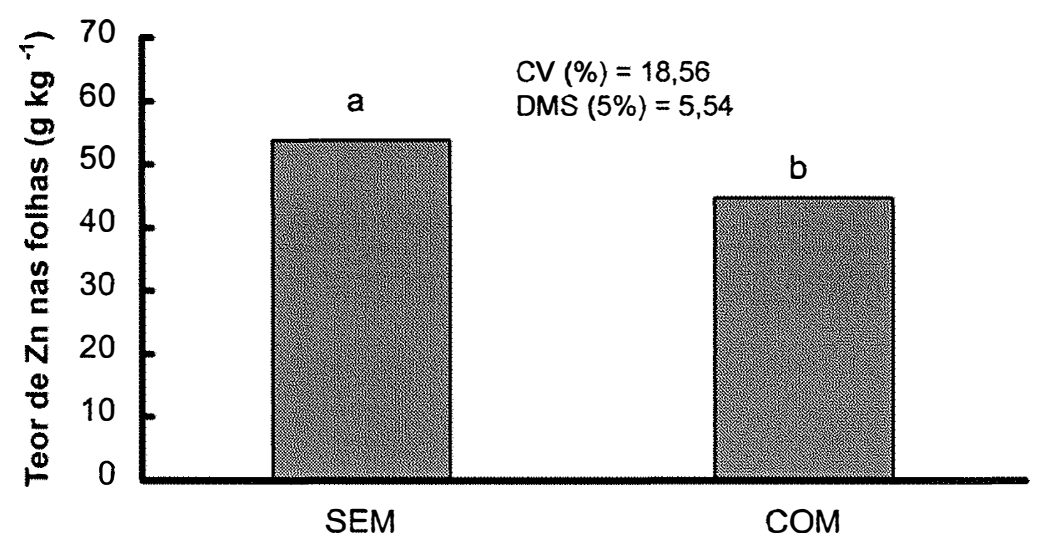

Fases de aplicação do estresse hídrico

Figura 33. Teor de zinco nas folhas de girassol, no início do florescimento, nas fases de aplicação do estresse hídrico.

Embora tenha havido diferenças estatísticas entre o teor nas folhas dos tratamentos COM e SEM, estes são considerados adequado para Bergmann (1992) que estabeleceu a faixa de 30 a $80 \mathrm{mg} \mathrm{kg}^{-1}$ de $\mathrm{Zn}$, como adequado no girassol. Baumgartner et al. (1986) estabeleceram $52 \mathrm{mg} \mathrm{kg}^{-1}$ de $\mathrm{Zn}$, como o teor adequado na parte aérea de girassol, cultivado em casa de vegetação. Machado (1979) determinou faixa ótima um pouco menor, entre 33 e $44 \mathrm{mg} \mathrm{kg}^{-1}$ de $\mathrm{Zn}$ nas folhas no início do florescimento. Sfredo \& Sarruge (1990) 
encontraram o teor de $36 \mathrm{mg} \mathrm{kg}^{-1}$ de $\mathrm{Zn}$ nas folhas, no início de florescimento, a campo, como adequado para fins de diagnose foliar.

Malavolta et al. (1997) informa que o boro parece estimular a absorção radicular de zinco. Entretanto, não foi observado efeito das doses de boro aplicadas no solo, no teor de zinco nas folhas do girassol.

\subsubsection{Teor de manganês nas folhas}

A análise de variância do teor de manganês nas folhas do girassol mostrou haver interação significativa entre doses de boro aplicadas no solo e fases de aplicação do estresse hídrico (Figura 34). O modelo de regressão quadrático ajustou-se aos teores de $\mathrm{Mn}$ obtidos nas plantas do tratamento SEM, enquanto o tratamento COM não foi influenciado pelas doses de boro.

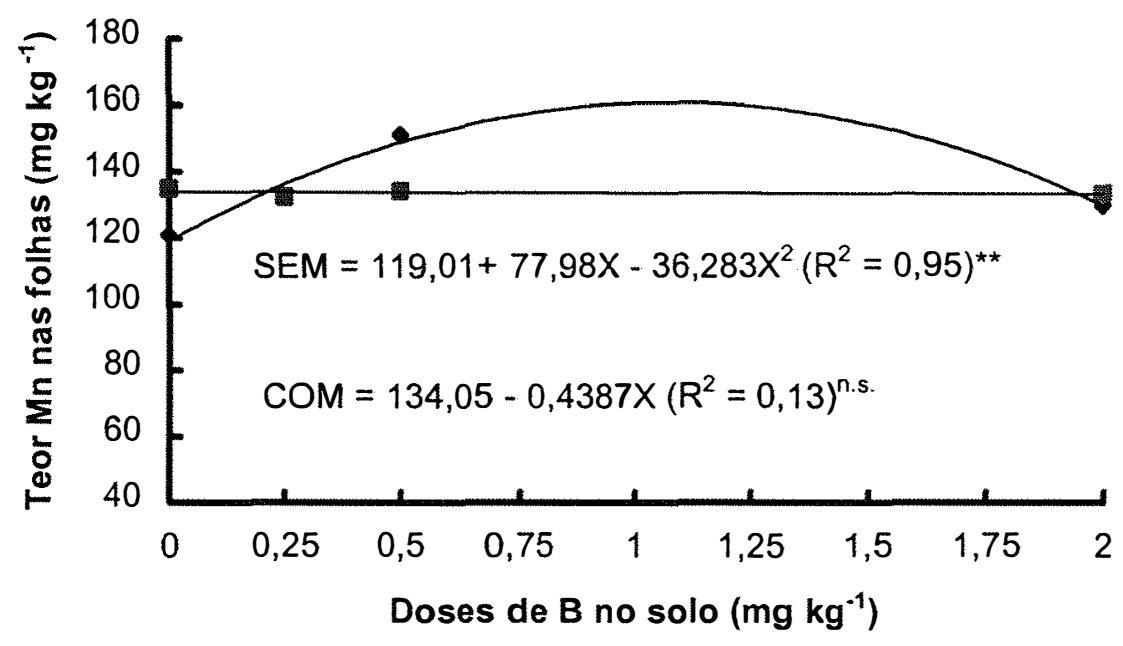

Figura 34. Teor de manganês nas folhas de girassol, no início do florescimento, em função das doses de boro aplicada no solo e fases de aplicação do estresse hídrico.

O teor médio de manganês nas folhas de girassol nos tratamentos SEM e COM, foi de $133 \mathrm{mg} \mathrm{kg}^{1}$. Sfredo \& Sarruge (1990) encontraram teores de 
manganês nas folhas de girassol, na faixa de 180 a $220 \mathrm{mg} \mathrm{kg}^{-1}$ de $\mathrm{Mn}$, como adequados para fins de diagnose foliar, colhidas no início de florescimento, a campo.

Estudos desenvolvidos por Bansal \& Nayyar (1995), encontraram teor bem menor, de $39 \mathrm{mg} \mathrm{kg}^{1}$ de $\mathrm{Mn}$, como sendo o nivel critico para a folha terminal mais jovem e madura de girassol, cultivado em casa-de-vegetação. Por outro lado, Blamey et al. (1986), indicam que o girassol acumula nos tricomas o excesso de manganês oriundo dos tecidos vizinhos, em forma metabolicamente inativa, possivelmente como óxidos altamente insolúveis. No mesmo estudo, foi calculada a concentração crítica de $2205 \mathrm{mg} \mathrm{kg}^{-1}$ de Mn nas folhas superiores, colhido no estádio $R_{2}$, correspondente ao teor tóxico para o girassol ( $90 \%$ da produção máxima de matéria seca).

\subsubsection{Teor de ferro nas folhas}

O teor de ferro nas folhas foram significativamente afetado pelas doses de boro aplicadas no solo $(p<0,01)$. A análise de regressão ajustou modelo quadrático para teor do nutriente nas folhas (Figura 35).

O teor médio de ferro nas folhas de $153 \mathrm{mg} \mathrm{kg}^{-1}$ se enquadra na faixa de 153 a $227 \mathrm{mg} \mathrm{kg}^{-1}$ determinada por Machado (1979) e abaixo daquela obtida por Sfredo (1986) de 224 a $257 \mathrm{mg} \mathrm{kg}^{-1}$, em folhas de girassol, no início de florescimento, a campo. Sfredo \& Sarruge (1990) estipularam $200 \mathrm{mg} \mathrm{kg}^{-1} \mathrm{de} \mathrm{Fe}$ nas folhas, como o teor adequado para fins de diagnose foliar no início da floração. 


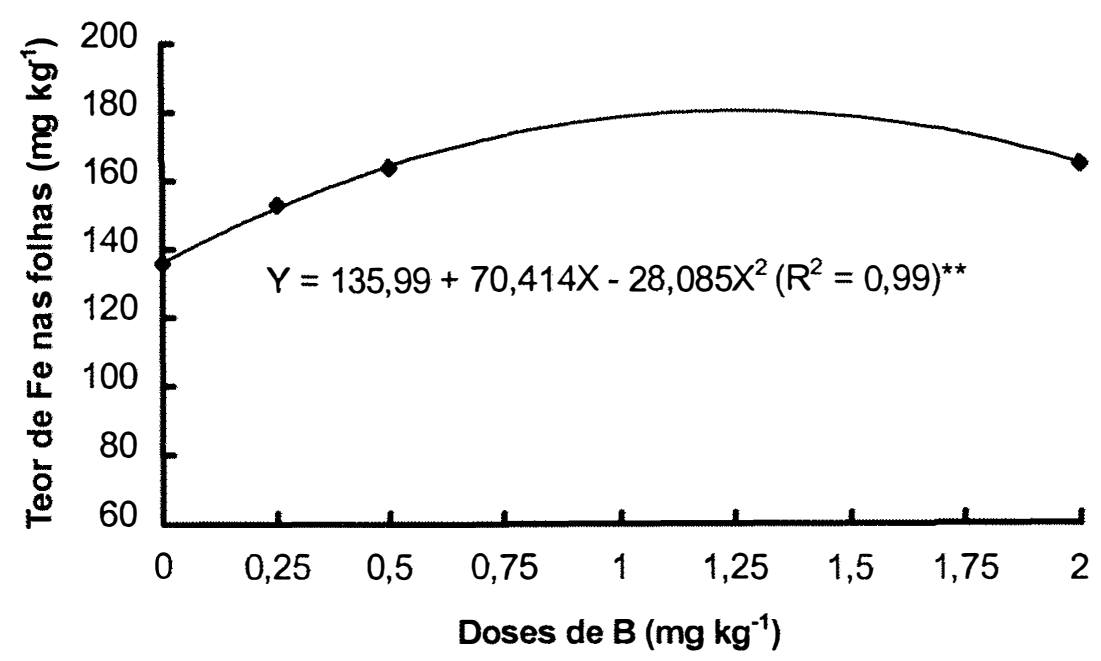

Figura 35. Teor de ferro nas folhas de girassol, no início do florescimento, em função das doses de boro aplicadas no solo.

\subsubsection{Teor de boro nos aquênios}

O teor médio de boro encontrado nos aquênios dos tratamentos SEM, COM, IFL e IEA foram de 5,$4 ; 5,4 ; 4,7$ e $5,1 \mathrm{mg} \mathrm{kg}^{-1}$, respectivamente. O teor crítico de $17 \mathrm{mg} \mathrm{kg}^{-1}$ de boro nos aquênios foi encontrado por Blamey et al. (1978) trabalhando com girassol a campo, quando 5\% dos capítulos apresentavam deformação,

Blamey (1977), estabeleceu os níveis críticos de boro de 10, 47 e 103 $\mathrm{mg} \mathrm{kg}^{-1}$ de $B$ nas folhas e de 11,16 e $18 \mathrm{mg} \mathrm{kg}^{-1}$ de $B$ nos aquênios, como teores deficiente, adequado e possivelmente excessivo para o crescimento normal do girassol, em condições de campo.

Os resultados evidenciam a diferença entre os teores de boro nos aquênios encontrados no experimento e os níveis críticos encontrados em outros trabalhos. Entretanto, devem ser consideradas as condições distintas entre os trabalhos, tais como a condução no campo e em casa-de-vegetação e o material genético avaliado. Deve ser observado entretanto, que o teor de 
boro nos aquênios, determinado no mesmo lote do híbrido ( $M$ 738) utilizado no experimento, foi de $6,2 \mathrm{mg} \mathrm{kg}^{-1}$ de $\mathrm{B}$, o qual é próximo dos obtidos neste experimento e bem abaixo daqueles citados por Blamey (1977) e Blamey et al. (1978), portanto, pode ser uma característica do material genético.

\subsubsection{Teor de boro no solo}

O teor de boro no solo ao final do experimento variaram significativamente $(p<0,01)$ em função das doses de boro aplicadas nos vasos, conforme Figura 36. O modelo de regressão quadrática ajustou-se aos teores do nutriente no solo.

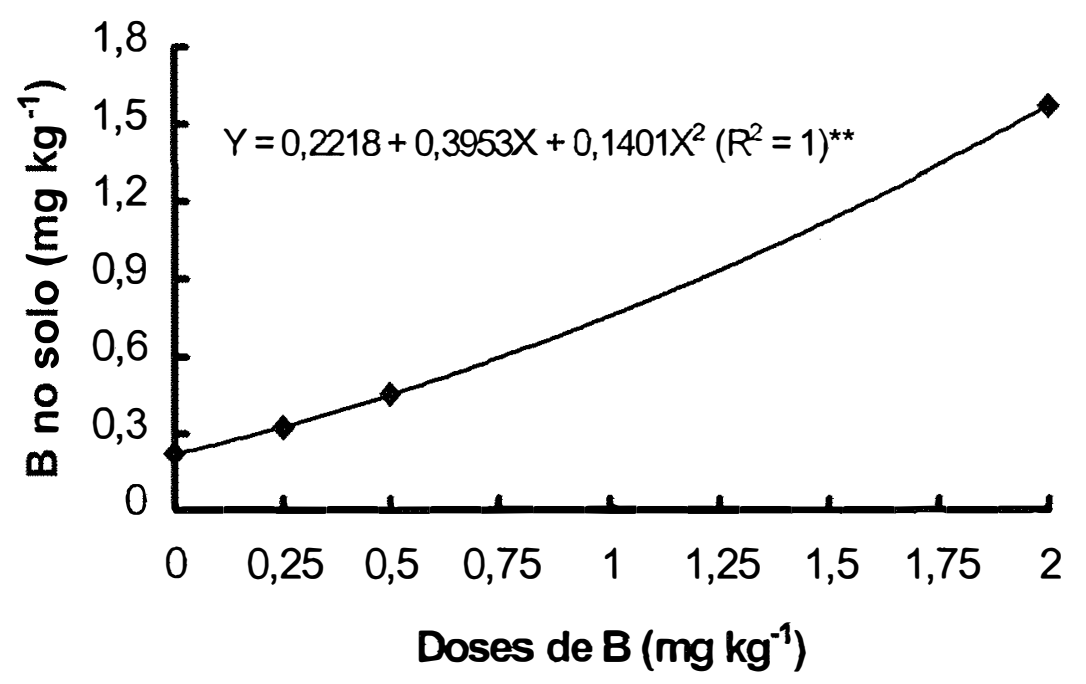

Figura 36. Teor de boro no solo ao final do experimento em função das doses de boro aplicadas no solo.

O teor de boro no solo após a colheita do girassol, 102 dias após a emergência das plantas, mantiveram-se próximos daqueles obtidos na época do florescimento (Tabela 5). Este comportamento evidencia a importância da interação entre o teor do nutriente no solo e a maior disponibilidade de água às 
plantas no desenvolvimento e na produção do girassol, conforme pode ser constatado nas Figuras 2, 5 e 10, em que as plantas do tratamento SEM, foram de modo geral, independente das doses de boro, superiores aos demais tratamentos.

Apesar dos teores elevados de boro no solo, em torno de $1,57 \mathrm{mg} \mathrm{kg}^{-1}$ de $B$, na maior dose de $B$, o teor encontrado nas folhas não foi elevado, conforme pode ser observado na Figura 36 , não sendo também observado sintomas de toxicidade do nutriente em nenhum tratamento. Apesar de não ter sido constatado toxicidade, Blamey et al. (1987) e Blamey et al. (1998) reportam que o girassol é tolerante a elevados teores de boro, e sintomas de toxicidade a campo não tem sido observados.

Avaliando-se o coeficiente de correlação entre os teores de boro no solo e nas folhas no conjunto das plantas dos tratamentos SEM, CQM, IFL e IEA $\left(0,69^{* *}\right)$, observa-se que apesar de significativo, não foi elevado. Isto se deve aos distintos teores de boro nas folhas para as plantas dos tratamentos SEM, IFL e IEA em relação as do tratamento COM, conforme pode ser observado na Figura 21.

Quando se analisa separadamente as plantas do tratamento COM O coeficiente aumenta para $0,84^{* *}$. Observa-se que nestas plantas, apesar da maior resposta às doses de boro aplicadas no solo, as mesmas não responderam com aumento de produção de aquênios ou desenvolvimento do girassol. Ou seja, não foi a absorção de boro, que poderia ser afetada pela menor taxa de transpiração, o fator limitante; mas sim a água, o fator preponderante para a expansão celular e desenvolvimento dessas plantas, como mostrado pelo menor potencial hídrico das folhas (Tabela 9).

Nas plantas do tratamento SEM o coeficiente de correlação foi de $0,65^{\star *}$, demonstrando que as condições hídricas e nutricionais propiciaram o melhor desenvolvimento do girassol e conseqüente diluição do boro nas folhas. 


\section{CONCLUSÕES}

1. O estresse hídrico afetou as variáveis produção de matéria seca total, da parte aérea, da raiz, produção de aquênios, número de aquênios, peso de 1000 aquênios e o teor e rendimento de óleo, em ordem crescente, os tratamentos estresse a partir do início do enchimento de aquênios (IEA), estresse a partir do início do florescimento (IFL) e estresse durante todo o ciclo (COM);

2 As doses de boro aplicadas no solo afetaram a produção de matéria seca total, da parte aérea, a altura de planta, a produção de aquênios, o número de aquênios, o peso de 1000 aquênios e o teor e rendimento de óleo;

3 As doses de boro aplicadas no solo afetaram os teores de macro e micronutrientes nas folhas de girassol;

4 A área foliar foi seriamente reduzida pelo estresse hídrico nos tratamentos estresse durante todo o ciclo (COM) e estresse a partir de início do florescimento (IFL);

5 A relação matéria seca das raizes e fitomassa total diminuiu ao longo do ciclo da cultura do girassol, em todos os tratamentos. No tratamento estresse hídrico durante todo o ciclo (COM) a queda foi mais acentuada; 
6 O estresse hídrico aplicado durante todo o ciclo da cultura (COM) reduziu a altura média das plantas. Os tratamentos estresse hídrico a partir de início do enchimento de aquênios (IEA), estresse hídrico a partir de início do florescimento (IFL) e o tratamento sem estresse hídrico (SEM) apresentaram a mesma altura de plantas;

7 A fase de aplicação do estresse hídrico a partir do início do florescimento seguido pela fase de aplicação do estresse hídrico a partir do início de enchimento de aquênios foram as épocas mais críticas à deficiência hídrica na cultura do girassol, afetando a produção de aquênios;

80 tratamento estresse hídrico durante todo o ciclo (COM) apresentou de modo geral, os maiores teores dos nutrientes nas folhas, entretanto, em função do menor desenvolvimento das plantas, proporcionou o menor acúmulo dos nutrientes nas plantas;

9 Os teores de boro nas folhas entre 42 e $43 \mathrm{mg} \mathrm{kg}^{-1}$, obtidos com a aplicação de 0,46 e $0,51 \mathrm{mg} \mathrm{kg}^{-1}$ de boro no solo, respectivamente, podem ser considerados adequados para a cultura do girassol. 


\section{REFERÊNCIAS BIBLIOGRÁFICAS}

ADRIANO, D.C. Trace elements in the terrestrial environment, New York: Springer-Verlag, 1986. 533p.

ALLEONI, L.R.F. Adsorção de boro em podzólico e latossolos paulistas. Piracicaba, 1996. 127p. Tese (Doutorado) - Escola Superior de Agricultura "Luiz de Queiroz", Universidade de São Paulo.

ASSENG, S.; RITCHIE, J.T.; SMUCKER, A.J.M.; ROBERTSON, M.J. Root growth and water uptake during water deficit and recovering in wheat. Plant and Soil, v.201, p.265-273, 1998.

ATEEQUE, M.; MALEWAR, G.U.; MORE, S.D. Influence of phosphorus and boron on yield and chemical composition of sunflower. Journal of the Indian Society of Soil Science, v.41, n.1, p.100-102, 1993.

BALLA, A.; OLIVEIRA, M.F.; LEITE, R.M.V.B.; CASTIGLIONI, V.B.R. Informes da avaliação de genótipos de girassol da rede oficial, 1995/96 e 1996, Londrina-PR: EMBRAPA - CNPSo, 1996. 62p.

BANSAL, R.L.; NAYYAR, V.K. Critical limit of manganese for sunflower (Helianthus annuus) in Ustochrepts. Indian Journal of Agricultural Sciences, v.65, n.3, p.205-206, 1995. 
BARTLETT, R.J.; PICARELLI, C.J. Availability of boron and phosphorus as affected by liming an acid potato soil. Soil Science, v.116, n.2, p.77-83, 1973.

BAUMGARTNER, J.G.; ANDREATTA, J.A.; FORMIGONI JÚNIOR, A. Efeito da deficiência de cálcio elou boro sobre o pedúnculo do capítulo do girassol. Pesquisa Agropecuária Brasileira, v.21, n.7, p.747-755, 1986.

BELHASSEN, E. Drought tolerance in higher plants. Dordrecht: Kluwer Academic Publishers, 1996. 104p.

BERGMANN, W. Nutritional disorders of plants: Development, visual and analytical diagnosis. Jena: Gustav Fischer Verlag, 1992. 742p.

BIRCH, E.B.; BLAMEY, F.P.C.; CHAPMAN, J. Boron nutrition of sunflower. Pretoria: Borax, 1981. 4p. (Sunflower E 1.1).

BLAMEY, F.P.C. Boron nutrition of sunflower (Helianthus annuus L.) on Avalon medium sandy loam. Soil and Fertilizers Abstract. v.40, n.12, p.745, 1977.

BLAMEY, F.P.C.; CHAPMAN, J. Differential response of two sunflower cultivars to boron fertilization, In: INTERNATIONAL SUNFLOWER CONFERENCE, 10., Surfers Paradise, 1982, Actas. Surfers Paradise, 1982, p.92-94.

BLAMEY, F.P.C.; CHAPMAN, J.; SMITH, M.F. Boron fertilization and soil amelioration effects on the boron nutrition on Spanish groundnuts. Crop Prod, v.10, p.143-146. 1981.

BLAMEY, F.P.C.; EDWARDS, D.G.; ASHER, C.J. Nutritional disorders of sunflower, Queensland: Department of Agriculture, University of Queensland, 1987.72p. 
BLAMEY, F.P.C.; JOYCE, D.C.; EDWARDS, D.G.; ASHER, C.J. Role of trichomes in sunflower tolerance to manganese toxicity. Plant and Soil, v.91, p.171-180, 1986.

BLAMEY, F.P.C.; MOULD, D.; CHAPMAN, J. Critical boron concentrations in plant tissue of two sunflower cultivars. Agronomy Journal, v.71, p.243-7, 1979.

BLAMEY, F.P.C.; MOULD, D.; NATHANSON, K. Relationships between B deficiency in sunflower and the $B$ and $\mathrm{Ca} / \mathrm{B}$ status of plant tissues in plant tissue of two sunflower cultivars. Agronomy Journal, v.70, p.376-380, 1978.

BLAMEY, F.P.C.; ZOLLINGER, R.K.; SCHNEITER, A.A. Sunflower production and culture. In: SCHNEITER, A.A. (Ed.) Sunflower technology and roduction. 2.ed. Madison: American Society of Agronomy, 1997, p.595-696. (Agronomy, 35).

BLEVINS, D.G.; LUKASZEWSKI. Boron in plant structure and function. Annual Review of Plant Physiology and Plant Molecular Biology, v.49, p.481$500,1998$.

BLOESCH, P. M.; BELL, L.C,; HUGHES, L.D. Adsorption and desorption of boron by goethite. Australian Journal Soil Research, 25, p.377-390, 1987.

BLUM, A.; ARKIN, G. F. Sorgum root growth and water-use as affected by water supply and growth duration. Field Crops, v.9, p.131-142, 1984.

BLUM, A. Crop responses to drought and the interpretation of adaptation. In: Belhassen, E. (Ed.) Drought tolerance in higher plants: genetical, physiological and molecular biological analysis. Dordrecht: Kluwer Academic, 1997. p.135-148. 
BORKERT, C.M.; SFREDO, G.J.; BOUÇAS FARIAS, J.R.; CASTRO, C.de.; SPOLADORI, C.L.; TUTIDA, F. Efeito residual da adubação potássica, sobre girassol e milho, em três diferentes latossolos roxos. Pesquisa Agropecuária Brasileira, v. 32, n. 12, p.1227-1234, 1997.

BOUÇAS FARIAS, J.R. Caracterização das respostas da cultura da soja aos elementos do clima. In: Resultados de pesquisa da EMBRAPA soja 1997. Londrina: EMBRAPA; Centro Nacional de Pesquisa de Soja. 1998, p.195202. (EMBRAPA-CNPSo. Documento, 118).

BOUMA, D. Effects of changes in boron nutrition on growth and development of subteranean clover. Australian Journal Biology Science. v.22, p.523-533, 1969.

BOYER, J.S. Leaf enlargement and metabolic rates in corn, soybean, and sunflower at various leaf water potential. Plant Physiology, v.46, p.233-235, 1970.

BOYER, J.S. Plant productivitv and environment. Science, v.218, p.443-448, 1982.

BROUWER, R. Distribuition of dry matter in the plant. Netherland Journal of Agricultural Science, v.10, n.5, 1962.

BUWALDA, J.G.; LENZ, F. Effects of cropping, nutrition and water supply on accumulation and distribuition of biomass and nutrients for apples trees on "M9" root systems. Physiology Plantarun, v.84, p.21-28, 1992.

CALLE-MANZANO, C.L.de. Carencia de boro en girasol. Madrid: Hojas Divulgadoras, n.7, p.1-12, 1985. 
CARTER, J.F. Sunflower science and technology, Madison: American Society of Agronomy, 1978. 505p. (Agronomy, 19).

CASAGRANDE, J.C. O boro em solos do Município de Piracicaba. Piracicaba, 1978. 122p. Dissertação (Mestrado) - Escola Superior de Agricultura "Luiz de Queiroz"; Universidade de São Paulo.

CASTIGLIONI, V.B.R.; BALLA, A.; CASTRO, C.; SILVEIRA, J.M. Fases de desenvolvimento da planta de girassol, Londrina: EMBRAPA, CNPSo, 1994. 24p. (EMBRAPA-CNPSo. Documento, 58)

CASTRO, C.; CASTIGLIONI, V.B.R.; BALLA, A.; CAMPOS LEITE, R.M.V.B.; KARAN, D.; MELLO, H.C.; GUEDES, L.C.A.; BOUÇAS FARIAS, J.R. A cultura do girassol, Londrina: EMBRAPA, CNPSo, 1996. 38p. (EMBRAPA-CNPSo. Circular Técnica, 13).

CHENG , S.F.; ZUBRISKI, J.S. Effects of nitrogen fertilizer on production of irrigated sunflower, plant uptake of nitrogen, and on water use. In: INTERNATIONAL SUNFLOWER CONFERENCE, 8., Minneapolis, 1978, Actas. Minneapolis, 1978, p.400-409.

CONNOR, D.J.; HALL, A.J. Sunflower physiology. In: SCHNEITER, A.A. (Ed.) Sunflower Technology and Production. 2.ed. Madison: American Society of Agronomy, 1997. p.113-182. (Agronomy, 35).

CONNOR, D.J.; SADRAS, V. O. Physiology of yield expression in sunflower. Field Crops Research, v.30, p. 333-389, 1992.

COX, W.J.; JOLLIFF, G.D. Growth and yield of sunflower and soybean under soil water deficits. Agronomy Journal, v.78, p.226-230, 1986. 
COX, W.J.; JOLLIFF, G.D. Crop water relations of sunflower and soybean under irrigated and dryland conditions. Crop Science, v.27, p.553-557, 1987.

ELLIS, B.G \& KNEZEK, B.D. Adsorption reactions of micronutrients in soils. In: MORTVEDT, J.J.; GIORDANO, P.M.; LINDSAY, L. (Ed.) Micronutrients in agriculture. Madison: Soil Science Society American, 1972, p.59-78.

ELLIS, B.G.; KNEZEK, B. D.; JACOBS, L.W. The movement of micronutrients in soils. In: KRAL, M.D. (Ed.) Chemical mobility and reactivity in soil systems. Madison: Soil Science Society American, 1983. p.109-122. (Special Publication, 11).

EMBRAPA -Serviço Nacional de Levantamento e Conservação de Solo. Manual de Métodos de Análise de Solo, Rio de Janeiro: SNLCS, 1979. $247 p$.

EVANS, C.M.; SPARKS, D.L. On chemistry and mineralogy of boron in pure and mixed systems: a review. Communications in Soil Science and Plant Analysis, v.14, n.9, p.827-846, 1983.

FITTER, A.H.; HAY, R.K.R. Environmental physiology of plants. 2.ed. London: Academic Press, 1987. 423p.

FLOWERS, T.J.; YEO, A.R. Solute transport in plants. Glasgow: Blackie Academic \& Professional, 1992. 176p.

FURLANI, A.M.C.; UNGARO, M.R.G.; QUAGGIO, J. A. Comportamento diferencial de genótipos de girassol: Eficiência na absorção e uso do boro. Revista Brasileira de Ciência do Solo, v.14, p.187-94, 1990.

GACHON, L. La cinétique de l'absorption des áléments nutritifs majeurs chez le tournesol. Annales Agronomiques, v.23, n.5, p.547-566, 1972. 
GIL-MARTINEZ, F. Elementos de fisiología vegetal: relaciones hídricas, nutrición mineral, transporte, metabolismo. Madrid: Ediciones MundiPrensa, 1995. cap. 7, p. 249-283.

GOLDBERG, S.; GLAUBIG, R. A. Boron adsorption on aluminum and iron oxide minerals. Soil Science Society American Journal, v.49, p.1374-1379, 1985.

GÓMEZ-ARNAU, J. El cultivo del girasol. Sevilla: Hojas Divulgadoras, n.20, p.1-31, 1988.

GONZALEZ-FERNÁNDEZ, P.; GARCIA BAUDÍN, C.; MADUEÑO ESQUINAS, T.; MELERO VARA, J.M. La deficiencia de boro en el girassol cultivado en España. In: CONFERENCIA INTERNACIONAL DE GIRASSOL, 11, Mar del Plata, 1985. Actas. Mar del Plata: ASAGIR, 1985, p.243-8.

GUPTA, U.C. Boron and its role in crop production. Boca Raton: CRC Press, 1993. $236 \mathrm{p}$.

GUPTA, U.C. \& MACLEOD, J. A. Influence of calcium and magnesium sources on boron uptake and yield of alfalfa and rutabagas as related to soil $\mathrm{pH}$. Soil Science, v.124, p.279-84, 1977.

GUPTA, U.C. \& MACLEOD, J. A. Plant and soil boron as influenced by soil pH and calcium sources on podzol soils. Soil Science, v.131, n.1, p.21-25, 1981.

GUTERRES, J.F.; BAMI, N.A.; COMIN, C.M.V. Nutrição e adubação. In: Girassol -indicações para o cultivo no Rio Grande do Sul. 2.ed. Porto Alegre: UFRGS, 1988. 66p. 
HALE, M.G.; ORCUTT, D.M. The physiology of plants under stress. New York: Wiley-Interscience, 1987. 205p.

HILL, E.W.; MORRILL, G.L. Boron calcium, and potassium interactions in spanish peanuts. Soil Science Society of America Proceedings, v.39, p.80-83, 1975.

HOCKING, P.J.; STEER, B.T. Uptake and partitioning of selected mineral elements in sunflower (Helianthus annuus L.) during growth. Field Crops Research, v.6, p. 93-107, 1983.

HOPKINS, W.G. The physiology of plants under stress. In: HOPKINS, W.G. (Ed.) Introduction to plant physiology. New York: John Wiley \& Sons, 1995. cap.21, p.423-443.

HSIAO, T. C.; BRADFORD, K.J. Physiological consequences of cellular water deficits. In: TAYLOR, H. M.; JORDAN, W.R.; SINCLAIR, T.R. (Ed.) Limitations to efficient water use in crop production. Madison: American Society of Agronomy, 1973, p.227-265.

HSIAO, T.C. Plant responses to water stress. Annual Review of Plant Physiology, v.24, p.519-570, 1973.

JONES, O.R. Yield, water-use efficiency, and oil concentration and quality of drayland sunflower grown in the southern high plains. Agronomy Journal, v.76, p.229-235, 1984.

JUNGK, A. Dynamics of nutrient movement at the soil-root interface. In: WAISEL,Y.; ESHEL, A.; KAFKAFI, U. (Ed.) Plant root: the hidden half. 2.ed. New York: Marcel Dekker, 1996. p.529-556. 
KABATA PENDIAS, A.; PENDIAS, $\mathrm{H}$. Trace elements in soil and plants. Boca Raton: CRC Press, 1985. 315p.

KASTORI, R.; PETROVIC, N. Effect of boron on nitrate reductase activity in young sunflower plants. Journal of Plant Nutrition, v.12, n.5, p.621-632, 1989.

KEREN, R.; GAST, R.G.; BAR-YOSEF, B. pH-dependent boron adsorption by Na-montmorillonite. Soil Science Society of America Journal, v.45, p.458, 1981.

KOCHIAN, L.V. Mechanisms of micronutriente uptake and translocation in plants. In: MORTVEDT, J.J.; COX.; F.R.; SHUMAN,L,M.; WELCH, R.M. (Ed.) Micronutrients in agriculture. 2.ed. Madison: Soil Science Society of America, 1991. Cap. 8, p.229-296.

KRAMER, P.J. Water deficits and plant growth. In: KRAMER, P.J. (Ed.) Water relations of plants. Florida: Academic Press, 1983. Cap.12, p. 342-389.

KRAMER, P.J.; BOYER, J.S. Roots and root systems. In: KRAMER, P.J.; BOYER, J.S. (Ed.) Water relations of plants and soils. San Diego: Academic Press, 1995. cap.5, p.115-166.

KUMAR, M.; DAS, D.K.; MANDAL, A.B. Transformations of boron in soil and its importance in plant nutrition. Environment \& Ecology, v.11, n.1, p.146-155, 1993.

LEHTO, T.; MÄLKÖNEN, E. Effects of liming and boron fertilization on boron uptake of Picea abies. Plant and Soil, v.163, p.55-64, 1994. 
LENOBLE, M.E.; BLEVINS, D.G.; MILES, R.J. Prevention of aluminum toxicity with supplemental boron. II. Stimulation of root growth in acidic, high aluminum subsoil. Plant Cell Environment, v. 19, p.1143-1148, 1996.

LINDSAY, W.L.; NORVELL, W.A. Development of a DTPA soil test for zinc, iron, manganese and copper. Soil Science Society of American Journal, v.42, p.421-428, 1978.

MACCHIA, M.; BENVENUTI, A.; BALDANZI, M. Temperature requirements during germination in sunflower. In: INTERNATIONAL SUNFLOWER CONFERENCE, 11., Mar del Plata, 1985. Actas. Mar del Plata: ASAGIR, 1985, p.93-97.

MACHADO, P.R. Absorção de nutrientes por duas variedades de girassol (Helianthus annuus L.) em função da idade e adubação em condições de campo. Piracicaba, 1979. 83p. Dissertação (Mestrado) - Escola Superior de Agricultura "Luiz de Queiroz", Universidade de São Paulo.

MAEDA, J.A.; UNGARO, M.R.J. Study of sunflower seed dormancy. In: INTERNATIONAL SUNFLOWER CONFERENCE, 11., Mar del Plata, 1985. Actas. Mar del Planta: ASAGIR, 1985, p.73-79.

MALAVOLTA, E.; VITTI, G.C.; OLIVEIRA, S. A. Avaliação do estado nutricional das plantas: principios e aplicações. 2.ed. Piracicaba: Associação Brasileira para Pesquisa da Potassa e do Fosfato, 1997. 319p.

MALIK, R.S.; DHANKAR, J.S.; TURNER, N.C. Influence of soil water deficits on root growth of cotton seedlings. Plant and Soil, v.53, p.109-112. 1979.

MARC, J. \& PALMER, J.H. Relationship between water potential and leaf and inflorescence initiation in Helianthus annuus. Physiology Plantarum, v.36, p.101-4, 1976. 
MARSCHNER, H. Mineral nutrition of higher plants. London: Academic Press, 1995. 889p.

MERRIEN, A. Physiologie du tournesol, Paris: CETION, 1992. 66p.

MIYAZAWA, M.; PAVAN, M.A.; BLOCH, M.F. Análise química de tecido vegetal. Londrina: IAPAR, 1992. 17p. (IAPAR. Circular, 74).

MORAGHAN, J.T.; MASCAGNI, Jr, H.J. Environmental and soil factors affecting micronutrient deficiencies and toxicities. In: MORTVEDT, J.J.; COX.; F.R.; SHUMAN,L,M.; WELCH, R.M. (Ed.) Micronutrients in agriculture. 2.ed. Madison: Soil Science Society of America, 1991. cap.11, p.371-425.

NILSEN, E.T.; ORCUTT, D.M. Physiology of plants under stress - abiotic factors. New York: John Wiley \& Sons, 1996. 689p.

O'TOOLE, J.C.; BLAND, W.L. Genotypic variation in crop plant root system. Advanced Agronomy, v.41, p.91-145, 1987.

OERTLI, J.J.; GRGUREVIC, E. Effect of $\mathrm{pH}$ on the absorption of boron by excised barley roots. Agronomy Journal, v.67, p.278-280, 1975.

OLIVEIRA, R.F. Desenvolvimento e análise de desempenho de um sensor de fluxo para avaliação de transpiração vegetal pelo método de balanço de calor. Piracicaba, 1997. 73p. Tese (Livre-docência) - Escola Superior de Agricultura "Luiz de Queiroz", Universidade de São Paulo.

PIMENTEL-GOMES, F. The use of Mitscherlich's law in the analysis of experiments with fertilizers. Biometrics, v. 9, p.498-516, 1953. 
POWER, P.P.; WOODS, W.G. The chemistry of boron and its speciation in plants. In: DELL, B.; BROWN, P.H.; BELL, R.W. (Ed.) Boron in soil and plants: Reviews. Dordrecht: Kluwer Academic Publishers, 1997, p.1-13.

QUAGGIO, J.A.; UNGARO, M.R.G. Girassol. In: RAIJ, B. VAN.; CANTARELLA, H.; QUAGGIO, J.A.; FURLANI, A.M.C. (Ed.) Recomendações de adubação e calagem para o Estado de São Paulo. 2.ed. Campinas: IAC, 1997. cap.19, p.198. (IAC - Boletim 100).

QUAGGIO, J.A.; UNGARO, M.R.G.; GALLO, P.B.; CANTARELLA, H. Sunflower response to lime and boron. In: INTERNATIONAL SUNFLOWER CONFERENCE, 11., Mar del Plata, 1985. Actas. Mar del Plata: ASAGIR, 1985, p.209-215.

RAIJ, B. van.; CANTARELLA, H.; QUAGgIO, J.A.; ABREU, C.A. de. Interpretação de resultados de análise de solo. In: RAIJ, B. VAN.; CANTARELLA, H.; QUAGGIO, J.A.; FURLANI, A.M.C. (Ed.) Recomendações de adubação e calagem para o Estado de São Paulo. 2.ed. Campinas: IAC, 1997. cap.4, p.8-13. (IAC - Boletim 100).

RAIJ, B. van.; QUAGGIO, J.A. Métodos de análise de solo para fins de fertilidade. Campinas: IAC, 1983. 31p. (IAC - Boletim Técnico, 81).

RAWSON, H.M.; CONSTABLE, G.A.; HOWE, G.N. Carbon production of sunflower cultivars in field and controlled environmenta. II Leaf growth. Australian Journal Plant Physiology, v.7, p.575-586, 1980.

REEVE, E.; SHIVE, J.W. Potassium-boron and calcium-boron relationships in plant nutrition. Soil Science, v.57, p.1-14, 1944. 
REUTER, D. J. Temperate and sub-tropical crops. In: REUTER, D.J.; ROBINSON, J.B. (Ed.) Plant analysis. Melbourne: Inkata Press, 1986. p.38-99.

REUTER, D. J.; EDWARDS, D.G.; WILHELM, N.S. Temperate and tropical crops. In: REUTER, D.J.; ROBINSON, J.B. (Ed.) Plant analysis. Melbourne: Inkata Press, 1997. p.83-278.

REYNOLDS, S.B.; SCAIFE, A.; TURNER, M.K. Efect of nitrogen form on boron uptake by cauliflower. Communications in Soil Science and Plant Analysis, v.18, n.9, p.1143-1154, 1987.

ROBELIN, M. Action et arrière-action de la sécheresse sur la croissance et la production du tournesol. Annales Agronomiques, v.18, n.6, p.579-599, 1967.

ROBERTSON, G.A.; LOUGHMAN, B.C. Modification of phosphate transport in Vicia faba by boron deficiency, growth regulators, and metabolic inhibitors. In: ZIMMERMANN, U.; DAINTY, J. (Ed.) Membrane transport in plants. New York: Springer-Verlag, 1974. p. 444-449.

RUY, V.M. Contribuição para o estudo do boro disponível em solos. Piracicaba, 1986. 104p. Dissertação (Mestrado) - Escola Superior de Agricultura "Luiz de Queiroz", Universidade de São Paulo.

SARRUGE, J.R. \& HAAG, H.P. Análise química em plantas. Piracicaba: ESALQ, 1974. 56p.

SCHILDWACHT, P.M. Changes in the osmotic potential of the root as factor in the decrease in the root-shoot ratio of Zea mays plants under water stress. Plant Soil, v.111, p.271-275, 1988. 
SCHNEITER, A.A.; MILLER, J.F. Description of sunflower growth stages. Crop Science, v.21, p.901-903, 1981.

SCHUSTER , C.E.; STEPHENSON, R.E. Sunflower as an indicator plant of boron deficiency in soil. Journal of the American Society of Agronomy, v.32, p.607-621, 1940.

SFREDO, G.J.; CAMPOS, R.J.; SARRUGE, J.R. Girassol: nutrição mineral e adubação. Londrina: EMBRAPA-CNPSo, 1984. 36p. (EMBRAPA-CNPSo. Circular técnica, 8).

SFREDO, G.J.; SARRUGE, J.R. Acúmulo de micronutrientes em plantas de girassol. Pesquisa Agropecuária Brasileira, v.25, n.4, p.499-503, 1990.

SFREDO, G.J.; SARRUGE, J.R.; HAAG, H.P. Absorção de nutrientes por duas cultivares de girassol (Helinthus annuus 1.), em condições de campo. I. Concentração de macronutrientes. Anais da Escola Superior de Agricultura "Luiz de Queiroz", v.40, p1135-1163, 1983.

SHARP, R.E.; DAVIES, W.J. Regulation of growth and development of plants growing with a restricted supply of water, In: JONES, H.G.; FLOWERS, T.J.; JONES, M.B. (Ed.) Plants Under Stress, Cambridge: University Press, 1989. p.71-93.

SHARP, R.E.; SILK, W.K.; HSIAO, T.C. Growth of the maize primary root at low water potentials. I. Spatial distribution of expansive growth. Plant Physiology, v.87, p.50-57, 1988.

SHELP, B.J. Physiology and biochemistry of boron in plant. In: GUPTA, U.C. (Ed.) Boron and its role in crop production, Boca Raton: CRC Press, 1993. 236p. 
SIONIT, N.; GHORASHY, S. R.; KHERADNAM, M. Effect of soil water potential on growth and yield of sunflower (Helianthus annuus L.). Journal of Agricultural Science, v. 81, p.113-116. 1973.

STEER, B.T.; LOW, A.; HOCKING, P.J. Nitrogen nutrition of sunflower (Helianthus annus L.): yield response of seven genotypes and interaction of heterosis with nitrogen supply. Field Crops Research, v.12, p.1-16, 1985.

TAIZ, L.; ZEIGER, E. Water balance of the plant. In: TAIZ, L.; ZEIGER, E (Ed.) Plant Physiology. 2 ed. Massachusetts: Sianauer Associats, 1998. 792p.

TAKAMI, S.; TURNER, N.C.; RAWSON, H.M. Leaf expansion of four sunflower (Helianthus annuus L.) cultivars in relation to water deficits. I. Patterns during plant development. Plant Cell Environment. v. 4, p.399-407, 1981.

TALHA, M.; OSMAN, F. Effect of soil water stress on water economy and oil composition in sunflower (Helianthus annuus L.). Journal of Agricultural Science, v. 84, p.49-56, 1975.

TURNER, N.C.; BEGG, J.E. Responses of pasture plants to water deficits. In: WILSON, J.R. (Ed.) Plant relations in pastures. East Melbourne: CSIRO, 1978. cap. 4 , p.50-66.

UNGARO, M,R,G, Recomendações técnicas para o cultivo do girassol, Correio Agrícola, n.2, p.314-318, 1981.

UNGER, P.W. Sunflower. In: STEWART, B. A. \& NIELSEN, D.R. (Ed.) Irrigation of agricultural crops, Madison: American Society of Agronomy, 1990. p.775-794, (Agronomy, 30). 
VASUDEVAN, S.N.; VIRUPAKSHAPPA, K.; VENUGOPAL, N.; BHASKAR, S. Response of sunflower (Helianthus annuus L.) to phosphorus, sulphur, micronutrients and humic acid under irrigated condition on red sandy-loam soil. Indian Journal of Agricultural Sciences, v.67, n.3, p.110-112, 1997.

VRANCEANU, A.V. El girassol, Madrid: Ediciones Mundi-Prensa, 1977. 379p.

WAISEL, Y.; ESHEL, A.; KAFKAFI, U. Plant root: the hidden half. 2. ed. New York: Marcel Dekker, 1996. 1002.

WALLACE, A.; BEAR, F.E. Influence of potassium and boron on nutrientelement balance in and growth of ranger alfalfa. Plant Physiology, v.24, p.664-680, 1949.

WEISS, E.A. Sunflower. In: WEISS, E.A. Oiseed crops, New York: Longman, 1983. cap. 9, p.402-62.

WELCH, R.M. Micronutrient Nutrition of Plants. In: CONGER, B.V. (Ed.) Plant Sciences, v.14, n.1, p.49-82, 1995.

WOODRUFF, J.R.; MOORE, F.W.; MUSEN, H.L. Potassium, boron, nitrogen, and lime effects on corn yield and earleaf nutrient concentrations. Agronomy Journal, v.79, p.520-524, 1987. 


\section{APÊNDICE 1}

Equações de regressão ajustadas para a produção de matéria seca total em g/vaso (Y) como variável dependente das doses de boro aplicadas no solo em $\mathrm{mg} \mathrm{kg}^{-1}(\mathrm{X})$, nos períodos de coletas das plantas.

Períodos (dias)

\begin{tabular}{lcc}
\hline \hline & \multicolumn{2}{c}{ Períodos (dias) } \\
\cline { 2 - 3 } & Equações & $\mathrm{R}^{2}$ \\
\hline Tratamentos & $\mathrm{Y}=95,393+51,206 \mathrm{X}-20,127 \mathrm{X}^{2}$ & 0,98 \\
SEM/IEA/IFL & $\mathrm{Y}=31,502+47,813 \mathrm{X}-17,756 \mathrm{X}^{2}$ & 0,97 \\
COM & $\mathrm{P}$ & \\
\hline
\end{tabular}

\section{$54^{*}$}

\begin{tabular}{lll}
\hline SEM/IEAJIFL & $Y=208,91+91,798 X-39,114 X^{2}$ & 0,99 \\
COM & $Y=84,962+69,026 X-28,009 X^{2}$ & 0,93
\end{tabular}

\section{$65^{*}$}

\begin{tabular}{llc}
\hline SEM/IEA/IFL & $Y=221,17+163,96 X-63,029 X^{2}$ & 0,99 \\
COM & $Y=102,2+66,932 X-23,859 X^{2}$ & 0,79 \\
\hline
\end{tabular}

\begin{tabular}{lll}
\hline SEM/IEA & $Y=292,37+180,18 X-71,49 X^{2}$ & 0,98 \\
COM & $Y=112,94+89,256 X-35,377 X^{2}$ & 0,99 \\
IFL & $Y=221,24+151,23 X-59,623 X^{2}$ & 0,91 \\
\hline
\end{tabular}

\section{$89^{\star \star \star}$}

\begin{tabular}{lll}
\hline SEM & $Y=302,89+223,53 X-91,281 X^{2}$ & 0,99 \\
COM & $Y=123,05+86,297 X-32,465 X^{2}$ & 0,95 \\
IEA & $Y=269,78+255,23 X-104,81 X^{2}$ & 0,96 \\
IFL & $Y=260,65+154,38-70,461 X^{2}$ & 0,97 \\
\hline
\end{tabular}

* Equação de regressão obtida com base na produção de matéria seca total de 12 e 4 plantas dos tratamentos SEM/IEA/IFL e COM, respectivamente;

** Equação de regressão obtida com base na produção de matéria seca total de 8,4 e 4 plantas dos tratamentos SEM/IEA, COM e IFL, respectivamente;

*** Equação de regressão obtida com base na produção de matéria seca total de 4 plantas em cada tratamento: SEM, COM, IEA e IFL. 


\section{APÊNDICE 2}

Produção de matéria seca de raiz em função das doses de boro aplicadas no solo e fases de aplicação do estresse hídrico.

\begin{tabular}{|c|c|c|c|c|c|}
\hline \multirow{3}{*}{ Tratamentos } & \multicolumn{4}{|c|}{ Doses de boro $\left(\mathrm{mg} \mathrm{kg}^{-1}\right)$} & \multirow{3}{*}{ Média } \\
\hline & 0,00 & 0,25 & 0,50 & 2,00 & \\
\hline & \multicolumn{4}{|c|}{-g/planta - - - } & \\
\hline SEM & 10,80 & 11,02 & 12,03 & 9,74 & $10,90 a$ \\
\hline IEA & 10,60 & 10,50 & 10,90 & 10,47 & $10,62 \mathrm{a}$ \\
\hline IFL & 9,20 & 8,64 & 9,00 & 9,10 & $8,98 \mathrm{~b}$ \\
\hline COM & 3,71 & 3,31 & 3,40 & 3,90 & $3,58 \mathrm{c}$ \\
\hline Média & 8,58 & 8,37 & 8,83 & 8,30 & \\
\hline
\end{tabular}

$\overline{\text { Médias seguidas pelas mesmas letras na coluna não diferem entre si pelo teste de Tukey, ao }}$ nivel de $1 \%$ de probabilidade. 


\section{APÊNDICE 3}

Teores de macronutrientes nas folhas de girassol em resposta às doses de $B$ aplicada no solo, aos 65 e 89 dias após a emergência das plantas.

\begin{tabular}{|c|c|c|c|c|}
\hline Dose B & SEM & IEA & IFL & $\mathrm{COM}$ \\
\hline & \multicolumn{4}{|c|}{ Nitrogênio aos 65 dias } \\
\hline 0,00 & 39,7 & 42,8 & 42,2 & 47,7 \\
\hline 0,25 & 43,6 & 45,6 & 42,8 & 44,4 \\
\hline 0,50 & 43,1 & 44,3 & 43,2 & 43,0 \\
\hline \multirow[t]{2}{*}{2,00} & 42,1 & 44,2 & 42,3 & 48,1 \\
\hline & \multicolumn{4}{|c|}{ Nitrogênio aos 89 dias } \\
\hline 0,00 & 39,7 & 42,8 & 42,2 & 47,7 \\
\hline 0,25 & 43,6 & 45,6 & 42,8 & 44,7 \\
\hline 0,50 & 43,1 & 44,3 & 43,2 & 43,0 \\
\hline \multirow[t]{2}{*}{2,00} & 42,1 & 44,2 & 42,3 & 48,1 \\
\hline & \multicolumn{4}{|c|}{ Fósforo } \\
\hline 0,00 & 1,50 & 1,52 & 1,48 & 1,60 \\
\hline 0,25 & 1,46 & 1,53 & 1,40 & 1,54 \\
\hline 0,50 & 1,69 & 1,54 & 1,49 & 1,78 \\
\hline \multirow[t]{2}{*}{2,00} & 1,69 & 1,76 & 1,46 & 1,87 \\
\hline & \multicolumn{4}{|c|}{ Potássio } \\
\hline 0,00 & 32,30 & 30,65 & 31,05 & 31,13 \\
\hline 0,25 & 25,75 & 26,67 & 27,45 & 29,35 \\
\hline 0,50 & 27,23 & 26,73 & 27,03 & 34,53 \\
\hline \multirow[t]{2}{*}{2,00} & 25,90 & 24,53 & 24,53 & 28,35 \\
\hline & \multicolumn{4}{|c|}{ Cálcio } \\
\hline 0,00 & 10,37 & 10,80 & 11,65 & 14,15 \\
\hline 0,25 & 11,75 & 10,52 & 12,40 & 12,45 \\
\hline 0,50 & 12,27 & 11,97 & 13,30 & 13,05 \\
\hline \multirow[t]{2}{*}{2,00} & 12,12 & 11,45 & 11,40 & 12,37 \\
\hline & \multicolumn{4}{|c|}{ Magnésio } \\
\hline 0,00 & 1,53 & 1,50 & 1,65 & 2,18 \\
\hline 0,25 & 1,50 & 1,53 & 1,68 & 1,70 \\
\hline 0,50 & 1,73 & 1,67 & 1,73 & 1,75 \\
\hline 2,00 & 1,53 & 1,43 & 1,43 & 1,55 \\
\hline
\end{tabular}




\section{APÊNDICE 4}

Teor de boro nas folhas de girassol em resposta às doses de $B$ aplicada no solo, aos 65 dias após a emergência das plantas.

\begin{tabular}{ccccc}
\hline Dose B & SEM & IEA & IFL & COM \\
& & & & \\
\hline 0,00 & 16,35 & 15,80 & 17,90 & 21,40 \\
0,25 & 32,65 & 34,37 & 35,50 & 37,45 \\
0,50 & 44,17 & 44,70 & 43,60 & 46,75 \\
2,00 & 46,27 & 45,17 & 50,65 & 59,17 \\
\hline \hline
\end{tabular}

